
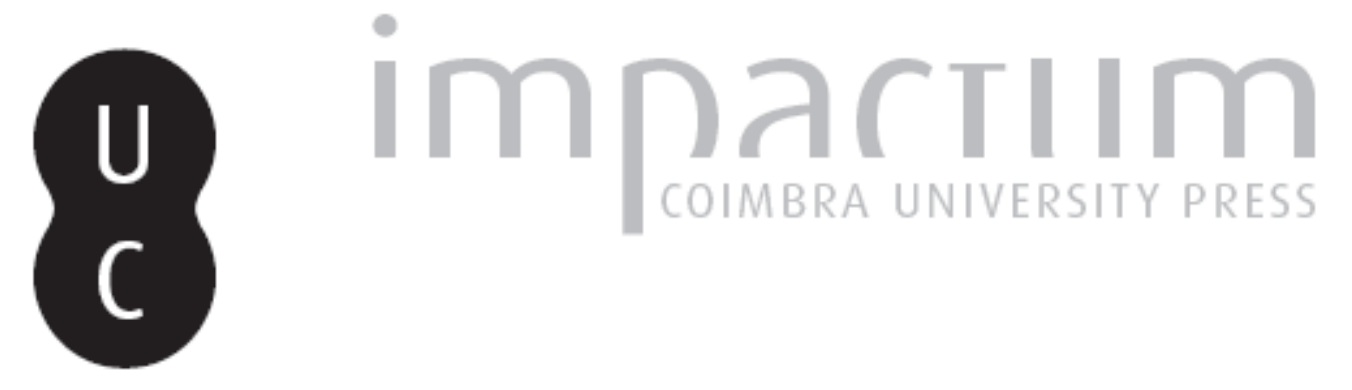

\title{
A villa romana do Alto do Cidreira: (Cascais)
}

Autor(es): $\quad$ Nolen, Jeannette U. Smit

Publicado por: Imprensa da Universidade de Coimbra

URL persistente:

URl:http://hdl.handle.net/10316.2/45585

DOI:

DOI:https://dx.doi.org/10.14195/1647-8657_27_2

Accessed : $\quad$ 26-Apr-2023 11:55:05

A navegação consulta e descarregamento dos títulos inseridos nas Bibliotecas Digitais UC Digitalis, UC Pombalina e UC Impactum, pressupõem a aceitação plena e sem reservas dos Termos e Condições de Uso destas Bibliotecas Digitais, disponíveis em https://digitalis.uc.pt/pt-pt/termos.

Conforme exposto nos referidos Termos e Condições de Uso, o descarregamento de títulos de acesso restrito requer uma licença válida de autorização devendo o utilizador aceder ao(s) documento(s) a partir de um endereço de IP da instituição detentora da supramencionada licença.

Ao utilizador é apenas permitido o descarregamento para uso pessoal, pelo que o emprego do(s) título(s) descarregado(s) para outro fim, designadamente comercial, carece de autorização do respetivo autor ou editor da obra.

Na medida em que todas as obras da UC Digitalis se encontram protegidas pelo Código do Direito de Autor e Direitos Conexos e demais legislação aplicável, toda a cópia, parcial ou total, deste documento, nos casos em que é legalmente admitida, deverá conter ou fazer-se acompanhar por este aviso.

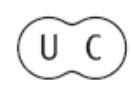


FACULDADE DE LETRAS

INSTITUTO DE ARQUEOLOGIA

\title{
CONIMBRIGA
}

\author{
VOLUME XXVII
}

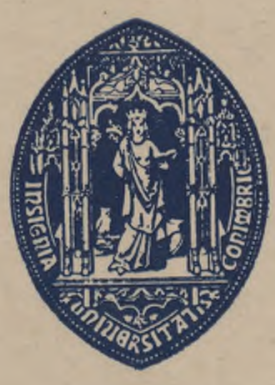

UNIVERSIDADE DE COIMBRA

1988 
JeANNETTE U. SMit NOLEN

Colaboradora do Museu Monográfico de Conimbriga

A VILLA ROMANA DO ALTO DO CIDREIRA (CASCAIS)

- OS MATERIAIS

Conimbriga, XXVII (1988), p. 61-140

Resumo: Publicam-se os materiais encontrados numa pecmena villa a norte de Cascais (com excepção dos achados metálicos). Dado que o sítio, no topo de uma colina, sofreu forte erosão e foi ainda lavrado durante séculos, não se pôde registar qualquer estratigrafía significativa. Decidiu-se, por isso, apresentar os materiais sob a forma de um catálogo, de modo a que o leitor possa ter uma visão global dos diferentes materiais, das suas formas e tipos e, sobretudo, das suas quantidades relativas, nesta villa. As cerâmicas recolhidas testemunham uma modesta ocupação desde os meados do séc. I d.C., com um aumento da população e do seu nível económico no séc. n, até momento mal definido da Alta Idade Média.

Fez-se um esforço para reconhecer e distinguir as cerâmicas do Baixo Império das pós-romanas, mas infelizmente pouco se pode avançar a partir destes achados sem estratigrafía.

São de salientar as quantidades apreciáveis de "sigillata clara» especialmente do tipo A e a quase total ausência de «sigillata hispânica» dos centros produtores do Ebro. Isto sugere abastecimento por rotas marítimas, com exclusão quase total de comércio com o interior. A quantidade considerável de almofarizes e alguidares de cerâmica comum sugere a existência de qualquer pequena indústria ou comércio local.

Summary: The non-metallic finds from a small Roman villa, situated just

North of Cascais (Portugal) are here presented. As the site, on the crest of a hill, had suffered severe erosion and, moreover, had been ploughed for several centuries, it proved impossible to recuperate any stratigraphy during its excavation. Therefore, it was decided to present the material in the form of a simple catalogue in order to give the reader an overview of the different materials, their forms and types, and especially their relative 
quantities, available and used in such a provincial villa. The ceramics encountered attest to a tentative, small occupation from the middle of the first century A.D., with an increase in the population and its monetary means during the second century until an, as yet ill defined, moment in the early middle ages.

An effort was made to recognize and define the late- and postRoman coarseware, but unfortunately not much could be learned from these, unstratified, pottery finds. To be noted are: the large quantities of "terra sigillata chiara», especially type "A», and the wellnigh absence of "terra sigillata hispânica» from the production centres in the Ebro valley. Indications probably of strong maritime commercial ties to the almost exclusion of overland commerce. The relative amount of large coarseware bowls found may suggest that a small shop functioned here during some period of the villa's existance. 


\section{A VILLA ROMANA DO ALTO DO CIDREIRA (CASCAIS) \\ - OS MATERIAIS}

\section{INTRODUÇÃO}

Ao apresentar o espólio da villa do Alto do Cidreira, é a falta absoluta de estratigrafía que nos impede tirar quaisquer conclusões cronológicas. Podemos apenas sugerir os limites cronológicos da sua ocupação, que são todavia muito latos e mal definidos. À falta de datação segura para a cerâmica comum, restam-nos os escassos fragmentos de «paredes finas», «terra sigillata» e vidro para datar a primeira época de habitação no Alto do Cidreira. Esta escassez de material datável do séc. i faz-nos pensar que a villa foi um modesto estabelecimento naquela época e que a maior afluência de ocupantes só se registou no decorrer do séc. $\mathrm{n}$.

A relativa abundância de «terra sigillata clara» atesta, pelo contrário, em nosso entender, maior ocupação e um maior poder económico a partir dos meados do séc. $\mathrm{n}$ e até, pelo menos, ao séc. $\mathrm{v}$. A cerâmica pós-romana é prova duma persistência humana mais ou menos contínua durante muitos séculos. Não é possível, porém, determinar até quando é que o local foi habitado : a cerâmica comum medieval é, geralmente, a «enteada» de qualquer escavação arqueológica, de maneira que está mal publicada; o corpus de formas e fabricos com cronologias seguramente documentas é ainda muito rudimentar, pelo que se torna difícil encontrar paralelos para os nossos achados.

Adoptamos o termo «pós-romana» exactamente por estarem ainda tão mal definidos os vestígios materiais da época medieval. 
A existência de formas quase iguais, a que podemos atribuir quer uma cronologia romana, quer pós-romana, faz-nos pensar que a presença humana no Alto do Cidreira deve ter sido efectivamente contínua, talvez com número variável de ocupantes.

Um conjunto tão pobre em perfis completos não merece uma publicação com tipologia própria. Faremos uma apresentação em forma de «catálogo» dos vários fabricos e formas encontrados, para dar uma panorâmica de toda a gama de cerâmica fina e comum de que os habitantes do Alto do Cidreira se serviram, durante os muitos séculos da sua ocupação. E como, além disso, é quase impossível separar com segurança absoluta as pastas comuns da época tardo-romana das da Idade Média, enumerá-las-emos todas num catálogo que abrange tanto a ocupação romana como a pós-romana.

Apontaremos no catálogo outras peças com perfil semelhante para darmos uma ideia não só da quantidade em que cada tipo está representado, como também, no caso da cerâmica comum, das várias pastas e tamanhos em que foi fabricada. Pensamos ter incluído aqui todos os tipos e formas representados pelos vários milhares de cacos retirados da escavação do Alto do Cidreira, e só não podemos dar uma certeza absoluta por causa do estado extraordinariamente fragmentado da cerâmica.

Tentámos atribuir uma cronologia às formas de cerâmica comum e às suas variantes, mas, dadas as suas características regionais, não nos pareceu válido procurar muitos paralelos fora da Lusitânia. Por isso, citámos, sempre que possível, peças semelhantes encontradas no território actualmente português. Tivemos, todavia, que recorrer também à bibliografia mais conhecida sobre a cerâmica comum do Norte do Império para encontrar paralelos convenientes. Tal circunstância não implica, em nosso entender, uma ligação comercial com as províncias romanas do Norte; sublinha, isso sim, a falta de ligações intensas com outras zonas geográficas, designadamente no interior da Lusitânia. As relações comerciais reconhecem-se, aliás, na presença relativamente abundante de «terra sigillata clara».

Por serem pouco numerosos, começaremos por apresentar os objectos de osso, os vidros e as lucernas. Os pesos de tear e de pesca encontram-se no final do estudo sobre a cerâmica comum. 
Serão usadas as seguintes abreviaturas no texto :

c. - circa;

diâm. - diâmetro;

n. i. - não ilustrado;

TSG — «terra sigillata clara»;

TSH — «terra sigillata hispânica»;

TSS — «terra sigillata sud-gálica».

As abreviaturas bibliográficas encontram-se enumeradas na bibliografia, no final deste estudo.

Cada peça será identificada pelo seu número de inventário e pelo número do quadrado em que foi achada: p. ex., a panela $n .^{\circ} 7 \mathrm{com}$ o n. ${ }^{\circ}$ de inventário $18-\mathrm{HH}-5$ é a décima oitava peça inventariada do quadrado H H-5. A indicação «sup 81» ou «sup 82» refere-se a achados superficiais dos anos 1981 e 1982.

As cores atribuídas às cerâmicas são as das Muriseli Soil Color Charts (Maryland, 1975), embora antecedidas dos nomes tradicionalmente usados.

\section{TERRACOTA}

Uma pequena máscara, encontrada pela Sr. ${ }^{\text {a }}$ Maria Coelho na parte mais alta da estação do Alto do Cidreira, foi adquirida por Guilherme Cardoso e, em seguida, oferecida ao Museu-Biblioteca dos Condes de Castro Guimarães ( $\left.{ }^{(}\right)$.

Máscara de um negro. Achado de superfície, sem n. ${ }^{\circ}$ de inventário. Alt. total $22 \mathrm{~mm}$, largura máxima preservada $24 \mathrm{~mm}$, grossura da parede entre $11 \mathrm{~mm}$ no queixo e $4,5 \mathrm{~mm}$ na testa. Pasta micácea, medianamente fina com muitos pontinhos de óxido de ferro, alguns grãos, relativamente largos, de quartzo e feldspato, de cor ocre amarelada (Munsell 8,75 YR $7 / 6$.

A máscara foi moldada em meio molde: do lado de dentro mantêm-se visíveis as dedadas do oleiro. O fabrico é muito cuidado e pormenorizado, por exemplo os contornos dos olhos são bem *

P) Cf. Branco, Mini-máscara. 
marcados, enquanto as pupilas e as narinas foram nitidamente cavadas no barro ainda maleável.

Três orifícios, dois na testa e outro no lado esquerdo da boca, podiam ter servido para pendurar ou fixar a peça. No interior deles, são visíveis os riscos da broca com que a máscara foi furada depois da sua cozedura. Não podemos afirmar se estes buraquinhos são antigos ou se foram feitos durante os anos em que a peça esteve na posse de Maria Coelho. A parte da cara está marcada com muitos riscos finos - resultado duma escova dura numa tentativa da $\mathrm{Sr}^{\mathrm{a}}$ Coelho para limpar a peça depois de a ter encontrado ?

É difícil dizer para que servia esta peça, até porque não temos qualquer indicação sobre se se trata da metade duma cabecinha inteira ou se se trata apenas da parte frontal que servia de decoração aplicada sobre qualquer outra peça. O tema da máscara de negro é muito frequente na Antiguidade, e tem antecedentes na arte grega, onde se encontram máscaras de vários tipos, especialmente ligadas com a comédia no teatro $\left({ }^{2}\right)$. No British Museum não existe nada de semelhante na sua grande colecção de terracotas $\left({ }^{3}\right)$, e não conseguimos identificar paralelos na bibliografia ao nosso alcance. Uma cronologia da segunda metade do séc. i ou do séc. n não estará longe da verdade, mas apenas podemos citar o tema da máscara de negro noutros materiais. Lucernas do tipo «Firmalampe» (Dressel/ /Lamboglia 5 C) são muitas vezes decoradas com máscaras de negro no disco. Datam dos fins do séc. i e do século seguinte. Lucernas de bronze em forma de cabeça de negro também se encontram desta época $\left({ }^{4}\right)$, e dois vasos de vidro em forma de cabeça de negro foram achados em Pompeios $\left({ }^{5}\right)$.

(2) Budischovsкy, Le thème du nègre, p. 195.

(3) Agradecemos a gentileza do Doutor D. M. Bailey por prontamente nos ter fornecido esta informação.

(4) Budischovsky, Le thème du nègre, Est. XII, p. 197.

(5) I sings, Dated Finds, forma 78 A, p. 93. 


\section{OBJECTOS DE OSSO}

1 8-sup-82 Dado, $6 \mathrm{~mm}$ de lado. Est. I.

Dados em osso eneontram-se em muitas estações romanas e em camadas de todas as épocas. Os exemplares mais perfeitos têm, como o nosso, os pontos distribuídos de maneira que a soma dos lados opostos dá sempre sete. Dois exemplares de Verulamium datam dos inícios do séc. $m$ e meados do séc. IV. Cf. Frere, V erulamiun, III, n. ${ }^{\text {ss }} 284,285$, p. $73-74$, fig. 32.

2 9-HG-23 Lígula. Comprimento máx. conservado 189 mm. Est. I.

A lígula conserva apenas a base da própria espátula. O outro lado deste instrumento cosmético ou médico termina numa ponta bastante afiada. A espátula podia servir tanto como conta-gotas como para misturar cosméticos, pomadas, unguentos ou até tintas de pintar $\left(^{6}\right)$. É impossível atribuir uma datação a estes instrumentos de uso diário. Cf. Fouilles de Conimbriga, VII, n. ${ }^{\text {os }} 265-$ -268, p. 146-147 e 149, Est. XXXVI: lígulas encontradas em depósitos flavianos, trajânicos e tardios.

3 9-IH-12 Tabuinha de tecelagem. Fragmento. Altura preservada $35 \mathrm{~mm}$, largura máxima preservada $16 \mathrm{~mm}$, espessura máxima preservada 7,5 $\mathrm{mm}$. Est I.

Uma peça comparável, ainda inédita, provém de Torre da Palma $\left({ }^{7}\right)$ sem qualquer indicação do seu contexto arqueológico. Esta tem a forma de leque do nosso exemplar, repetida na parte inferior, e três orifícios de cada lado. Na nossa peça, conservam-se indicações de três destas aberturas que serviam para passar os fios na tecelagem de cordão. Geralmente, estas tabuinhas consistem em pequena-s placas de forma triangular ou quadrada, de bronze ou osso $\left({ }^{8}\right)$. Contudo, também existiam exemplares decorados, tal como havia «separadores», agulhas e cossoiros com decoração gravada.

(6) Bliquez, Greek and Roman Medicine, p. 13.

(7) Museu Nac. de Arqueologia e Etnologia, invent. n. ${ }^{\circ}$ 10.001.1138.79.

$\left(^{8}\right)$ Ponte, Fiação, p. 133-147, p, 137-138. 
Outro fragmento parecido, inédito, da sepultura 22 de Tróia $\left({ }^{9}\right)$ tem a parte superior quase igual ao nosso e a parte inferior muito estragada. Esta peça foi encontrada em conjunto com um fundo de vidro que apresenta uma «coroa» de pequenos pés repuxados, pertencente a um copo de forma rara datável do séc. $\mathrm{n}$ até inícios do séc. ui $\left({ }^{10} 11\right)$. Também um prato de TSC «C», e outro de TSC «D» estão marcados como provenientes da mesma sepultura. O autor Hayes data a forma de «C» dos anos c. 260-320, e o prato de «D» da primeira metade do séc. v ou mais tarde (n). É óbvio (e de lamentar) que não podemos confiar no inventário desta sepultura. Mesmo que a sepultura tenha sido fechada já no séc. $\mathrm{m}$, o fragmento da tabuinha podia ter tido uma sobrevivência relativamente longa.

É mais que provável que os três exemplares por nós conhecidos tenham sido esculpidos pelo mesmo artesão.

4 45-1 H-16 Separador de tear. Comprimento preservado $167 \mathrm{~mm}$. Est. I.

As dimensões e a decoração deste separador são muito semelhantes às dos muitos encontrados em Conimbriga e publicados com uma explicação sucinta da sua utilidade. Cf. Fouilles de Conimbriga, VII, n. ${ }^{\text {ss }} 181-190$, p. 53-54, Est. XII.

5 109-HH-25 Agulha. Fragmento do corpo e buraco. Comprimento preservado $34 \mathrm{~mm}$. Est. I.

G Sup 77 Agulha. Fragmento do corpo e buraco. Comprimento preservado $57 \mathrm{~mm}$. Est. I.

Estas agulhas, com decoração de círculos concêntricos, são comparáveis aos n.os 73,75 e 76 das escavações antigas de Conimbriga, e a outra encontrada numa camada de destruição da chamada «ínsula do vaso fálico» nas escavações luso-francesas, todas, infelizmente, sem cronologia associada $\left({ }^{12}\right)$. Cf. Ponte, Fiação, n. ${ }^{\text {s }} 73,75$ e 76, p. 138, 139, 144, Est. IV; Fouilles de Conimbriga, VII, n. ${ }^{\circ} 310$, p. $80-81$, Est. XII.

(9) Museu Nacional de Arqueologia e Etnologia, invent. n. ${ }^{\circ}$ 983.579.35.

(10) Fouilles de Conimbriga, VI, p. 189, 191, Est. XLI.

(11) Hayes, Late Roman Pottery, forma 48-B, p. 67; forma 67, p. 116.

(12) Existem mais dois fragmentos de agulhas assim decoradas e cinco de agulhas lisas ou alfinetes com comprimento preservado entre os 10 e $42 \mathrm{~mm}$. 


\section{VIDRO}

O espolio de vidro exumado do Alto do Cidreira é muitíssimo pobre. O terreno, tão remexido e lavrado, se nos deixou a cerâmica em fragmentos pequenos, quase pulverizou o vidro. De entre essas autênticas «migalhas» destacam-se as seguintes peças :

1 16-II-1 Pyxis (?), fragmento do bordo e da parede. Soprado em molde. Vidro transparente de boa qualidade, com poucas bolhas de ar pequenas, cor de âmbar, filandrado e com leve irisão. Diâm. do bordo c. $50 \mathrm{~mm}$. Est. II.

A classificação deste fragmento como forma de uma pyxis é problemática. O bordo, de secção quadrada, concorda com o tipo; todavia, é de diâm. reduzido. A forma, Isings 22, geralmente tem diâm. de c. $100 \mathrm{~mm}$, ou mais, e os exemplares publicados de modo geral foram fabricados de vidro azul ou verde esmeralda. Datam de meados do séc. i (13). Van Lith apresenta vários exemplares datáveis a partir do reinado de Augusto até à época flávia $\left({ }^{14}\right)$. A qualidade do vidro e a cor do nosso fragmento sempre indicam uma datação do séc. i. Cf. Fremersdorf, Blaugrüne Glas, n. os N 866 e N 867, com diâm. de c. 70 mm, p. 37, Est. 69, datados do séc. ï; BERGER, Vindonissa, n. ${ }^{\circ} 35$, p. 27, Est. 3-35, 17-6, corn diâm. de $82 \mathrm{~mm}$, da época de Tibério.

2 85-GH-1 Garrafa ou frasco, fragmento da asa com nervuras longitudinais. Vidro verde gelo, com bolhas de ar, picado e com leve irisão. N. i.

Esta asa pertencia, mais provavelmente, a uma garrafa de forma Isings 50 ou 51. As garrafas existem com asas de duas nervuras a partir do reinado de Cláudio; o uso de asas com multinervuras, como neste caso, torna-se comum em meados do séc. II ${ }^{(15)}$. A forma perdura até inícios do séc. $m\left({ }^{16}\right)$.

(13) Isings, Dated Finds, forma 22, p. 38.

(14) VAn Lith, Asciburgium, p. 240.

(15) Isings, Dated Finds, formas 50 e 51, p. 63-69.

(16) VAn Lith, Valkenburg, p. 77. 
3 21-FG-24 Taça, fragmento do bordo e da parede. Vidro incolor de boa qualidade, picado e com irisão, leitoso e esfoliado. Bordo polido ao fogo. Diâm. c. 90 mm. Forma Isings $85\left({ }^{17}\right)$. Est. II.

A qualidade do vidro e a forma apontam para uma datação dos fins do séc. i até, quando muito, os inícios do séc. m. A forma Isings 85 encontra-se numa sepultura de c. 90 d. C., em Paredes e ainda nos meados do séc. $m$ em Verulamium. Cf. Pereira, Paredes, n. ${ }^{\text {os }} 16$ e 17, p. 61, Est. Ill ; Charlesworth, Verulamium, 3, n. ${ }^{\circ} 116$, p. 156-157, fig. 64-66; ALARCÃo, F arrobo, n. ${ }^{\circ} 3$, sepultura 13, p. 9,17, Est. II.

4 22-FG-24 Pé de argola, fragmento. Qualidade de vidro idêntica ao anterior. Diâm. c. 44 mm. N. i.

Será possível que este fragmento, encontrado no mesmo quadrado, aliás num nível mais alto de c. $40 \mathrm{~cm}$, faça parte da taça n. ${ }^{\circ} 3$ ?

5 87-GH-1 Taça, fragmento do bordo e da parede. Forma e qualidade de vidro como o n. ${ }^{\circ}$ 3. Picado e com irisão. Diâm. c. $80 \mathrm{~mm}$. N. i.

6 44-IH-16 Copo ou boião. Fragmento da base. Vidro incolor de boa qualidade, irisado e esfoliado. Est. II.

É difícil de adivinhar a forma completa deste fragmento. Podia ser um copo alto, talvez até decorado com depressões; outra possibilidade é pertencer a um boião. Seja como for, a qualidade do vidro aponta para uma cronologia a partir dos fins do séc. i até meados do séc. m. Cf. WelKer, Nida-Heddernheim, I, n. ${ }^{\circ} 285$, p. 123. Est. 17. Veja também HARDEN, Recensão sobre Nida-Hedernheim, p. 189-190; HAYes, Ontario-Glass, $n .^{\circ} 187$, p, 65, fig. 6 datada «possivelmente» do séc. II ; AlARCÃo, Vidros de Conimbriga, n. ${ }^{\circ} 135$, p. 89 , Est. V.

7 8-IH-12 Copo cónico. Fragmento da pança. Vidro verde musgo, de boa qualidade, com algumas bolhas de ar pequenas, irisado, picado e com leve corrosão. Soprado em molde com decoração em forma de favo de mel. Forma Isings 107 A. Est. II.

(17) IsINGs, Dated Finds, forma 85, p. 101-103. 
Infelizmente não conseguimos encontrar paralelo da Lusitânia para este copo de forma vulgar mas de decoração pouco divulgada. Isings apenas cita um exemplar bem datado dos meados do séc. Iv (18). De Marselha podemos indicar dois fragmentos de vidro verde com decoração moldada, que, aliás, apresenta temas cristãos. São fragmentos de cronologia tardia: fins do séc. v e séc. vi ( $\left.{ }^{19}\right)$. A qualidade e cor do vidro do $\mathrm{n}^{\circ} 7$ concordam com uma cronologia a partir do séc. Iv ; existe, portanto, a possibilidade de este ser um vidro de período francamente tardo-romano.

Encontramos duas qualidades de vidro de janela na estação do Alto do Cidreira.

A primeira está representada pelo fragmento $88-\mathrm{GH}-1$, de vidro verde-relva-amarelado (espessura no centro; $4 \mathrm{~mm}$. N. i.). Este fragmento tem superfície lisa dum lado e é áspero do outro, prova de que foi fundido sobre um molde ainda em estado líquido. Eram estas a técnica e a cor do vidro de janela nos sécs. i e n (20)

Os outros fragmentos (89-GH-1, 90-GH-1 e 12-HH-3, N. i.), de vidro incolor e espessura entre 2 e $2,5 \mathrm{~mm}$, devem datar dos sécs. ni ou IV. Parece tratar-se de vidro soprado, que foi posteriormente aplanado num forno relativamente brando, ficando liso nas duas superfícies $\left({ }^{21}\right)$.

Três fragmentos (88-GH-1, 89-GH-1 e 12-HH-3) conservam o bordo arredondado e ligeiramente levantado que é característico do vidro de janela romano de todas as épocas.

\section{PAREDES FINAS}

A ausência quase completa de «paredes finas» no Alto do Cidreira constitui a base da nossa hipótese acerca da escassa presença humana no local durante o séc. i. São os seguintes os dois

(18) ID., ibid., forma 107 A, p. 133.

(19) Foy, Marseille (1980), N. os 70 e 79, do período 2-A, fases 3 e 4, p. 290-296, fig. 3.

(20) Charlesworth, Hemel Hempstead, p. 203.

(21) ID., ibid, p. 203-204.

Conimbriga, 27 (1988), 61-140 
fragmentos identificados, mais um com aspecto de ser imitação de «paredes finas» em cerâmica comum.

1 1-Sup-77 Taça da forma Mayet LUI, fragmento do bordo e da parede. Diâm. 45 mm. Est II.

A pasta branca (10 YR 8/2,5) é do fabrico mais grosseiro de Mérida, ou seja, do grupo 2-a que estabelecemos para a necrópole de Santo André (22). O engobe é baço e fino, de cor laranja (2,5 YR 7/8) e não foi aplicado no fundo interior da peça, o que, conforme Mayet notou, era corrente para estas taças situadas cronologicamente na segunda metade do séc. i (23). Cf. MaYet, Parois Fines, n. ${ }^{\circ} 621$, p. 114, 115, Est. LXXIV.

2 1-GH-1 Tigela (?), fragmento minúsculo de bojo. Pasta igual à peça anterior. Engobe alaranjado (2,5 YR 6/8) com brilho metálico e quase cinzento do lado interior. N. i.

3 10-HH-15 Copo ou púcaro de bordo em forma de aba descaída. Fragmento do bordo. Diâm. 118 mm. Est. II.

A pasta ocre $(7,5$ YR 8/4) é muito fina, com abundância de palhetas pequenas de mica, pontinhos castanhos de hematite e escassos grãos angulosos de quartzo. Uma aguada também muito fina e de cor ocre (7,5 YR 8/5) talvez se deva apenas ao alisamento com água da parede. O dorso do bordo foi brunido com uma pedrinha ou instrumento similar. Embora a pasta se pareça com as pastas depuradas de "paredes finas» do melhor fabrico, não conhecemos fabrico a que esta peça possa ter pertencido. A forma do bordo em aba curta faz lembrar os púcaros ou copos asados mais requintados da época flávia ou de inícios do séc. n. Cf. Nolen, Alto Alentejo, n. ${ }^{* *} 180-183$, p. 72-73, 191, Est. XXV.

(22) Nolen, Santo André, p. 60.

(23) MaYet, Parois Fines, forma LUI, p. 114.

Conimbriga, 27 (1988), 61-140 


\section{TERRA SIGILLATA SUDGÁLICA}

Os quinze fragmentos de TSS encontrados na escavação do Alto do Cidreira representam apenas sete formas diferentes. Constitui um conjunto pobre, em comparação com a TSC ou a TSH, o que reflecte não apenas a pobreza mas também, e sobretudo, a escassa ocupação da estação durante o séc. i, visto que a TSS deixou de ser importada para o território português depois dos anos $70 / 80\left({ }^{24}\right)$. A ausência total de peças decoradas é mais uma indicação da relativa modéstia dos habitantes da villa no séc. i.

Dado que não se conserva uma única marca, foi-nos impossível atribuir os diversos fragmentos aos muitos oleiros da Gália. Embora as pastas não sejam bons indicadores de proveniência, podemos designar a área de fabrico sem grande hesitação. Ensaiámos uma tal separação de proveniências numa tentativa de estabelecer as vias mais importantes de comércio durante o séc. i da nossa era. Assim, pensamos poder reconhecer o fabrico da região de La Graufesenque em todos os fragmentos, com exclusão completa da importação de Montans (25). Mais uma vez nos encontramos perante o que é normal para as estações da Lusitânia: foi sobretudo Graufesenque que conseguiu dominar o nosso mercado.

A única forma representada por mais do que uma só peça é Dragendorff 15/17.

\section{Pratos da forma Dragendorff 15/17}

1 2-HG-19 Fragmento da base. Diâm. do pé $80 \mathrm{~mm}$. Est. II.

2 3-GH-19 Fragmento da parede e do bordo. Diâm. do bordo $142 \mathrm{~mm}$. Est. II.

Trata-se de dois pratos diferentes, ambos de pasta laranja-rosada, engobe homogéneo, pouco brilhante, cor de tijolo e ligeiramente manchado no caso do $\mathrm{n}^{\circ}{ }^{2}$. Os perfis e a qualidade do

(24) A propos des céramiques de Conimbriga, p. 41.

${ }^{(25)}$ Agradecemos à Dr. ${ }^{a}$ Conceição Lopes a assistência prestada na escolha e determinação da terra sigillata sudgàlica. 
engobe acetinado destes pratos permitem datá-los da época cláudia ou, o mais tardar, do tempo de Vespasiano. Cf. Fouilles de Conimbriga, IV, n. ${ }^{\circ} 193$, p. 94, 104, Est. XXVII, com marca de LENTINVS do período pré-flávio.

3 22-HG-10 Fragmento do bordo e da parede. Pasta laranja-rosada, fina e dura, com calcite em partículas finas. Engobe grosso e baço, cor de tijolo, estalado na parede exterior. Diâm. 156 mm. Est. II.

O perfil aberto indica uma data mais avançada relativamente aos dois pratos anteriores: talvez os inícios da época flávia. Cf. Fouilles de Conimbriga, IV, n. ${ }^{\text {os }}$ 199-201, p. 93, 104-105, Est. XXVII, de camadas remexidas.

\section{Outras formas encontradas}

4 23-HH-10 Prato da forma Dragendorff 18, fragmento do bordo e da parede. Pasta vermelha clara, pouco esponjosa, com calcite em partículas finas. Engobe espesso e medianamente brilhante, vermelho. Diâm. $160 \mathrm{~mm}$. Est. II.

O perfil aberto torna-se comparável aos pratos de Conimbriga datados do reinado de Vespasiano. Cf. Fouilles de Conimbriga, IV, n.os 232, 224, p, 93, 107, Est. XXIX.

5 1-HG-22 Taça da forma Dragendorff 24/25, fragmento do bordo e da parede. Pasta fina e dura com pequenos pontinhos de calcite, laranja rosada. Engobe cor de tijolo, pouco espesso, brilhante e aderente. Diâm. c. 90-100 mm. Est. II.

A ausência de decoração de «guiloché» no bordo é rara nesta forma; a ranhura tanto no exterior como no dorso do bordo é, todavia, frequente na produção gálica. Cf. Fouilles de Conimbriga, IV, n. ${ }^{\circ}$ 168, p. 92, 101, Est. XXV; Nolen, Santo André, E 5,13, p. 48, 133-134, encontrado num enterramento dos fins do séc. i ou inícios do séc. n. ${ }^{6}$

6 15-II-1 Prato da forma Dragendorff 36, fragmento do bordo. Hestos de decoração de folhas de água de barbotina. Pasta compacta e limpa, com apenas pontinhos raros de calcite, laranja acastanhada. Engobe espesso e aderente, medianamente brilhante, cor de tijolo. N. i. 
Esta forma, rara em Conimbriga com apenas seis exemplares registados foi, naquela estação, datada da época flávia. Fazia parte do conjunto "A» do esquema de serviços flávios estabelecido por Vernhet ( ${ }^{26}$ ). Cf. Fouilles de Conimbriga, IV, n. ${ }^{\text {os }} 175,176$, p. 92, 102, Est. XXV.

7 4- e 5-GH-19 Taça da forma Dragendorff 33, dois fragmentos do bordo e bojo que não se colam. Pasta dura um pouco esponjosa, todavia limpa, rosada. Engobe espesso e medianamente brilhante, vermelho alaranjado. N. i.

A pequenez dos fragmentos não nos deixa determinar se a taça tinha ou não um pequeno ressalto entre a pança e a base. Parece que um ressalto é indicativo duma cronologia pré-flávia (27). A forma, porém, não se torna abundante antes do período de Domiciano-Nerva e ainda continua a ser produzida durante o séc. m ${ }^{(28)}$. $\mathrm{O}$ engobe e a pasta do nosso exemplar apontam para uma cronologia flávia.

Ainda podemos assinalar os seguintes n.os, de forma irreconhecível

8 5-FG-24 Fragmento de pé e base duma tigela ou taça. N. i.

9 I-IH-21 Fragmento de pé dum prato. N. i.

\section{TERRA SIGILLATA HISPÂNICA}

Os fragmentos de TSH do Alto do Cidreira podem dividir-se em três grupos: a sigillata do ambiente comercial de Andújar, a do vale do Ebro e, finalmente, a TSH tardia.

O primeiro (dezassete fragmentos) forma um conjunto homogéneo, de pasta relativamente grosseira com abundância de calcite, cuja cor vai desde o amarelo alaranjado (Munsell 6,25 YR 7/6) ao

(26) Vernhet, em Bémont, La terre sigillée gallo-romaine, p. 100.

(27) Fouilles de Conimbriga, IV, p. 92.

(28) Oswald, Margidunum, p. 5 e 8. 
laranja acastanhado (Munsell 2,5 YR 5/6). 0 engobe, geralmente vermelho (Munsell 10 YR 5/6) ou cor de tijolo (Munsell 1,25 YR 4/8), é espesso, baço ou mostrando um leve brilho ${ }^{29}$ ). Tudo isso é característico da produção da área de Andújar e, por isso, deve situar-se cronologicamente entre os anos 30/40 e a segunda metade do séc. II $\left.{ }^{(30}\right)$. Entre os achados reconhecíveis deste fabrico, figura o prato da forma Dragendorff 15/17, tal como aconteceu com a TSS, embora a forma mais numerosa seja a taça da forma Dragendorff 27. Estão representadas cinco peças, mas apenas duas delas merecem ser ilustradas.

\section{Tigela da forma Dragendorff 27}

1 9-HI-7 Fragmento do bordo e da carena. Diâm. c. 90 mm. Est. II.

2 13-HH-15 Fragmento da carena. N. i.

a 1-GH-25 Fragmento do bordo. Diâm. do bordo c. 120 mm. N. i.

Trata-se de três tigelas grandes de bordo aberto e carena mal definida. Estas são características indicativas de uma cronologia da segunda metade do séc. II. Cf. MAYet, Sigillées Hispaniques, Vol. I, p. $45-56$, vol. II, n. ${ }^{\text {s }} 32,35,36$, Est. XXIV.

4 1O-FG-34 Tigela mais provavelmente da forma Dragendorff 27, fragmento da base. Pé bem definido, de perfil triangular. Diâm. do pé $48 \mathrm{~mm}$. Est. II.

Esta tigela, como as precedentes, será de tamanho grande e de cronologia avançada. Um grafito no fundo exterior $A$ (nii?), marca do utente, é comparável a vários encontrados na cerâmica comum do museu de Vila Viçosa ( ${ }^{31}$ ) e outro de Conimbriga ( ${ }^{32}$ ). Cf. MAYet, Sigillées Hispaniques, n. ${ }^{\circ}$ 34, 36, Est. XXIV.

(29) A cor e a qualidade das pastas e dos engobes apenas serão indicadas quando divergirem desta norma.

${ }^{30}$ ) T. S. H. Terra Sigillata Hispanica, Monografias del Museo Arqueológico Nacional, Tomo I, n. ${ }^{\circ}$ 2, Madrid 1983, p. 163-164.

(31) Nolen, Alto Alentejo, n. ${ }^{\circ}$ 51, p. 178,. Est. LVII (de escala 1:3).

(32) Fouilles de Conimbriga, II, p. 127, n. ${ }^{\circ} 150$. 
5 3-FG-34 Fragmento da base. Pé baixo de secção triangular, porém mal definido. Diâm. do pé $35 \mathrm{~mm}$. Est. II.

Ainda que o diâm. do pé corresponda a uma tigela mais pequena que as anteriores, o pé baixo e mal definido é, mais uma vez, indicativo duma cronologia já do séc. $n$.

\section{Outras formas encontradas}

6 6-Sup-81 Fragmento da base. Pé muito baixo. Diâm. $70 \mathrm{~mm}$. Est. II.

A parede grossa e a moldura mal definida são indicativos de uma cronologia avançada, ou seja, fins do séc. i até meados do séc. II $\left.{ }^{\mathbf{3} 3}\right)$. Cf. MAyet, Sigillées Hispaniques, vol. I, p. 45, vol. II, n. ${ }^{\circ} 10$, Est. XXII.

O segundo grupo de TSH consta apenas de quatro fragmentos, de pasta vermelha clara (Munsell $10 \mathrm{R}$ 6/6-7/6), fina e compacta, com muitos pontinhos pequenos de calcite. $\mathrm{O}$ engobe, de cor de tijolo (Munsell $10 \mathrm{R} \mathrm{5/8)}$ ou vermelho alaranjado (Munsell 1,75 YR 5/6), é delgado e tem um certo brilho. Este tipo de fabrico sugere uma origem no vale do Ebro, no ambiente comercial de Trício. A quantidade de fragmentos, muito inferiores aos de Andújar, é de notar. Estas quantidades relativas são nitidamente opostas ao que se tem verificado noutras estações portuguesas que conheceremos, como, por exemplo, Conimbriga ou Santo André. Será que a exportação de Andújar se efectuou por via marítima para melhor abastecer as villae e cidades costeiras?

7 4-FG-24 Fragmento com decoração estampada, provavelmente da forma Dragendorff 37. Motivo: uma flor, tipo malmequer, dentro dum círculo. Est. II.

Neste fabrico, a forma Dragendorff 37 é geralmente datada desde os fins do séc. i até aos meados do séc. n, não estando ainda

(33) Encontrámos mais três fragmentos de taças desta forma. 
documentada a sua suposta continuação para além deste período $\left({ }^{34}\right)$. Cf. Fouilles de Conimbriga, IV, n. ${ }^{\circ}$ 131, p. 159-160, Est. XLI, dos fins do séc. i até aos meados do séc. ii ; MAYET, Sigillées Hispaniques, vol. II, n o 638, Est. CXLVII, vol. I, p. 90.

8 7-HG-23 Taça da forma Dragendorff 33, fragmento do bordo. N. i.

9 2-HH-22 Taça de forma indeterminável, fragmento da base. N. i.

O último grupo reconhecido na TSH do Alto do Cidreira consta de dois fragmentos de fabrico tardio. A sua proveniência é ainda desconhecida, talvez seja também o vale do Ebro $\left({ }^{35}\right)$.

10 3-IH-21 Taça da forma Dragendorff 37, fragmento do bojo. Pasta compacta e limpa, com poucos grãos pequenos de quartzo e mica, de cor laranja-claro (Munsell 2,5 YR 7/8). Engobe muito gasto (não temos qualquer indicação se também existia no interior). Decoração de grinaldas de chaveirões. Est. II.

Este motivo de decoração é frequente, embora não seja o mais usado na forma 37 tardia. Cf. MezQuiriz, Terra Sigillata Hispánica, Est. 197-42, uma taça de Navarra com engobe somente na parede exterior (voi. I, p. 290); Est. 199-47, outra taça de Navarra sem engobe na base interior (voi. I, p. 290); Est. 281-2, cuja cronologia indicada pela qualidade do engobe e pelo motivo da decoração, cabe no séc. IV (voi. I, p. 411); ID., Pompado, II, motivo J 3, fig. 30 de Arcedianato, 1965, Sector C.F., Estrado II, dos séc. iv e iv (p. 19); MAYET, Sigillées Hispaniques, a decoração assemelha-se ao segundo estilo decorativo (p. 259), a pasta e engobe concordam com o tipo B (p. 250).

11 15-HH-10 Fragmento da pança de forma desconhecida. N. i.

A qualidade e cor da pasta e o engobe deste fragmento integram-se no grupo «A» da classificação da TSH tardia de Mayet, cf. Sigillées Hispaniques, vol. I, p. 250.

(34) Mayet, Sigillées Hispaniques, vol. I, p. 84-85.

(35) ID., ibid., vol. I, p. 283. 


\section{TERRA SIGILLATA CLARA}

Em flagrante contraste com o que acontece com a TS sudgálica ou hispânica, o Alto do Cidreira apresenta uma colecção de TSC rica e diversificada em fabricos e pastas. Isso não só fala a favor da ocupação mais intensa durante o séc. $\mathrm{n}$ e seguintes, mas também das vias marítimas e do comércio que ligavam a costa ocidental de Lusitânia ao Norte de África, zona de origem da TSC «A», «C»e $« \mathrm{D} »$.

\section{«Terra Sigillata Clara A»}

De TSC «A» encontramos um total de 61 fragmentos, representando, pelo menos, cinco formas diferentes. A pasta é, regra geral, bem classificada, com muitos grãos pequenos e angulosos de quartzo. A sua cor varia entre o laranja-avermelhado (Munsell 1,25 YR 7/8) e o vermelho-claro (Munsell 10 R 6/8). O engobe, espesso e na maioria das peças bem preservado, mostra uma superfície com borbulhas pequeníssimas (o dito aspecto de «casca de laranja»), quanto a cor é mais avermelhada do que a da pasta, variando do laranja/cor de tijolo (Munsel 1,25 YR 5/8) ao vermelho-claro (Munsell 10 R 6,5/8) ( ${ }^{36}$ ).

As formas documentadas por fragmentos classificáveis são as seguintes:

\section{Tigela da forma Hayes 3}

1 2-IG-22 Fragmento do bordo. Engobe muito gasto. O fragmento pequeno não conserva qualquer indicação da decoração de barbotina frequente nestas tigelas. Diâm. $112 \mathrm{~mm}$. N. i.

Cf. Hayes, Late Roman Pottery, n. ${ }^{\circ}$ 109, p. 23-25, fig. 2, da primeira metade do séc. $\mathrm{n}$.

(36) Somente será indicada a cor da pasta e/ou do engobe quando divergir da norma dos respectivos fabricos. 


\section{Tigela da forma Hayes $6 \mathrm{~B}$ ?}

2 1-FG-24 Fragmento da base com pé de argola. Diâm. do pé c. $60 \mathrm{~mm}$. Est. III.

Cf. Hayes, Late Roman Pottery, n. ${ }^{\text {os }} 16$, 17, p. 29-31, fig. 3, da segunda metade do séc. II.

\section{Taças da forma Hayes 9}

3 2-FG-24 Forma 9 A, fragmento pequeno da pança com decoração de «guilhoché». N. i.

4 13-FG-24 Forma 9 A, fragmento pequeno da pança com decoração de «guilhoché». N. i.

5 12-FG-24 Forma 9 B, fragmento do bordo com decoração de dois sulcos. Pasta laranja (2,5 YR 6/8), engobe laranja-claro (2,5 YR 7/8). Diâm. c. $160 \mathrm{~mm}$. Est. III.

Cf. Hayes, Late Roman Pottery, forma 9 A, p. 35-37, fig. 4, com cronologia de c. 100-160 e posterior; forma 9 B, p. 35-37, fig. 4, da segunda metade do séc. II.

\section{Taças da forma Hayes 14 A}

6 3-Sup-81 Dois fragmentos da parede e da base. Pasta cinzento acastanhada (2,5 YR 4/1), engobe espesso com brilho leve, laranja (2,5 YR $5,6 / 8)$, manchada de cinzento escuro. Est. III.

7 2-zona polícia Três fragmentos da parede e da base. Pasta laranja Munsel 2,5 YR 6/8, engobe quase completamente gasto. Diâm. c. $240 \mathrm{~mm}$. Est. III.

8 3-zona polícia Dois fragmentos da parede e da base. Pasta laranja Munsel 2,5 YR 6/8, engobe completamente desaparecido. N. i.

9 4-zona polícia Fragmento do bojo. Pasta laranja (Munsel 2,5 YR 6/8), engobe completamente desaparecido no exterior, fino e baço no interior.

N. i. ${ }^{(37)}$.

Cf. Hayes, Late Roman Pottery, forma 14 A, p. 39, 41, fig. 6, com cronologia de meados do séc. II.

$\left({ }^{37}\right)$ Existem mais sete fragmentos de bordos e dois de bases da forma Hayes 14 A. 


\section{Pratéis da forma Hayes 16}

10 31-HH-10 Fragmento da parede e da base. Pasta laranja (2,5 YR 6/8), cngobe fino e baço, muito estragado, ligeiramente mais escuro do que a pasta. Diâm. c. 140 mm. N. i.

11 2-HH-25 Fragmento da parede e da carena. Diâm. 148 mm. Est. Ili*

12 4-HH-25 Dois fragmentos da parede e da carena. Diâm. 142 mm. Est. III.

Cf. Hayes, Late Roman Pottery, forma 16, p. 41-42, fig. 6, com cronologia sugerida da segunda metade do séc. II e posterior.

\section{Pratos da forma Hayes 27}

13 6-HH-3 Fragmento do bordo. Pasta laranja (2,5 YR 5/8), engobe laranja-claro (2,5 YR 7/8). Est. III.

14 8-HH-25 Fragmento do bordo. Pasta laranja (2,5 YR 6/8), engobe laranja-claro $(2,5$ YR $7 / 8)$. N. i. $\left({ }^{38}\right)$.

Cf. Hayes, Late Roman Potery, forma 27, p. 49-51, fig. 8, cronologia sugerida: c. 160-220.

O final do fabrico de TSC «A» e a sua transição para o de «D» està documentado no Alto do Cidreira por:

15 1-HH-8 Prato da forma Hayes 32/58 (?). Fragmento da base. Pasta corno a da TSC «A», vermelha clara (10 R 6/7), engobe tipico para o fabrico «A» e aplicado dos dois lados, espesso e com aspecto de «casca de laranja», de cor vermelho-clara (10 R 6/8). Est. III.

É de notar que a forma desta base se assemelha à que se passou a usar nos primeiros pratos do fabrico de TSC «D». Cf. HAYES, Late Roman Pottery, forma 32/58, p. 95-96, fig. 14, cronologia de fins do séc. m-inícios do séc. $\mathrm{v}$.

(38) Existem mais dois fragmentos de pratos desta forma. 
«Terra Sigillata Clara C»

A «C» também foi muito procurada e usada pelas gentes que habitaram o Alto do Cidreira. Exumámos aí 46 fragmentos desse tipo de cerâmica (infelizmente são poucos os fragmentos de bordos), cuja gama de formas deve ter sido, porém, bastante limitada, uma vez que apenas nos foi possível reconhecer pratos das formas Hayes 50 e 58. A pasta da maior parte dos fragmentos está conforme às normas já conhecidas, ou seja: uma pasta limpa, compacta, com apenas escassos grãos muito pequenos de quartzo. A cor situa-se dentro dos vários tons de laranja (Munsell 2,5 YR 6/8$7 / 8$ ) ou vermelho-claro (Munsell $10 \mathrm{R} \mathrm{6/9-7/8).} \mathrm{O} \mathrm{engobe,} \mathrm{fino,}$ geralmente com pouco brilho, é aderente; mas, devido a ser uma película delgada, encontra-se muitas vezes gasto ou até mesmo desapareceu. A sua cor acompanha a da pasta.

\section{Pratos da forma Hayes 50}

16 1-HH-3 Forma 50 A, fragmento da parede. Lábio biselado. Engobe muito gasto, pouco brilhante, vermelho-claro. Diâm. c. 300 mm. Est. III.

17 2-HH-8 Forma $50 \mathrm{~B}$, fragmento da parede. Lábio arredondado. N. i. $\left({ }^{39}\right)$.

Cf. Hayes, Late Roman Pottery, forma 50 A, p. 69-73, fig. 12, cronologia de 230/360; forma $50 \mathrm{~B}$, p. 69-72, fig. 12, cronologia de 350-400 e posterior.

Prato da forma Hayes $58 \mathrm{~A}$

18 1-II-3 Fragmento do bordo e da parede. Bordo decorado com ranhuras finas. Diâm. c. $360 \mathrm{~mm}$. Est. Ill ( $\left.{ }^{40}\right)$.

Cf. Hayes, Late Roman Pottery, forma 58 A, p. 93-95, fig. 14, cronologia: de 290/300-375.

(39) Existem mais três fragmentos de bordos desta forma.

$\left({ }^{\circ}\right)$ Existem mais três fragmentos pequenos de bordos da mesma forma. 
Também a transição da TSG «C» para a «D» está assinalada no Alto do Cidreira. Vários fragmentos de bordos da forma Hayes 58 mostram uma pasta que, embora menos depurada que a da TSC $« \mathrm{C} »$, apresenta, no entanto, ainda melhor qualidade que a «D» evoluída, enquanto o engobe, fino e baço (e. g., n. ${ }^{\circ} 14-\mathrm{HH}-15$ n. i.), ou com um brilho leve (e. g., 24-IH-21 n. i.), continua pelo menos na sobeira do bordo $\left({ }^{41}\right)$.

«Terra Sigillata Clara D»

A forma Hayes 58 B de TSC «D» representa a primeira importação deste tipo de cerâmica. A pasta, com muitos grãos de tamanho pequeno ou médio, de quartzo e inclusões de calcite, tem uma variedade lata de tons, desde o laranja-claro (Munsell 2,5 YR 6/8) até ao vermelho-claro (Munsell $10 \mathrm{R} 7 / 8$ ) e a cor de tijolo

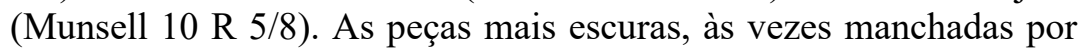
causa das temperaturas elevadas e da falta de controlo sobre a circulação do ar no forno, pertencem geralmente às formas mais tardias. $\mathrm{O}$ engobe também varia muito na sua cor, embora o laranja (Munsell 2,5 YR 6/8) seja a cor mais corrente, especialmente nas peças de cronologia mais alta. A aplicação de engobe foi quase sempre numa camada fina, com aspecto baço ou de pouco brilho.

A abundância relativa de TSC «D» (38 fragmentos) é prova da persistência e intensidade do povoamento do Alto do Cidreira até ao período romano tardio.

\section{Pratos da forma Hayes $58 \mathrm{~B}$}

Quase todos os fragmentos desta forma encontrados no Alto do Cidreira apresentam engobe nos dois lados da parede. O bordo está sempre decorado com, pelo menos, duas ranhuras finas $\left({ }^{42}\right)$.

(41) Trata-se de dois fragmentos do bordo e mais alguns da pança, pequenos demais para serem ilustrados.

(42) Além das peças enumeradas, há ainda cinco fragmentos desta forma. 
19 14-HH-10 Dois fragmentos do bordo e da parede. Engobe laranja (2,5 YR 5/8) nos dois lados da parede. Diâm. c. 360-380 mm. Est. III.

20 4-HH-15 Fragmentos do bordo e da parede. Pasta vermelho-claro (10 YR 6,5/8), engobe do mesmo tom. Diâm. c. 320 mm. N. i.

21 1-11-16 Fragmento do bordo e da parede. Desprovido de engobe no exterior da pança. Diâm. c. 300 mm. Est. III.

Cf. Hayes, Late Roman Pottery, forma 58 B, p. 93-96, fig. 14, cronologia de c. 290/300-375.

\section{Pratos da forma Hayes 59 B}

22 1-HH-2 Fragmento do bordo e da parede. Pasta cor de tijolo (10 R 5/8), engobe vermelho (10 R 5/6), aplicado apenas no bordo e no lado interior da pança. Diâm. c. 294 mm. Est. IV ( $\left.{ }^{43}\right)$.

Cf. Hayes, Late Roman Pottery, forma 59 B, p. 96-100, fig. 15, cronologia de c. 320-420.

\section{Pratos da forma Hayes 61}

Os pratos desta forma relativamente tardia já representam um fabrico um tanto degenerado. A pasta, laranja acastanhada (Munsell 2,5 YR 5/6), bastante esponjosa e groseira, contém abundantes grãos de quartzo e também feldspato, mica, glóbulos de óxido de ferro e calcite. O engobe, laranja acastanhado (2,5 YR 5,5/6) ou avermelhado (1,25 YR 6/8), é espesso e aderente e, em muitos dos casos, queimado e manchado de cinzento escuro (10 R 3/1). Em metade das peças, o engobe não foi aplicado na parede exterior, mas apenas sobre o bordo.

23 4-IH-12 Forma 61 B, fragmento do bordo e da parede. Diâm. c. 340 min. Est. IV.

24 3-IH-17 Forma 61 B, fragmento do bordo e da parede. Restaurado na Antiguidade com um gato. Est. IV.

(43) Desta forma existem mais três fragmentos de bordos, dois dos quais de pasta e engobe em tons de vermelho, o outro em tons de laranja. 
Estes dois pratos, mais dois de igual perfil, fazem parte da produção mais tardia desta forma. A sua cronologia deve caber nos fins do séc. IV ou na primeira metade do séc. v. Cf. HAYES, Late Roman Pottery, forma 61 B, p. 100-107, figs. 16 e 17; ID., Supplement, p. 516.

\section{Pratos da forma Hayes 67}

Hayes distingue três grupos diferentes nesta forma, cada um deles com fabrico típico e cronologia diferente. Pelos bordos (não se conservam os fundos decorados) podemos reconhecer dois destes fabricos entre os três fragmentos desta forma achados no Alto do Cidreira.

25 26-IH-21 Fragmento do bordo. Engobe baço, laranja (2,5 YR 5,5/8).

Diâm. c. $420 \mathrm{~mm}$. Est. IV.

Este prato pode ser integrado no primeiro grupo, datável da primeira metade do séc. iv.

26 5-HH-15 Fragmento do bordo. Engobe espesso, laranja avermelhado (1,25 YR 5/8). Diâm. c. 280 mm. Est. IV.

Outro fragmento (1-sup-81) tem engobe mais fino, de um laranja mais vivo (2,5 YR 6/8). Estes dois fragmentos pertencem ao terceiro grupo desta forma, cuja cronologia se situa a partir dos meados do séc. v. Cf. HaYes, Late Roman Pottery, forma 67, p. 112-116 , fig. 19.

\section{Tigela da forma Hayes 67/71}

27 91-HH-25 Fragmento do bordo. Pasta laranja-claro-rosada (2,5 YR 7/6) vestígios de engobe muito fino e baço, laranja-rosado. Duas ranhuras na parte superior do bordo. Diâm. c. 162 mm. N. i.

Cf. HAYEs, Supplement, p. 485 e 503; Fouilles de Conimbriga, IV, n. ${ }^{\text {os }}$ 70-74, p. 264-265, Est. LXX, cronologia: séc. iv? (p. 270). 


\section{Tigela da forma Hayes $73 \mathrm{~A}$}

28 4-IH-17 Fragmento do bordo, não conservando, porém, os entalhes caraterísticos desta forma. Diâm. $160 \mathrm{~mm}$. Est. IV.

Cf. Hayes, Late Roman Pottery, forma 73 A, p. 122-124, fig. 21, cronologia: c. 420-475; Fouilles de Conimbriga, IV, n. ${ }^{\circ} 87$, p. 257-258, Est. LXXI, uma tigela parecida, também sem entalhes no bordo, mas de fabrico TSC «C».

\section{Travessa da forma Hayes $76 \mathrm{~B}$}

29 23-1H-31 Fragmento do bordo e da parede. Pasta e engobe (este com brilho leve) de cor laranja-avermelhado (1,25 YK 6/8). Diâm. 486 mm. Est. IV.

Cf. Hayes, Late Roman Pottery, forma 76, n. ${ }^{\text {os }} 6$ e 7, p. 124-125, fig. 21; ID., Supplement, forma 76 B, p. 485-486, 504, cronologia: inícios do séc. v; Fouilles de Conimbriga, IV, n. ${ }^{\text {os }} 93$ e 95, p. $265-$ 266, 277, Est. LXXII

\section{Prato covo da forma Hayes 103 B}

30 1-II-1 Fragmento do bordo. Diâm. c. 320 mm. Est. IV.

Cf. Hayes, Late Roman Pottery, forma 103 B, p. 157-160, fig. 29, cronologia: c. 500-575.

\section{Travessa da forma Hayes 104 A}

31 4-sup-81 Fragmento do bordo. Diâm. c. 350 mm. Est. IV.

Cf. Hayes, Late Roman Pottery, forma 104 A, p. 160-166, figs. 29 e 30, cronologia: c. 530-580, ou a partir dos meados do séc. $\mathrm{V}$ (Fouilles de Conimbriga, IV, p. 270).

(44) Hayes, Late Roman Potttery, p. 115. 


\section{Pratos ou travessas de forma indeterminável}

32 1-HH-12 Fragmento do fundo com decoração estampada. Pasta laranja rosada (2,5 YR 6/6), muito bem classsiflcada, com inclusões muito abundantes (especialmente de quartzo) em fracção pequena. Engobe espesso, baço, de cor vermelho-amarelada (1,25 YR 5/6) apenas no lado de dentro. Est. IV.

A decoração estampada é dos tipos Hayes 36 e 69, ambos encontrados nas formas Hayes 61, 64 ou 67, com cronologia entre c. 350 e 450 (Hayes, Supplement, p. 516).

33 9-HH-25 Fragmento do fundo com decoração estampada. Pasta laranja amarelada (3,75 YR 7/8), semelhante à da peça anterior. Engobe muito fino mas aderente, do mesmo tom da pasta. Est. IV.

Cf. Hayes, Late Roman Pottery, p. 218-219; Id., Supplement, decoração do estilo A, de cronologia entre c. 320 e c. 450.

\section{«Late Roman C»}

Chegaram até nós três fragmentos de bordos de pratos da forma Hayes $3 \mathrm{C}$ e $3 \mathrm{E}$, do fabrico TSC de origem fócense. A pasta calcítica de cor laranja (2,5 YR 6-7/8) dos nossos excemplares assemelha-se, de resto, a este tipo de cerâmica dito «Late Roman C».

34 2-HH-3 Forma $3 \mathrm{C}$, fragmento do bordo. Vestígios de engobe na parede interior. Diâm. c. $236 \mathrm{~mm}$. Est. IV.

35 10-HI-7 Forma 3 C, fragmento do bordo. N. i.

36 Sup-77 Forma 3 E, fragmento do bordo decorado com «guilhoché» fino. Est. IV.

Cf. Hayes, Supplement, p. 525-526. ID., Late Roman Pottery, forma 3 C, p. 329,333 e 337, fig. 67-7, com cronologia entre c. 460-490; forma 3 E, p. 331, 333, fig. 68-16, dos inícios do séc. iv. 


\section{SIGILLATA CINZENTA PALEOCRISTÃ}

O razoável poder econòmico dos habitantes do Alto do Cidreira na época tardo-romana, já citado (p. 3), também se documenta com os dois fragmentos de «sigillata cinzenta paleocristã» importada da Gália.

Trata-se de um prato e de uma tigela, de pasta cinzenta-clara (10 YR 6/2), muito fina, compacta, com algumas inclusões muito pequenas de mica, visíveis com lupa de mão. As peças foram acabadas com um engobe delgado e brilhante, em cinzento muito escuro (N 3), no caso do prato, e cinzento escuro (10 YR 4/1), na tigela.

A «sigillata cinzenta paleocristã» foi produzida na Gália a partir dos fins do séc. iv e durante todo o séc. v, continuando, talvez, a sua produção no séc. vi; todavia, a data final deste fabrico ainda não foi determinada $\left({ }^{45}\right)$. $\mathrm{O}$ certo é que, no séc. $\mathrm{v}$, começou a substituir a «terra sig ilia ta» tardia e, no fundo, este tipo de cerâmica pode ser considerado uma continuação da TSC «B» $\left({ }^{46}\right)$. Havia vários centros de produção na Gália meridional; situavam-se dois na região de Narbona, merecendo Marselha um lugar especial, porque exportava os seus produtos em grandes quantidades para muitos territórios, designadamente a Hispânia $\left({ }^{47}\right)$. Hayes considera estes fabricos não só de origem mas também de cronologias diferentes; concorda, contudo que a datação das duas primeiras fases (originárias de Narbona e de Marselha) deve situar-se, respectivamente, na segunda metade do séc. iv e no séc. $\mathrm{v}$, devido à semelhança da decoração com a da TSC «D» da mesma época $\left({ }^{48}\right)$.

É, para nós, impossível saber a qual dos dois fabricos os nossos fragmentos pertencem; não podemos, por isso, precisar, por enquanto, a sua cronologia.

${ }^{(45)}$ Rigoir, Grises et Orangées, p. 177.

(46) ID., ibid., p. 179.

(47) Rigoir, Les Dérivées, p.. 35-36 e 40. Em Portugal, a «terra sigillata cinzenta» foi, até agora, assinalada em Tróia, Conimbriga e Póvoa de Cós (cf. MaIA, Troia, p. 412).

(48) Hayes, Late Roman Potery, p. 403. 


\section{Prato da forma Rigoir 8}

1 5-IH-12 Fragmento do bordo e da parede. Diâm. indeterminável. Est. IV.

Cf. Rigoir, Sigillée Grise, n. ${ }^{\circ}$ 144, p. 26, Est. VII ; Hayes, Late Roman Pottery, forma 61 A/B, n. ${ }^{\circ} 26$, p. 105-107, fig. 17. Este prato de TSC «D» tem essencialmente a forma do nosso e, sendo uma peça de transição, deve datar dos fins do séc. iv (HAYEs, Supplement, p. 516).

2 6-IH-16 Fragmento do bordo e da parede, com decoração estampada. Diâm. 130 mm. Est. IV.

A decoração está estampada em duas faixas: a superior, de rodelas com raios no centro e pontilhado à volta de círculos concêntricos; a inferior, de estrelas de David. Não conseguimos encontrar paralelos exactos para estes punções na gama de «terra sigillata cinzenta paleocristã» publicada. As rodelas podem ser confrontadas com o motivo n. ${ }^{\circ} 533$ de Rigoir, encontrado, por exemplo, numa peça de Elche - só que esse motivo apresenta doze raios, enquanto que o nosso tem dezasseis. A estrela de David parece ser motivo raro na produção de «terra sigillata paleocristã» $\left.{ }^{89}\right)$. Apenas encontramos desenho semelhante na «terra sigillata Late Roman C» usada durante os anos 440-490. Cf. Rigoir, Sigillée Grise, p. 1-91 ; forma 6, p. 25-26; motivo n. ${ }^{\circ} 39$, p. 43; RigoIR, Les Dérivées, p. 33-68; motivo n. ${ }^{\circ}$ 553, p. 46-47; Hayes, Late Roman Pottery, motivo n. ${ }^{\circ}$ 6a, do grupo II, p. 349 e 351, fig. 73.

\section{LUCERNAS}

Encontrámos apenas cinco fragmentos de lucernas, dos quais só três são mais ou menos reconhecíveis e classificáveis quanto à forma. Trata-se de fragmentos pequenos; não queremos, todavia, deixar de anotar a sua presença.

$\left.{ }^{(39}\right)$ Rigoir, Grises et Orangées, p. 203-204, o autor admite desconhecer o motivo no período paleocristão. 
1 9-IH-16 Fragmento da orla, com decoração de óvulos. Pasta fina, ocre (7,5 YR 7/4), engobe mal preservado, laranja-acastanhado. Est. II.

Este fragmento pertencia possivelmente à forma Deneauve $\mathrm{V}$ A ou V D, ou ainda ao tipo Dressel/Lamboglia 16, todos eles datáveis do séc. i. Cf. Deneauve, Carthage, n. ${ }^{\circ} 474$, p. 136. Est. L ; n. ${ }^{\text {os }} 624$, 629 , p. 156,157, Est. LXIII.

2 15-HH-5 Fragmento da orla e da asa. Asa perfurada com três ranhuras longitudinais. Vestígios de decoração de pérolas na orla. Pasta laranja-amarelada (5 YR 7/6), limpa e dura, sem engobe. N. i.

Estamos confrontados com o fragmento de uma lucerna da forma Dressel, Lamboglia 30 A ou B do séc. m. Cf. Alarcão, Lucernas romanas, n. os 27 e 28, p. 77, 85, Est. IV e V.

3 19-HG-24 Fragmento de um bico alongado. Pasta grosseira, cinzenía (N 5,5/0), sem engobe. N. i.

O bico alongado aponta para uma cronologia do séc. m ou iv.

\section{CERÂMICA FINA BRANCA}

Entre a cerâmica fina do Alto do Cidreira existem doze fragmentos de peças pequenas e bem modeladas numa pasta branca semelhante à pasta mais grosseira do fabrico emeritense de «paredes finas». A raridade destas peças, a qualidade da pasta e a sua modelação sugerem um fabrico talvez nas oficinas que produziam a própria cerâmica de «paredes finas» na região de Mérida.

A pasta é também comparável à pasta $\mathrm{H}-2$ da cerâmica procedente das necrópoles elvenses, sobre cuja possível origem e fabrico já nos debruçámos $\left({ }^{50}\right)$. Sugerimos então, como hipótese, que este fabrico se situaria, provavelmente, nos sécs. $\mathrm{n}$ e $\mathrm{m}$. Temos que admitir, agora, a possibilidade de também nos finais do séc. i se

${ }^{(50)}$ Nolen, Alto Alentejo, cf. o capítulo sobre as pastas e os n. ${ }^{\text {s }} 137$ e 138, p. 62-63, Est. XVIII. 
tornearem já peças deste tipo, a par com a própria cerâmica de «paredes finas». A bilha n. ${ }^{\circ}$, por exemplo, tem o bordo com dobra típico já do séc. i. Esta pasta «branca» de tons beje muito claros caracteriza-se pela sua cor consistente (10 YR 9/2-8/3). Trata-se de um barro fino, com abundantes grãos angulosos de quartzo, pequeníssimas inclusões de minerais ferromagnesianos, algumas de mica, feldspato e cerâmica moída, e vários pontinhos de hematite. A cerâmica moída não está presente em quantidades suficientes para se poder falar de desengordurante.

De forma reconhecível são:

1 6-HH-8 Bilha de bordo com uma dobra, fragmento do gargalo. Diâm. $66 \mathrm{~mm}$. Est. II.

Cf. Alarcão, Comum, n. ${ }^{\circ} 459$, p. 86 , Est. XXII, uma bilha com duas asas da época flávia; n. ${ }^{\circ}$ 508, p. 90 e 92, Est. XXIV, em cerâmica siltosa dos sécs. i e n ; Santrot, Aquitaine, n. ${ }^{\circ} 403$, p. 178, uma bilha encontrada em Saintes, datável dos anos 50-80.

2 13-HH-25 Mortarium pequeno ou prato covo, fragmento do bordo.

Diâm. 238 mm. Est. II.

Cf. Alarcão, Cerâmica aparentada com PF, n. ${ }^{\circ} 49$, p. 104, Est. III. Este fabrico tem integralmente uma cronologia da segunda metade do séc. i. Fouilles de Conimbriga, VI, n. ${ }^{\circ}$ 47, p. 74 e 76, Est. XVIII, uma peça encontrada na canalização do foro flávio.

3 3-GH-1 Tigela ou lamparina, fragmento do bordo. Diâm. interior do bocal $78 \mathrm{~mm}$. Est. II.

4 4-GH-1 Púcaro, fragmento do bordo. Diâm. 78 mm. Est. II.

Parece-nos tratar-se de um púcaro pequeno com duas asas, semelhantes aos tipos 1-a e 1-b de Vila Viçosa ( $\left.{ }^{51}\right)$. As duas peças do tipo 1-a foram torneadas na pasta $\mathrm{H}$, comparável à deste púcaro.

(51) ID., ibid., púcaros dos tipos 1-a e 1-b, p. 68-69, Est. XXI.

Conimbriga, 27 (1988), 61-140 
A cronologia sugerida para os dois púcaros do Alto Alentejo é a segunda metade do séc. i ou a primeira metade do séc. n.

5 5-GH-l Asa(s) com sulco longitudional, dois fragmentos isolados. N. i.

6 2-GH-1 Fundo de bilha pequena, taça ou púcaro. Diâm. do pé $34 \mathrm{~mm}$. N. I.

Este fundo e a(s) asa(s) possivelmente faziam parte do púcaro n. ${ }^{\circ} 4$.

A pasta, também branca, do seguinte vaso é essencialmente diferente da das seis peças anteriores :

7 90-GH-1 Malga ou mortarium pequeno, fragmento do bordo reentrante.

Diâm. c. 138 mm. Est. II;

A pasta branca (2,5 Y 9/2) é esponjosa, de boa classificação, com abundantes elementos não argilosos, constituída na sua maioria por quartzo em grãos rolados de tamanho médio. Ocorre também o feldspato, glóbulos ferruginosos, grãos pequenos de minerais ferro-magnesianos e grãos polimineralizados. A pasta assemelha-se à dos «almofarizes de importação» de Conimbriga ( ${ }^{52}$ ).

\section{CERÂMICA COMUM}

AS PASTAS E OS ACABAMENTOS

O exame à lupa de mão das pastas utilizadas no fabrico de cerâmica «comum» encontrada no Alto do Cidreira levou-nos a concluir que a maioria das peças são provenientes da mesma zona ou até das mesmas olarias. Elevada percentagem (c. 70\%) dos fragmentos inventariados foi fabricada a partir de pastas parecidas e relacionadas (são as pastas do nosso grupo 1). Os restantes vasos

(52) Fouilles de Conimbriga, VI, p. 71-72, trata-se de almofarizes, porém, de formas não comparáveis à $n .^{\circ} 7$, da época flávia e trajânica. 
representam, pelo menos, três fabricos diferentes, qualquer um deles sem significado numérico e, por isso, comercial, para a população da villa. Apenas podemos sugerir com certo grau de confiança a proveniência de dois fragmentos (n. ${ }^{\circ} 53$, prato de bordo reentrante, e 20-IH-21, um fragmento pequeno inédito dum jarro asado de colo aprumado - cf. $n .{ }^{\circ} 72$ da cerâmica comum). A sua pasta abundante em minerais ferro-magnesianos aponta para uma origem algures no Alto Alentejo (53). A escassez de peças desta pasta (tipo A na classificação elaborada para a cerâmica «comum» do Alto Alentejo) sublinha o que já dissemos acima (p. 4): a falta de relações comerciais entre a costa ocidental e o interior da Lusitânia.

Ainda que não possamos localizar os barreiros que deram os barros das pastas do grupo $1 \mathrm{e}$, por isso, se desconheça, por enquanto, o lugar da fabricação da maior parte da cerâmica usada na ailla do Alto do Cidreira, podemos ter a certeza de que uma tal quantidade de louça não era transportada de muito longe.

Foi-nos possível identificar os seguintes tipos diferentes de barros usados no fabrico da presente colecção de cerâmica «comum» :

Tipo 1

Trata-se de pastas depuradas a partir de um barro recolhido não muito longe da rocha-mãe. Os grão sub-angulosos ou subulados indicam que a matéria-prima sofreu uma certa acção de transporte pelas águas, embora a presença de abundante mica em algumas das peças deste grupo seja índice da desintegração recente da rocha-mãe.

Todas as pastas deste grupo se reconhecem pela presença de quartzo dominante entre os componentes não-argilosos. Encontramos também pouco feldspato e escassos grãos poliminerais (especialmente no tipo 1-a) e/ou cerâmica moída.

O grupo é divisível consoante a depuração que o barro sofreu nas mãos do oleiro :

1-a Pasta francamente grosseira, com abundantes inclusões não-argilosas, medianamente ou mal classificada, dura e esponjosa.

(53) Nolen, Alto Alentejo, p. 23-24; ID., Santo André, p. 70. 
A sua cor é laranja acastanhada (Munsell 3,75 YR-5 YR 5/6) ou castanha (Munsell 7,5 YR 4/2) até cinzenta escura (Munsell 7,5 YR 3/0) e, nalguns casos, laranja amarelada (Munsell 5 YR 7/7). São 76 os fragmentos desta pasta inventariados $\left({ }^{54}\right)$, dos quais 27 apresentam uma maior concentração de cerâmica moída e oito mostram elevado teor de mica, geralmente moscovítica. Parece ter sido a pasta preferida para modelar os potes de cozinha.

Existem ainda mais dez fragmentos numa variedade clara desta pasta (cf. o prato $n .^{\circ} 59$ e a panela $n .^{\circ} 14$ ).

1-b É a pasta mais encontrada. Sensivelmente mais fina que 1-a, com muitas inclusões não-argilosas, de tamanho médio, bem ou medianamente classificada, dura e compacta ou pouco esponjosa. A cor anda à volta do laranja-acastanhado (Munsell 5 YR 5/6), ou, mais raramente, variações desta cor que podem ir desde o laranja (Munsell 2,5 YR 6/8), ocre-alaranjado (Munsell 7,5 YR 6/5) até ao castanho escuro-alaranjado (Munsell 5 YR 4/3-4/6). Entre os 114 fragmentos examinados, encontramos alguns com abundância de pequeníssimos pontinhos de mica. Das 77 panelas inventariadas, 31 foram torneadas com esta pasta.

1-c Pasta mais depurada, com poucas inclusões não-argilosas de tamanho pequeno, bem classificada, pouco esponjosa, um tanto branda, de cor laranja (Munsell 2,5-5 YR 6/8) ou ocre-alaranjado (Munsell 6,25 YR 6/4). Foram registados 43 fragmentos desta pasta, e encontramos, mais uma vez, alguns cacos (13) com abundância de mica.

1-d Pasta comparável à 1-b, mas com cerâmica moída em quantidades que indicam um adicionamento intencional, de maneira que se pode falar de «desengordurante» para conseguir uma pasta menos plástica e mais resistente. Registamos 36 fragmentos nesta pasta.

(54) As quantidades indicadas na distribuição das várias pastas referem-se aos fragmentos (geralmente bordos, 403 ao todo) inventariados. Não fizemos um estudo nem um cálculo numérico das pastas de todos os cacos recolhidos. 
1 - b/d Outra pasta comparável à 1-b ou à 1-d, mas com reduzida quantidade de cerâmica moída. Aqui já não se trata de «desengordurante», mas sim de sujidade não intencional da olaria ${ }^{(55)}$. Classificamos 26 fragmentos desta pasta.

\section{Tipo 2}

2- a Pasta feldspática, usada de preferência para a fabricação de cântaros e dólios das épocas tardo- e pós-romanas. Trata-se de uma pasta bastante grosseira, mal ou medianamente classificada, em que o feldspato é o ingrediente mais característico e abundante. Apresenta-se em grãos de tamanho variável desde o pequeno até ao grande. $\mathrm{O}$ quartzo é em menor quantidade, apresentando grãos sub-rolados até sub-angulosos. Encontram-se também, por vezes, cerâmica moída e grãos polimineralizados em quantidades significativas. É uma pasta dura, áspera, cozida a temperaturas geralmente altas, dando tons de laranja claro (Munsell 3,75 YR 7/6) até o castanho escuro alaranjado (Munsell 5 YR 4/4), sendo, porém, mais frequente o laranja acastanhado (Munsell 5 YR 5/6). Reconhecemos 22 fragmentos nesta pasta.

2-b Pasta relacionada tanto com o tipo 2-a como com o 1-a. A quantidade de feldspato presente coloca-a entre as duas; a textura, classificação e outros ingredientes não-argilosos aproximam-na da pasta 2-a. A cor dos 19 fragmentos registados varia, mais uma vez, entre o laranja escuro (Munsell 2,5 YR 4/8) e o laranja-acastanhado (Munsell 3,75 YR 5/6), embora existam três fragmentos do bordo de um prato (e. g., n. ${ }^{\circ} 50$ com engobe vermelho), cuja cor é o ocre (Munsell 7,7 YR 7/4).

(55) A quantidade deste elemento faz pensar, todavia, que não se trata apenas de simples sujidade da olaria. Não há dúvida que o ambiente de trabalho foi diferente durante o amassar das duas pastas (1-b e 1-b/d). Será que a pasta $1-b / d$ saiu com mais «grog» nos dias em que se varria o chão e andava poeira no ar? 
Tipo 3

Pasta branda em que o elemento não-argiloso mais significativo é a cerâmica moída. Também existem muitos grãos rolados de quartzo, índice de que setrata de uma pasta transportada. Encontram-se poucos grãos de feldspato e/ou mica, enquanto a quantidade total de elementos não-argilosos pode ser desde «pouca» até «muita». A classificação é, regra geral, boa e a cor laranja-amarelada (Munsell 3,75 YR 7/8), que em dois dos seis bordos classificados (dois pratos, dois almofarizes e duas bilhas) se tornou cinzenta em forno redutor.

\section{Tipo 4}

O barro que constitui a matéria-prima desta pasta era uma argila parecida com a da pasta 1 , embora transportada pelas águas numa distância considerável antes de ser depositada no barreiro.

4-a Pasta grosseira, mal classificada, esponjosa e não muito dura. O elemento não argiloso mais significativo encontrado é, mais uma vez, o quartzo, embora aqui, ao contrário do que se passa com a pasta 1-a, em grãos francamente rolados. Difere daquela também na ausência quase total de minerais ferromagnesianos. Nos casos em que se tornou difícil diferenciar os dois fabricos (1-a e 4), o nosso critério classificativo assentou no teor destes ditos «máficos». Esta pasta pode incluir raro feldspato, grãos polimineralizados, e/ou «grog». Num total de 156 exemplares, encontramos 3 fragmentos com maior quantidade de cerâmica moída, e quatro outros mostram abundância de mica.

A cor é geralmente bastante escura: laranja-acastanhado (Munsell 5 YR 5/6) com os bordos reduzidos de cinzento escuro (Munsell 5 YR 4/1) ou mesmo preto (Munsell 5 YR 2,5/1).

4-b Versão mais depurada e mais lavada da pasta anterior. Os elementos não-argilosos são «poucos» ou «raros», de tamanho pequeno e bem classificados. Os constituintes são os mesmo da 4-a, com ausência quase total de grãos polimineralizados. Contámos sete fragmentos desta pasta com as características acima descritas. 
Outros cinco apresentam uma pasta levemente diferente, usada de preferência para potes de colo aprumado, onde se revela uma presença mais elevada de mica. Existem ainda mais dois fragmentos com «muita» cerâmica moída. As peças desta pasta (14 no total) foram geralmente cozidas num forno redutor para conserguir uma cor acinzentada escura (Munsell 10 YR 3/2).

Além dos exemplares fabricados nestas pastas existem ainda três peças (cf. o testo $n .^{\circ} 19$, o pote $n .^{\circ} 93$ e um fragmento inédito) feitas numa pasta com desengordurante abundante, constituído por cerâmica moída branca.

Fizemos uma tentativa de reconhecer e apontar quais as peças da época tardo- ou pós-romana. Foi uma tentativa que fizemos com muita hesitação e sem grande êxito; por isso, não nos atrevemos a apresentar um catálogo restrito para estes vasos, supostos tardios; consideramos menos arriscado integrá-los no catálogo geral da cerâmica comum. Como já deixámos dito, a bibliografia sobre a cerâmica desta época é ainda muito reduzida, enquanto as formas, de um modo geral, parecem continuar desde os fabricos do Baixo Império até os primeiros séculos medievais (à excepção dos potes n. ${ }^{\text {os }}$ 92-99 e dos cântaros n.os 103-107). Apenas pudemos observar as pastas, acabamentos e outros aspectos do fabrico. Assim reconhecemos quatro características que talvez sejam indicadores de um fabrico tardo- ou pós-romano :

A Um leve alisamento especialmente do bordo, com subsequente cozedura num forno relativamente quente, de maneira que as peças têm uma textura dura e o bordo reduzido de cor acinzentada $\left({ }^{66}\right)$.

B A superfície externa reduzida, de forma que as peças parecem ter levado uma aguada negra muito leve. Este efeito deve-se mais provavelmente ao alisamento da superfície, possivelmente apenas com as mãos molhadas, antes de os vasos serem cozidos, e à

(56) Cf. os n.os 3, 55, 75, 79, 87, 92 e 98. 
circunstância de, no final desta cozedura, sofrerem uma atmosfera redutora $\left({ }^{57}\right)$.

0 Uma aguada ou um engobe avermelhado ou acastanhado que difere deste acabamento encontrado em vasos da época romana $\left({ }^{58}\right)$.

D A pasta do tipo $2\left({ }^{59}\right)$.

AS FORMAS*

\section{PANELAS}

De todas as formas de cerâmica «comum» encontradas na estação do Alto do Cidreira, a panela de bordo dobrado sobre o ombro é a mais típica e a mais frequente. A forma genérica apresenta diversas variantes, sempre, porém, com o bordo relativamente largo e virado para o exterior. Foram utilizadas para servir à mesa ou, no caso das peças mais grosseiras, para cozinhar, talvez sopas ou outras comidas com molho.

Ainda que alguns dos paralelos estejam munidos com duas asas, não podemos admitir que as panelas do Alto do Cidreira fossem asadas, dada a ausência total de asas entre os achados integráveis nesta categoria; nem sequer encontrámos vestígios do seu arranque nas centenas de fragmentos examinados. Os paralelos citados para estas panelas são geralmente atribuídos ao Alto Império, desde a época de Cláudio, mas também encontramos vários exemplares do Baixo Império. Estes, mais os três fragmentos de pastas «tardo- ou pós-romanas» (n. ${ }^{\circ}$ 2, 3 e 6), indicam uma sobrevivência e uma

* Dado que estas peças de cerâmica «comum» são ilustradas quase integralmente, o leitor pode verificar no desenho o tamanho do fragmento e a parte do vaso que abrange. Por isso, não incluímos informação sobre este ponto como fizemos no caso das cerâmicas finas. O diâm. indicado é sempre o do bordo, se nada for referido em contrário. Quando falta esta dimensão, o fragmento é pequeno demais para a determinar.

(57) Cf. os n. ${ }^{\circ}$ s 2, 6, 24, 20, 30, 35, 00, 93, 94, 90, 97, 100 e 107.

(58) Cf. os n.os ${ }_{18)}{ }^{70} \mathrm{~g} 95$.

(59) Cf. os n. ${ }^{\circ}$ s 07, 70, 94 e 103-105. 
duradoura utilização desta forma. Parece-nos, contudo, ainda prematuro e arriscado tentar delinear uma evolução no perfil destas panelas, especialmente porque dispomos, por enquanto, apenas dos bordos e não há um único vaso com perfil completo. Com o material desta estação somente pudemos estabelecer uma tipologia da forma em questão o mais pormenorizada possível a fim de que, no futuro, seja possível definir uma evolução.

A pasta preferida para o fabrico das panelas era a 1-b, com 31 exemplares do total de 77 bordos inventariados; 20 peças foram torneadas nas pastas 1-a ou 1-c.

\section{Panelas de bordo simples, dobrado para o exterior}

1 29-HH-10 Pasta 1-b, diâm. 185 mm. Est. V.

2 29-GH-1 Pasta 1-b. Superfície negra, fabrico tardo ou pós-romano (B).

Diâm. 176 mm. Est. V.

3 67-GH-1 Pasta 1-a. Provavelmente de fabrico tardo-romano (A). Diâm. $162 \mathrm{~mm}$. Est. V $\left({ }^{60}\right)$.

Não nos é possível indicar paralelos da época tardo-romana para esta forma; antes pelo contrário, as peças que podemos citar indicam uma cronologia no Alto Império. Cf. Dyson, Cosa, LS 18, p. 142-143, fig. 56, do depósito 25 C 11, dos fins do séc. i-meados do séc. II (p. 139); Silva, Alcácer do Sal, n. ${ }^{\circ} 303$, p. 201, fig. 24, da segunda metade do séc. i-inícios do séc. n; Mezquiriz, Pompado, II, n. ${ }^{\circ} 8$, fig. 73 , de Arcedianato, Sector D-E, estrato V, dos fins do séc. I.

Panelas de bordo ligeiramente engrossado, dobrado para o exterior, formando aba horizontal

4 40-HH-25 Pasta 1-c micácea. Diâm. 192 mm. Est. V (61).

Cf. Alarcão, Comum, n. ${ }^{\circ} 415$, p. 84, Est. XX, da cerâmica do Alto Império, encontrado em estratos trajânicos; MESQUiRIZ,

$\left({ }^{60}\right)$ Outros exemplares semelhantes (de pasta 1-b) têm entre 182 e 188 mm de diâm. (três peças), ou de 210 a $222 \mathrm{~mm}$ (duas peças). $220 \mathrm{~mm}$.

(61) Quatro exemplares semelhantes (de pasta 1-b) têm diâm. entre 196 e 
Pompetelo, II, n. ${ }^{\circ}$ 94, fig. 118, da Plaza de San José, estrato IV, do séc. i, encontrado, contudo, com moedas tardo-romanas.

\section{Panelas como a anterior, mas de bordo francamente engrossado} e parede geralmente aprumada

5 65-GH-1 Pasta 1-b. Diám. 270 mm. Est. V.

6 1l-HG-24 Pasta 1-b, superficie negra. Fabrico tardo ou pós-romano (B).; Diám. 220 mm. N. i.

7 18-HH-5 Pasta 1-c. Diám. 122 mm. Est. V (62).

Trata-se de urna forma já conhecida do séc. n. Cf. Alarcão, Comum, n. ${ }^{\circ}$ 600, p. 93-95 e 99, Est. XXVIII, da cerâmica alaranjada fina do Alto Império, encontrada em níveis trajânicos.

\section{Panelas de bordo engrossado e dobrado para o exterior,} formando urna aba descaída

8 1-HH-5 Pasta 1-b. Ftanhura na parte superior do bordo. Diám. $152 \mathrm{~mm}$. Est. V ( $\left.{ }^{63}\right)$.

Panelas de bordo engrossado, dobrado para o exterior e cavado na parte superior

9 3-HH-8 Pasta 1-a com elevada presença de cerâmica moída. Diam. $194 \mathrm{~mm}$. Est. V ( $\left.{ }^{64}\right)$.

Cf. Alarcão, Comum, n. ${ }^{\circ}$ 353, p. 79, Est. XVII, da cerâmica alaranjada média do Alto Império, encontrado em canos da época fJávia; Nolen, Santo André, n. ${ }^{\circ}$ I 2-11, p. 109-110, Est. LVII, de uma sepultura dos primeiros anos do séc. n (p. 134).

(62) Outros exemplares semelhantes (de pasta do grupo 1 e de 4-b) têm diâm. entre c. 158 e c. $270 \mathrm{~mm}$ (cinco peças) ou de c $120 \mathrm{~mm}$ (duas peças).

(63) Outros exemplares semelhantes (de pasta do grupo 1) têm diâm. entre 180 e $220 \mathrm{~mm}$ (nove peças) ou de 148 a $168 \mathrm{~mm}$ (seis peças).

(64) Cinco exemplares semelhantes (de pastas do grupo 1) têm entre $156 \mathrm{e}$ c. $200 \mathrm{~mm}$ de diâm. 
Panelas de bordo ligeiramente engrossado, dobrado para o exterior e coin canelura(s) na parte superior

10 2-11-1 Pasta 1-b. Diâm. c. 180 mm. Est. v((65).

Cf. Alarcão, Comum, n. ${ }^{\circ}$ 352, p. 79, Est. XVII, da cerâmica alaranjada, de meados do Alto Império, encontrado em estratos trajânicos e do séc. iv; Dyson, Cosa, LS 20, p. 143, fig. 56, do depósito 25 CI, dos fins do séc. i até inícios do séc. m (p. 139).

Panelas com bordos de secção semicircular

11 39-HH-25 Pasta 1-b. Diâm. 142 mm. Est. V (66).

Cf. Dyson, Cosa, LS 22, p. 143, fig. 56, do depósito $25 \mathrm{Cl}$, dos fins do séc. i até inícios do séc. m (p. 139).

Panelas com bordo de secção amendoada

12 106-HH-25 Pastai. Diâm. c, 160 mm. Est. V( $\left.{ }^{67}\right)$.

Cf. Mezquiriz, Pompaelo //, n. ${ }^{\circ}$ 1, fig. 51, de Arcedianato, sector A, estrato III, do séc. m.

\section{Panelas de bordo dobrado sobre o ombro}

13 27-IH-21 Pasta 1-a, com elevado teor de cerâmica moída. Diâm. 172 mm. Est. VI.

lá 6-IH-16 Pasta de uma variedade clara de 1-a (laranja-rosada clara

2,5 YB 7/6, veja infra o prato n. ${ }^{\circ}$ 59). Diâm. $168 \mathrm{~mm}$. N. i.

Ambas apresentam pastas grosseiras e cozidas a temperaturas elevadas num forno mal regulado, de maneira que a superfície está

(65) Dois exemplares semelhantes (de pasta 1-a) têm diâm. de $148 \mathrm{~mm}$ ou diâm. indeterminável.

(66) Cinco exemplares semelhantes (de pastas do grupo 1) têm diâm. entre 140 e $214 \mathrm{~mm}$.

(67) Outros exemplares semelhantes (de pastas 1-a e de uma variedade clara desta, cf. a panela n. ${ }^{\circ}$ 14) têm diâm. entre 186 e c. $200 \mathrm{~mm}$ (duas peças). 
manchada e áspera. Podemos atribuir-lhes uma cronologia do Baixo Império, embora com antecedentes no Alto Império $\left({ }^{68}\right)$.

Panela ou terrina de bordo pequeno, dobrado para o exterior formando aba horizontal ou descaída.

15 21-GH-1 Pasta 1-b. Diâm. 138 mm., alt. reconstituída 96 mm.

Est. VI( $\left.{ }^{69}\right)$.

Cf. Alarcão, Comum, n. ${ }^{\circ}$ 694, p. 110-111, Est. XXXIII, de cerâmica calcítica tardo-romana, encontrado em níveis dos sécs. III-V.

\section{TACHOS}

Outra forma aberta que fazia parte da louça da cozinha antiga era o tacho com moldura ou ranhura no dorso do bordo para assentamento do testo. $\mathrm{Na}$ escavação do Alto do Cidreira encontrámos bordos de apenas três exemplares e um único fragmento do bordo de um testo. O tacho para cozidos parece, pois, ter sido pouco usado no Cascais romano.

Tacho de bordo amendoado e cavado no dorso

16 12-HH-10 Pasta 1-d. Diâm. 240 mm. Est. VI.

Cf.. Perichon, Céramiques Domestiques, tipo 5-d, p. 93, Est. 36-2, do segundo período de Roanne Gilbertès, i. e, do último terço do séc. i a. C.; Nolen, Alto Alentejo, n. ${ }^{\circ} 414$, p. 108, 213, Est. XL, com cronologia sugerida da segunda metade do séc. i, até inícios do séc. II ; Mayet, Sigillées Hispaniques, n. ${ }^{\circ} 194$ da forma Dragendorff 44, p. 75, Est. LXXII, uma forma que Mayet data à volta dos meados do séc. II.

(68) Silva, Alcácer do Sal, n. ${ }^{\circ} 305$, p. 201, fig. 24, da segunda metade do séc. i ou inícios do séc. II. Dois exemplares semelhantes (de pastas 1-a e 1-b) têm diâm. de $189 \mathrm{~mm}$ ou diâm. indeterminável.

(69) Três exemplares semelhantes (de pastas 1-b e 4-a) têm diâm. entre 144 e $173 \mathrm{~mm}$.

Conimbriga, 27 (1988), 61-140 
Tacho de bordo alto, soerguido, com sulco fundo no dorso

17 6-II-16 Pasta 1-a micácea. Diám. 202 mm. Est. VI.

Cf. Alarcão, Comum, n.os 732 e 733, p. 112-114, Est. XXXV, XXXVI, de grés, tardo-romano; o n. ${ }^{\circ} 732$ de níveis do séc. v. Esta forma também se encontra na época medieval, na Gália; Cf. Bazzana, Santa Fé, n. ${ }^{\circ}$ 104, p. 295, ñg. 31-3 ; n. ${ }^{\circ}$ 176, p, 309, fig. 46-2. Vários destes paralelos ainda conservam os arranques de duas asas; o nosso fragmento $n .^{\circ} \mathbf{1 7}$ é pequeno demais para se assegurar se era ou não asado.

Tacho de bordo amendoado com sulco no topo (para segurar o testo?)

18 78-GH-1 Pasta 1-b, aguada avermelhada, queimada cinzenta na parede exterior. Fabrico tardo- ou pós-romano (C). Diám. c. 260 mm. Est. VI.

Esta forma tem antecedentes na época romana, tanto na cerâmica comum como na TSC «D». Cf. Vegas, Comum, tipo 5, n. ${ }^{\circ}$, p. 22-25, fig. 6, de Barcelona, dos sécs. II-III; HAYEs, Late Roman Pottery, forma 197, p. 209, fig. 36, dos fins do séc. $n$ até meados do séc. ni ; Mesquiriz, Pompaelo, II, n. ${ }^{\circ}$ 61, fig. 108, de Plaza de San José, estrato III, urna camada remexida da época tardo-romana; ID., ibid, $\boldsymbol{n}{ }^{\circ}$ 85, fig. 117 , de Plaza de San José, estrato IV, do séc. i, embora encontrado associado a moedas tardo-romanas.

\section{TESTO}

O fragmento da tampa $n .^{\circ} 19$ (pasta única com desengordurante constituido por cerámica branca moída, veja o pote $n .^{\circ} 93$ ) é pequeno demais para lhe acertar a inclinação; por isso, não podemos apresentar um perfil fidedigno. Era de forma cónica, de bordo simples arredondado, forma que, porter sido utilizada durante toda a época romana, não justifica a citação de paralelos com cronologia delimitada. Também se documenta, na Idade Média, na Gália. Cf. Nolen, Santo André, vários exemplares, p. 100-101; Azuar Ruiz, Castilllo del Rio, n. ${ }^{\circ}$ 69, p. 318, fig. 11. 


\section{SUPORTE}

Os fundos dos tachos e das panelas eram, frequentemente, arredondados. Para lhes dar estabilidade usavam-se, às vezes, argolas redondas de cerámica. Suportes deste tipo eram também utilizados nos fornos das olarias para separar as diferentes peças e assegurar, assim, uma melhor circulação do calor. O nosso exemplar não mostra a descoloração que seria de esperar numa peça que ia ao forno repetidamente. Estes suportes são pouco frequentes e, enquanto vasos sem pé moldurado, têm, muitas vezes, origem pré-romana; não é pois, de estranhar que os dois paralelos encontrados na bibliografia portuguesa sejam também peças de cronologia alta. A pasta de argola de Alto do Cidreira, no entanto, não nos parece pré-romana mas sim do Alto Império.

20 1-HH-22 Pasta 1-b. Diâm. 164 mm. Est. VI.

Cf. Fouilles de Conimbriga, VI, n. ${ }^{\circ} 46$, p. 8 e 10, Est. II, de cerâmica pré-romana pintada; SAntos Rocha, Figueira, n. ${ }^{\circ}$ 165, p. 65, Est. XVIII; n. ${ }^{o s} 255$ e 256, Est. XXIII.

\section{TERRINAS}

Enquanto as panelas e os tachos são formas abertas que foram usadas na cozinha e que até podiam ir ao lume durante a preparação das refeições, as terrinas, de forma aparentada mas de fabrico mais requintado, serviam para levar a comida à mesa. Todas as terrinas encontradas no Alto do Cidreira são de um tipo semelhante, cujo bordo lembra o das panelas. Era, todavia, uma forma pouco procurada, se atendermos a que nos restam fragmentos de apenas cinco exemplares. Ou será que, na humilde villa cascaense, as panelas em que a comida foi cozinhada iam também à mesa para a servir? 


\section{Terrinas de bordo descaído para o exterior}

21 10-IH-12 Pasta 1-b, decoração brunida na pança. Diâm. 192 mm.

Est. VI.

22 2-IH-16 Pasta 1-d. Diâm. 186 mm. Est. VI $\left({ }^{70}\right)$.

Cf. Gose, Gefässtypen, n. ${ }^{\text {os }} 494$ e 495, p. 42, Est. 47, a primeira de Trier e datada do último terço do séc. i, a segunda também de Trier e datada do primeiro terço do séc. II; Nolen, Santo André, n. ${ }^{\circ}$ C 5-4, p. 109-110, Est. VII, de um enterramento dos últimos anos do séc. i (p. 131).

\section{TIGELAS}

As tigejas relativamente grandes encontradas com uma certa frequência no Alto do Cidreira serviam, talvez, tal como as panelas, para preparação e simultaneamente para servir a comida, neste caso comida fria, não cozinhada.

A par das formas aqui representadas, acharam-se mais três peças de bojo arredondado (pasta 1-b e c), decoradas com ranhuras finas. Mas delas apenas nos restam fragmentos de pança pequenos demais para lhes podermos desenhar o perfil.

É de notar que as tigelas carenadas são as mais frequentes e que a sua forma baixa e aberta faz lembrar a forma Hayes 14 de TSC «A».

\section{Tigelas carenadas de lábio biselado}

23 28-IH-16 Pasta 2-b, bem depurada. Diâm. 170 mm. Est. VI( $\left.{ }^{71}\right)$.

Cf. Hayes, Late Roman Pottery, forma 14 A, p. 39-41, fig. 66-14, dos meados do séc. II; Santrot, Aquitaine, n. ${ }^{\circ} 139$, p. 94, com

$\left.{ }^{(70}\right)$ Outros exemplares semelhantes (de pastas 1-d, 2 e de uma pasta única, dura, em que a mica constitui o elemento não argiloso dominante, vide o prato.$^{\circ}$ 61) têm diâm. de c. $260 \mathrm{~mm}$ (duas peças, das quais uma possivelmente tardo- ou pós-romana), ou indeterminável (uma peça).

${ }^{(71)}$ Outro exemplar de pasta 1-b tem diâm. não determinável, e um terceiro, de pasta $1-c$, tem c. $150 \mathrm{~mm}$ de diâm. 
cronologia indicada da segunda metade do séc. i; Vegas, Comum, tipo 9 , n. ${ }^{\circ}$ 4, p. 35-37, fig. 11, com decoração brunida: esta peça, encontrada em Polentia, tem cronologia associada da segunda metade do séc. m ou do séc. iv; Alarcão, Comum, n. ${ }^{\circ}$ 627, p. 93-94 e 106, Est. XXIX, da cerâmica alaranjada fina do Baixo Império, encontrado nos canos das termas trajânicas e em níveis do séc. v.

\section{Tigelas carenadas de bordo boleado e arredondado}

24 6-HH-2 Pasta 1-c. Superfície negra, fabrico tardo ou pós-romano (B).

Diâm. 234 mm. Est. VII ( $\left.{ }^{72}\right)$.

Cf. Santrot, Aquitaine, n. ${ }^{\circ} 159$, p. 100 ; esta forma foi documentada em Bordéus numa pasta grosseira, datável dos anos 70-90, e também numa pasta depurada, de Plassac, dos sécs. iv ev.

Tigelas carenadas com bordo em forma de aba soerguida

25 27-HH-25 Pasta 1-d, engobe laranja-acastanhado (5 YR 6/6) na parte superior do bordo. Diâm. 154 mm. Est. VII $\left({ }^{73}\right)$.

2G 62-GH-1 Pasta 1-a, superfície negra, fabrico tardo ou pós-romano (B).

Diâm. 144 mm. N. i.

Cf. Alarcão, Comum, n. ${ }^{\circ}$ 456, p. 986, Est. XXII, da cerâmica calcítica do Alto Império, encontrada numa camada flávia. Também semelhantes são as formas Dragendorff $46 \mathrm{em} \mathrm{TSH}$ dos meados até aos fins do séc. $\mathrm{n}$ ou a forma Hayes $70 \mathrm{em}$ TSC $« \mathrm{C} »$ tardia de inícios do séc. v (cf. HAyes, Late Roman Pottery, forma 70, n. ${ }^{\circ} 7$, p. 119, fig. 20).

(72) Outro exemplar semelhante, de pasta 4-a micácea, tem diâm. de $196 \mathrm{~mm}$, e é de fabrico tardo- ou pós-romano.

(73) Também encontramos dois fragmentos minúsculos (ambos de pasta 1b) de um bordo sobre o quadrado, talvez pertencentes a uma ou duas tigelas carenadas (diâm. indeterminável, n. i.). 
Tigela carenada com pe alto, moldurado

27 6-HG-23 Pasta 2-a, bem classificada. Diâm. 140 mm. Est. VII.

Esta tigela faz lembrar a forma Dragendorff 33 em TS que geralmente tem cronologia da segunda metade do séc. i; mas também foi encontrada em Conimbriga em depósito trajânicos (cf. Fouilles de Conimbriga, IV, p. 185).

\section{Tigelas de perfil arredondado}

28 14-HG-24 Pasta 1-b/d, parede exterior alisada. Diâm. c. 180 mm. Est. VII $\left({ }^{74}\right)$.

E mais provável que esta peça seja de fabrico tardo-romano. Estas tigelas, de forma corrente, deviam ter tido boa procura em todas as épocas, romana ou pós-romana.

\section{ALMOFARIZES E ALGUIDARES}

Enquanto as tigelas eram usadas para preparar e/ou apresentar comidas em quantidade relativamente pequena, os alguidares $\mathrm{e}$ almofarizes, de tamanho geralmente bastante maior, serviam na cozinha para amassar, lavar hortaliças, lavar louça ou até roupa, e para todos os outros fins a que, hoje em dia, se destinam, os alguidares de plástico. Foram achados no Alto do Cidreira muitos exemplares, ou melhor, fragmentos que representam muitos exemplares, de maneira que poderíamos interrogar-nos acerca da existência local de alguma pequena indústria artesanal na época romana. Uma simples peixaria já podia explicar a presença de, ao menos, vinte e sete almofarizes ou alguidares numa estação relativamente pequena.

Apenas um destes almofarizes (n. $\left.{ }^{\circ} 37\right)$ apresenta vestígios de vertedoiro que, sem dúvida outros devem ter tido.

(74) Dois exemplares semelhantes (de pasta 1-b e de uma pasta única com desengordurante de cerâmica branca moída) têm 176 e 198 mm de diâm.

Conimbriga, 27 (1988), 61-140 


\section{Almofarizes com bordo em forma de aba horizontal ou ligeiramente curvada}

29 21-HH-5 Pasta 1-d. Diâm. não determinável. Est. VIL

30 14-GH-1 Pasta 1-b, superficie negra. Fabrico tardo ou pós-romano (B). Diâm. 360 mm. Est. VII (7ñ).

Cf. Diogo, Enchurrasqueira e Cepa, n. ${ }^{\circ} 4$, p. 214, Est. III, encontrado nos fornos de vale da Cepa, junto com ânforas das formas Dressel 14/Beltrán IV e Almagro 51-C dos séc. i e n, e m-iv, respectivamente. Para o n. ${ }^{\circ} 2$ em especial: Alarcão, Comum, n. ${ }^{\text {os }}$ 390 e 391, p. 81-82, Est. XVIII, XXI, da cerámica calcítica do Alto Império, encontrado em camadas flávias. Para o n. ${ }^{\circ} \mathbf{3 0}$ em especial : Mezquiriz, Pompaelo, II, n. ${ }^{\circ}$ 19, fig. 76, de Arcedianato, sector F-G, estrato II, dos sécs. iv e v.

Um almofariz de bordo como o n. ${ }^{\circ} 29$, mas de parede recta (27-HH-10, n. i.) encontra paralelo num exemplar procedente de Sutri, datável dos anos 60-70 (76), e num outro da Aquitánia dos sécs. II e ni $\left({ }^{77}\right)$.

\section{Almofariz de bordo em forma de aba soerguida}

31 27-IH-16 Pasta 1-b. Diâm. 430 mm. Est. VII ( $\left.{ }^{78}\right)$.

Cf. Almeida, Monte Mozinho, 1974, n. ${ }^{\circ} 3$, p. 22, Est. VII; vide também: Mezquiriz, Pompaelo, II, n. ${ }^{\circ} 19$, fig. 76, de Arcedianato, sector FG, estrato II, dos sécs. iv e v, citado sob n. ${ }^{\circ} \mathbf{2 9}$.

(75) Existem outros exemplares semelhantes (de pastas 1-ced, 4-a e b) de c. 300 a c. $400 \mathrm{~mm}$ de diâm. (três peças, uma das quais com aguada negra (?) de fabrico tardo- ou pós-romano) e outros três de diâm. indeterminável. c. $60-70$.

(76) Vegas, Común, tipo 13, n. ${ }^{\circ}$ 4, p. 41-43, de Sutri, com cronologia de

(77) SAntrot, Aquitaine, n. ${ }^{\circ}$ 189, p. 112-113, encontrado em vários sítios, com cronologia desde o séc. i até ao séc. ui.

( $\left.{ }^{78}\right)$ Três exemplares semelhantes (de pastas 1-b e d) têm entre 290 e c. $360 \mathrm{~mm}$ de diâm. 


\section{Almofariz de bordo engrossado}

82 37-IH-21 Pasta 1-c. Diàm. 421 mm. Est. VII.

Cf. Diogo et alii, Enchurrasqueira, n. ${ }^{\circ} 41$, p. 13, Est. V, de um conjunto de material datado entre os meados do séc. i e os meados do séc. II (p. 6).

Almofariz de bordo em forma de aba boleada

88 36-IH-16 Pasta 1-d. Diâm. c. 426 mm. Est. VII.

Almofarizes de bordo em seç̧ão de «T», frequentemente decorado com ranhuras ou sulcos na parte superior

84 8-FG-24 Pasta 1-b. Diâm. 285 mm. Est. VII.

35 11-HH-25 Pasta 1-a, superfície negra, fabrico tardo-romano (B).

Diâm. c. 420 mm. N. i.

36 12-HH-25 Pasta 1-c. Diâm. c. 330 mm. Est. VII.

Cf. para o n. ${ }^{\circ}$ 34: Vegas, Común, tipo 7, n. ${ }^{\circ}$ 9, p. 28-34, fig. 10, de Tarragona, com cronologia da segunda metade do séc. iv; Alarcão, Comum, n. os 926, 926 C e 927, p. 126-127, Est. LUI, de cerâmicas quartzíticas e calcíticas com ilite, dos sécs. iv e v, encontrados em níveis da ocupação visigòtica; Mezquiriz, Pómpetelo, II, $\mathrm{n} .{ }^{\circ} 10$, fig. 87 , de Arcedianato, sector $\mathrm{K}$, estrato I, encontrado com material tardo-romano até medieval (p. 132). Cf. para os n.os 35 e 36: SAntrot, Aquitaine, n. ${ }^{\circ} 186$, p. 111, da segunda metade do séc. $\mathrm{i}, \mathrm{n} .^{\circ} 205$, p. 117 , da segunda metade do séc. i (da Alemanha) até ao séc. n (de Inglaterra); Alarcão, Comum, n. ${ }^{\circ} 688$ e 689, p. Ili, Est. XXXII, de cerâmica calcítica, encontrados em depósitos do séc. v; Mezquiriz, Pompaelo, II, n. ${ }^{\circ}$ 20, fig. 102, da Plaza de San José, estrato II, um estrato remexido tardo-romano/ /medieval (p. 195).

( $\left.{ }^{79}\right)$ Três exemplares semelhantes (de pastas 1-b e d, 4-a micácea) têm entre c. 320 e c. $420 \mathrm{~mm}$ de diâm. 
Almofarizes de bordo em secção de «T» achatado, com vertedoiro

87 23-GH-24 Pasta 2-b. Diàm. c. 360 mm. Est. VII.

Este é, como dissemos, o único almofariz do Alto do Cidreira em que foi possível reconhecer o vertedoiro. Cf. Santrot, Aquitaine, n. ${ }^{\circ}$ 207, p. 117-118, de Bordéus, da segunda metade do séc. i; Stuart, Gewoon Aardewerk, tipo 210, B, n. ${ }^{\circ} 350$, p. 77-79, Est. 21, de c. 70-105; AlmeIDA, Monte Mozinho, 1974, n. ${ }^{\circ}$ 1, p. 12, Est. IX.

Alguidar de parede recta, bordo em forma de aba curta

88 1-GH-20 Pasta 1-d. Diâm. 370 mm. Est. Vili ( $\left.{ }^{80}\right)$.

Cf. Almeida, Monte Mozinho, 1974, n. ${ }^{\circ} 11$, p. 16, Est. VII.

Alguidares semelhantes, aliás de bordo mais pequeno ( $\left.{ }^{81}\right)$ encontram paralelos dos fins do séc. $\mathrm{i}$ até meados do séc. II na Cartuja. Cf. Serrano Ramos, Cartuja, n. ${ }^{\text {os }} 41$ e 43, p. 247, 257, fig. 6.

Alguidar de parede ligeiramente reentrante

39 97-HH-25 Pasta 3. Diâm. 210 mm. Est. Vili ( $\left.{ }^{82}\right)$.

Será este um «tacho» da forma 722 de Conimbriga? Cf. Alarcão, Comum, n. ${ }^{\circ}$ 722, p. 113, Est. XXXV, de uma camada do séc. $\mathbf{V}$.

\section{PÚCAROS E COPAS}

As terrinas e tigelas utilizavam-se para servir comidas sólidas, enquanto estes vasos mais pequenos levavam à mesa molhos e outros alimentos líquidos, além de servirem para beber água ou vinho.

(80) Outro exemplar semelhante (de pasta 1-b/d) tem c. $320 \mathrm{~mm}$ de diâm.

(81) Existem três exemplares de diâm. entre c. 200 e c. $340 \mathrm{~mm}$.

(82) Outro exemplar, também de pasta 3, tem diâm. de $188 \mathrm{~mm}$. 
Existem púcaros (de colo constrito) e copas (de bocal relativamente mais largo) de variadas formas, ligeiramente diferenciadas pelo feitio do bordo, mas, sem dúvida, de uso igual.

Púcaros de duas asas e bordo arqueado para o interior

40 16-HH-25 Pasta 1. Diâm. 71 mm. Est. Vili.

41 4-IH-21 Pasta 1-a com elevado teor de cerâmica moída, vestígios de engobe avermelhado. Diâm. c. 100 mm. N. i. ( $\left.{ }^{83}\right)$.

Cf. Nolen, Santo André, n. ${ }^{\text {os }} 2$ e 3 da sepultura C 3, p. 87-88, Est. V, de um enterramento datável da segunda metade do séc. i até aos inícios do séc. n (p. 139) ; ID., Alto Alentejo, tipo púcaros 1-b, p. 69, Est. XXI, datado dos fins do séc. i ou da primeira metade do séc.

\section{Púcaro de bordo contracurvado}

42 14-IH-21 Pasta 1-c micácea. Diâm. 116 mm. Est. Vili $\left({ }^{84}\right)$.

Cf. Alarcão, Comum, n. ${ }^{\circ}$ 497, p. 90-91, Est. XXIII, de cerâmica siltosa do séc. i e inícios do séc. n, encontrado em estratos trajânicos: Nolen, Santo André, n. ${ }^{\circ}$ C 8-5-a e F 3-8, p. 90-91, Est. X e XLIV, ambos de enterramentos dos fins do séc. i ou inícios do século seguinte (p. 133); ID., Alto Alentejo, tipo púcaros 3-c, n. ${ }^{\circ} 204$, p. 75, Est. XXVII, de cronologia muito incerta desde a segunda metade do séc. i até possivelmente ao séc. iv.

\section{Copa de bordo recto e evasado}

43 10-II-1 Pasta 4-a, com elevada presença de cerâmica moída. Diâm. $124 \mathrm{~mm}$. Est. Vili.

Esta copa tem bojo relativamente baixo em comparação com peças semelhantes do Alto Alentejo ou de Conimbriga; parece nitidamente de ambiente comercial diferente do daquelas regiões.

(83) Outro exemplar semelhante (de pasta 1-b) tem $112 \mathrm{~mm}$ de diâm.

( $\left.{ }^{84}\right)$ Outro exemplar semelhante (de pasta 1-b/d) tem $78 \mathrm{~mm}$ de diâm. 
A forma genérica podia ser confrontada com: Fouilles de Conimbriga, VI, n. ${ }^{\circ}$ 1-c, p. 61-63, Est. XIV, de cerâmica com engobe branco do período de Cláudio-Trajano; Nolen, Santo André, n. ${ }^{\circ}$ I 1-2, p. 90-91, Est. LV, de um enterramento da segunda metade do séc. i ou dos inícios do século seguinte (p. 132).

Copa de bordo em forma de aba curta horizontal, colo alto

44 6-GH-14 Pasta 1-c. Diâm. c. 100 mm. Est. Vili.

Cf. Alarcão,Comum, n. ${ }^{\circ}$ 55, p. 93-96, Est. XXV, de cerâmica alaranjada fina do Alto Império, encontrado fora de contexto datável; Nolen, Alto Alentejo, tipo púcaros 1-f, p. 72-73, Est. XXVI, com cronologia indicada da época flávia e da primeira metade do séc. II.

\section{$\operatorname{COPOS}$}

O copo de bojo alto era uma forma relativamente frequente no Alto do Cidreira. A sua ocorrência numérica não é tão elevada como, por exemplo, a das tigelas; em comparação, porém, com outras estações parece ser uma das formas mais típicas no presente conjunto de cerâmica comum. Residirá aqui a explicação para a ausência de copos de vidro, «paredes finas» ou «terra sigillata»? Infelizmente, só podemos apresentar dois exemplares; os restos dos outros dez estão de tal maneira esmigalhados que nos foi impossível reconhecer-lhes o perfil com certo pormenor.

\section{Copos altos de bordo amendoado}

45 24-HH-5 Pasta 1-c. Diâm. 84 mm. Est. Vili.

46 17-IH-17 Pasta 1-c. Diâm. c. 90 mm. Est. Vili $\left({ }^{85}\right)$.

Os paralelos de Conimbriga datam de vários períodos: o copo, forma tão útil, parece ter sido fabricado em todas as épocas daquela

(85) Seis exemplares semelhantes (de pastas do grupo 1) têm diâm. entre 82 e c. $90 \mathrm{~mm}$. 
cidade. Tirando esses, não encontramos formas parecidas noutras colecções publicadas de cerâmica da Lusitânia. Cf. Alarcão, Comum, n. ${ }^{\circ}$ 1, 31, 200 e 933, as primeiras três peças encontradas em estratos flávios e/ou trajânicos, a última de «fabrico tardo-romano», vide p. 43-44, 45-46, 62 e 132, Est. I, II, X, e LUI; Mezquiriz, Pompado, II, n. ${ }^{\circ}$ 26, fig. 76, de Arcedianato, sector F-G, estrato II, dos sécs. IV e v.

Existem ainda dois bordos de copos ou potinhos:

47 107-HH-25 Pasta 1-b. Bordo espalhado com diâm. de c. $30 \mathrm{~mm}$. N. i. $\left({ }^{86}\right)$.

48 7-HH-10 Pasta 1-b. Bordo de rolo com diâm. de c. 110 mm. N. i.

\section{PRATOS, TRAVESSAS E FRIGIDEIRAS}

Visto que não nos foi possível reconstituir o perfil completo de um único prato do Alto do Cidreira, não podemos ter a mímina certeza quando é que um bordo preservado pertencia a um prato ou a uma frigideira com fundo raso e queimado pelo fogo. As frigideiras tinham, em geral, bordo envasado de maneira que, no grupo dos n.os 51-54 ou 62-66, algumas das peças podiam ter sido levadas ao lume. No entanto, podemos apontar o grande predomínio nesta estação de pratos com bordo envasado, seja devido a uma contracurva da parede (n. ${ }^{\text {os }} 51-55$ ), seja devido ao lábio engrossado do lado interior (n. ${ }^{\text {ss }} 49,50,57,62,63,65$ e 66).

Como já anotámos na publicação dos pratos de Santo André e dos provenientes das necrópoles alto-alentejanas $\left({ }^{87}\right)$, a cronologia das suas formas é ainda muito imprecisa e duvidosa. Os paralelos que podemos apresentar agora continuam a dar épocas largas para o uso das respectivas formas. Temos de concluir que cada tipo genérico tinha a sua utilidade própria, e que, enquanto obedecia a este fim, continuava a ser procurado durante uma época muito lata. As peças de fabrico tardo- e pós-romano são testemunhos da continuação das formas básicas.

(86) Alarcão, Comum, n. ${ }^{\text {os }} 512$ e 513, p. 90-92, Est. XXIV.

${ }^{\left({ }^{87}\right)}$ Nolen, Santo André, p. 97; ID., Alto Alentejo, p. 81. 
Separamos os pratéis, pratos e travessas segundo o critério arbitrário do tamanho. São pratéis as peças com diâm. até $150 \mathrm{~mm}$; os pratos vão de 150 até $250 \mathrm{~mm}$ de diâm. máximo, e as travessas têm aquela medida a partir de $250 \mathrm{~mm}$.

Pratos de parede oblíqua e lábio simples, arredondado, como os tipos 4-7 de Santo André ( $\left.{ }^{88}\right)$, ou os tipos 4 e 5 do Alto Alentejo ( ${ }^{89}$ ), quase não se encontram entre a cerâmica do Alto do Cidreira. Apenas oito peças $\left({ }^{90}\right)$ entre os 64 bordos inventariados podem ser classificados como tais.

\section{Pratéis de bordo engrossado e descaído para o exterior}

49 74-GH-1 Pasta 1-b, diâm. 138 mm. N. i.

50 6-IH-17 Pasta 2-b, de cor ocre, vestígio de aguada alaranjada. Diâm.

c. $148 \mathrm{~mm}$. Est. Vili ( $\left.{ }^{91}\right)$.

Os paralelos que conseguimos mostram, aliás, o lado interior do bordo biselado. Cf. Alarcão, Comum, n. ${ }^{\circ} 485$, p. 90-91, Est. XXIII, de cerâmica siltosa do séc. i e inícios do séc. n. encontrado em estratos trajânicos, n. ${ }^{\circ} 632$, p. 93-94e 106, Est. XXIX, deceràmica alaranjada fina tardo-romana, encontrado em níveis do séc. v; Nolen, Santo André, tipo 2, n. ${ }^{\circ}$ E 5-8 e I 3-2, de sepulturas datadas dos fins do séc. i-inícios do séc. n (vide p. 93, 132-133, Est. XXXV e LVII) ; Mezquiriz, Pompado, II, n. ${ }^{\circ}$ 84, p. 206, fig. 117, de Plaza de San José, estrato IV, do séc. i, encontrado todavia com moedas tardo-romanas.

\section{Travessas e pratos de parede reentrante}

51 50-GH-1 Pasta 1-a, engobe vermelho (10 R 4/5), fino e baço, nos dois lados da parede. Diâm. c. $280 \mathrm{~mm}$. N. I.

(88) ID., Santo André, p. 94-96.

(89j ID., Alto Alentejo, p. 86-87, Est. XXXV-XXXVII.

$\left.{ }^{90}\right) \quad \mathrm{N} .{ }^{\circ} 60$ e três peças semelhantes, mais quatro fragmentos pequenos de bordos não classificáveis.

(91) Outro exemplar, de pasta 1-a, tem diâm. de c. $120 \mathrm{~mm}$ 
52 51-GH-1 Pasta 1-a, com alto teor de cerâmica moída e de mica. Diàm. $260 \mathrm{~mm}$, alt. $99 \mathrm{~mm}$. Est. Vili.

53 54-GH-1 Pasta com abundância de minerais ferro-magnesianos (de origem alentejana?), engobe cor de tijolo (10 YR 4,5/8), grosso e brilhante na parede interior e no exterior do lábio. Diâm. c. $320 \mathrm{~mm}$ ? N. i.

54 57-GH-1 Pasta 1-b. Ranhura funda e torta na parede interior a 16-17 $\mathrm{mm}$ do remate. Diâm. não determinável. Est. Vili.

55 15-GH-24 Pasta 1-d, vestígios de aguada avermelhada? Bordo ligeiramente engrossado no interior. Fabrico tardo-romano (A/C). Diâm. 278 mm. Est. Vili $\left({ }^{92}\right)$.

Cf. Nolen, Alto Alentejo, tipo pratos 6-a, p. 87-88, Est. XXXI, com cronologia sugerida da segunda metade do séc. i até aos inícios do séc. ni ; Alarcão, Valdoca, n. ${ }^{\circ} 2$ da sepultura 26, p. 17-18, Est. Ili, encontrado em conjunto com uma taça de «paredes finas» decorada de fiadas verticais de mamilos, esquema de decoração que nós datámos da época de Nero-Vespasiano (cf. Nolen, Recensão, sobre Mayet, Parois Fines, p. 196); Mezquiriz, Pompado, II, n. ${ }^{\circ}$ 14, 15, p. 115, fig. 62, de Arcedianato, encontrado no estrato II em conjunto com TSH tardia.

Os pratos n.os 51 e 53 com engobe avermelhado fazem também lembrar o fabrico de «pompejanisch-roten Platten» e as suas imitações: cf. Fouilles de Conimbriga, VI, tipo C, n.os 16, 17 e 18, p. 52-55, Est. XII datado, na sua maioria, do séc. i ; Dyson, Cosa, LS 39 e 40, p. 146, fig. 58, dos depósitos 25 D II e 25 B II, dos fins do séc. i até aos inícios do séc. m (p. 139), ambos estes pratos com engobe avermelhado na parede interior. A forma repete-se também na produção de TSC «A» da segunda metade do séc. n e primeira metade do séc. m: HAyes, Late Roman Pottery, forma 181, p. 200-201 , fig. 35.

Pratos semelhantes, todavia de bordo menos reentrante e parede mais aprumada, estão representados por quatro fragmentos

(92) Doze exemplares semelhantes (de pastas do grupo 1 e de 2-b, dos quais dois de fabrico tardo- ou pós-romano, um com aguada alaranjada) têm entre 220 e $280 \mathrm{~mm}$ de diâm., e mais cinco (de pastas do grupo 1) têm 310 a $356 \mathrm{~mm}$ de diâm. 
pequenos: pastas 1-a micácea, 1-b, 3 e uma pasta única com desengordurante de cerâmica moída; têm diâm. entre c. 160 e c. $240 \mathrm{~mm}$. N. i.

Aparentadas com este grupo de pratos e travessas são as:

Travessas de parede recta, bordo reentrante

56 71-HH-25 Pasta 1-a. Diâm. 240 mm. Est. Vili ( $\left.{ }^{93}\right)$.

Cf. Caeiro, Vaiamonte, sepultura 7, n. ${ }^{\circ}$ 4, p. 237-238. Est. LUI; a sepultura 7 foi datada dos finais do séc. i ou do primeiro quartel do séc. $\mathrm{n}$.

\section{Travessas e pratos de bordo boleado, às vezes com ranhuras ou sulcos na parte superior}

57 12-IH-21 Pasta 1-a com elevada presença de cerâmica moída. Diâm. c. $240 \mathrm{~mm}$. Est. IX ( $\left.{ }^{94}\right)$.

Cf. Alarcão, Comum, n. ${ }^{\circ}$ 640, p. 107, Est. XXX, datado séc. v; Santrot, Aquitaine, n. ${ }^{\circ} 45$, p. 60 , com cronologia larga da segunda metade do séc. i de Bordéus, da segunda metade do séc. II da Bretanha e Alemanha, e até ao séc. iv da Alemanha e Alto Garona.

\section{Pratéis de bordo boleado}

58 72-GH-1 Pasta lb/d. Diâm. 132 mm. Ext. IX ( $\left.{ }^{95}\right)$.

Cf. Santrot, Aquitaine, n. ${ }^{\circ} 45$ já citado a propósito do prato n.o 57.

(93) Outro exemplar semelhante (pasta 2-a) tem c. $320 \mathrm{~mm}$ de diâm.

(94) Três exemplares semelhantes (de pastas 1 -a e d) têm 154, c. 260 e 276 mm de diâm.

(95) Outro exemplar semelhante (de pasta 1-b) tem 144 mm de diâm. 
Travessas de parede arqueada, lábio ligeiramente engrossado do lado interior

59 36-HH-25 Pasta 1-a, embora de cor divergente (castanho-claro-avermelhado, 10 YR 5/4). Diâm. c. 320 mm. Est. IX (96).

Cf. Santrot, Aquitaine, n. ${ }^{\circ} 43-a, " p .59$, do período 40-80: este prato tem um acabamento de engobe vermelho pompeiano. Uma cronologia do séc. i e da primeira metade do séc. $\mathrm{n}$ para estas travessas abrangeria, pelo menos, parte do período da sua fabricação; temos, todavia, que tomar em linha de conta que a sua duração pode muito bem ter continuado até uma época mais tardia, já que Gose publica outro prato parecido datável da primeira metade do séc. IV $\left({ }^{97}\right)$.

Pratos e travessas de parede oblíqua, bordo boleado do lado interior

60 2-HI-7 Pasta 1-b. Diâm. c. 200 mm. Est. IX ( $\left.{ }^{98}\right)$.

Cf. Alarcão, Comum, n. ${ }^{\circ}$ 641, p. 107, Est. XXIX, de cerâmica alaranjada fina da época tardo-romana, encontrado em estratos do séc. v; Dyson, Cosa, n. ${ }^{\circ \text { s }}$ LS 33-35, p. 144-145, fig. 57, dos depósitos 25 I, CII e A III respectivamente de fins do séc. i-inícios do séc. ui (p. 139).

\section{Pratos de parede oblíqua, bordo pequeno, bicudo no dorso}

61 11-IH-21 Pasta única em que, dos ingredientes não argilosos, predomina uma abundância de mica de tamanho muito fino, cor cinzenta muito escura (7,5 YR 3/0), parede exterior polida. Diâm. 162 mm. Est. IX (").

Cf. Nolen, Alto Alentejo, tipo pratos 2-b, n. ${ }^{\circ}$ 221, p. 83, Est. XXVIII, da segunda metade do séc. i e do séc. II; ID., Santo André,

(96) Três exemplares semelhantes (de pasta do grupo 1) têm entre 242 e $288 \mathrm{~mm}$ de diâm.

${ }^{(97)}$ Gose, Gefásstypen, n. ${ }^{\circ} 480$, p. 41 , Est. 46, de Trier.

(98) Três exemplares semelhantes (de pastas 1-b e d) têm entre c. 200 e 280 mm de diâm.

(") Outro exemplar semelhante (pasta 1-b) tem diâm. não determinável. 
n. ${ }^{\circ}$ E 5-15, do tipo 2, p. 93, 156, Est. XXXVI, de uma sepultura dos fins do séc. i-inicios do séc. n (p. 133-134); CAEIro, Vaiamonte, n. ${ }^{\circ} 7$ da sepultura 5, p. 235-236, Est. LUI, encontrado com peças de TS dos finais do séc. i ou inícios do séc. n; Alarcão, Comum, n. ${ }^{\circ} 635$ A, p. 93-94 e 106, Est. XXIX, de cerâmica alaranjada fina da época tardo-romana, encontrado em níveis do séc. iv e v. Parece que um prato deste tipo com bordo revirado para o interior, para impedir que o líquido se derramasse, teve uso e procura durante muitos séculos.

\section{Pratos de parede oblíqua, bordo alto e bicudo, virado para o interior}

02 15-IH-21 (Cola com 15-II-1 n. p.) Pasta 1-a com alto teor de cerâmica moída. Diâm. 204, altura 52 mm. Est. IX.

03 53-GH-1 Pasta 1-b, aguada avermelhada fina, na parede interior, reduzido cinzento (pelo uso como frigideira?) no lado exterior. Fabrico tardo-romano (C). N. i. $\left({ }^{\circ}\right)$.

Cf. Nolen, Alto Alentejo, tipo pratos 3-e, especialmente os n. ${ }^{\circ} 249$ e 250 , p. 85, Est. XXIX, com cronologia sugerida da segunda metade do séc. i até o séc. iv; BIGARD, Vaucluse, n. ${ }^{\circ} 74$, dos estratos 00-01, sondagem III, p. 9, fig. IX-I, trata-se de um prato de «terra sigillata cinzenta paleocristã», forma Rigoir 8, encontrado em contexto cronológico dos sécs. $\mathrm{v}$ e vi. Estes paralelos apontam para um longo uso destes pratos de bordo bicudo. No entanto, a preponderância de formas semelhantes encontradas em contextos dos sécs. IV e v, e o fabrico tardo-romano do . $^{\circ} 63$ fazem-nos pensar que a maioria dos exemplares do Alto do Cidreira cabem nos últimos séculos da ocupação romana e talvez mesmo nos inícios do período pós-romano. Esta suposição é reforçada pela cronologia de c. 325$-400 / 420$ da forma Hayes $61 \mathrm{~A}$ de TSC «D» $\left({ }^{101}\right)$ da qual o prato $\mathrm{n} .{ }^{\circ} 63$ com aguada avermelhada pode muito bem ser uma imitação regional tardia.

$\left(1^{\circ}\right)$ Três exemplares semelhantes (de pasta 1-b) tem diâm. entre 204 e c. $270 \mathrm{~mm}$.

(101) H A Y E S, Late Roman Pottery, forma 61 A, p. 100-107, fig. 17-4 e 17-7. 


\section{Prato covo de parede oblíqua, lábio bicudo}

04 7-GH-1 Pasta 1-d de textura branda. Diâm.172mm. Est. IX.

Não podemos menosprezar a possibilidade de o n. ${ }^{\circ} 64$ ser parecido com os n. ${ }^{\text {os }} 289$ e 290 do tipo dos pratos 8-c da tipologia que elaborámos para a cerâmica romana das necrópoles alto-alentejanas. Este tipo faz lembrar a forma de TSH Dragendorff 15/17 tardia dos secs, in e IV (102).

\section{Travessas de parede recta, bordo amendoado e revirado para o interior}

65 5-HH-5 Pasta 1-b. Diâm. 266 mm. Est. IX(103).

Cf. Mezquiriz, Pompado, II, n. ${ }^{\circ}$ 16, p. ill, fig. 56 , de Arcedianato, sector B, estrato III, com cronologia do séc. m; Nolen, Alto Alentejo, tipo pratos 3-a, n. ${ }^{\circ}$ 239, p. 84, Est. XXIX, com diâm. de apenas $156 \mathrm{~mm}$, cronologia sugerida dos fins do séc. i ou do séc. iı ; Alarcão, Comum, n. ${ }^{\circ} 631$, p. 103-106, Est. XXIX, de cerâmica alaranjada fina tardo-romana, encontrada em estratos do séc. V. A carena entre a parede exterior e o bordo de vários exemplares deste tipo repete-se na travessa n. ${ }^{\circ} 13$ da forma Hayes $61 \mathrm{~A}$ em TSC «D» datada entre c. 225 e 400/420 (104).

\section{Travessa do tipo anterior, todavia de bordo mais alongado}

66 13-HH-16 Pasta 1-c micácea. Diâm. c. 340 mm? Est. IX.

Não encontramos paralelos exactos para esta travessa; apenas podemos referir uma peça semelhante : cf. alarcĩo, Comum, n. ${ }^{\circ} 645$,

(102) NoLen, Alto Alentejo, tipo pratos 8-c, p. 89, Est. XXXII.

(103) Três exemplares semelhantes (de pastas 1-a e b/d) têm entre 268 e $320 \mathrm{~mm}$ de diâm. Um deles é de fabrico tardo- ou pós-romano. Dois exemplares (pasta 4-a) com diâm. de c. 300 e $320 \mathrm{~mm}$. têm aspecto de serem de fabrico tardoou pós-romano.

(104) HAYES, Late Roman Pottery, forma 61-A, p. 100-107, fig. 13-3. 
p. 93-94 e 197, Est. XXX, de ceràmica alaranjada fina tardo-romana, encontrada em estratos do séc. $v$.

Travessa de parede aberta e achatada, bordo ein forma de cunha

67 9-FG-24 Pasta 2-a, fabrico tardo-romano (D). Diàm. c. 290 mm. Est. IX.

Esta travessa faz lembrar formas em TSC «D», sem ter, no entanto, paralelo exacto naquele fabrico. As formas 99 e 103 da tipologia de Hayes, do séc. v até ao terceiro quartel do séc. vi serão as mais parecidas $\left({ }^{105}\right)$. Cf. Alarcĩo, Comum, n. ${ }^{\circ} 643$ A, p. 103-107, Est. XXX, de cerâmica alaranjada fina tardo-romana.

Travessa de bordo arrendondado, cavado no dorso

68 3-11-3 Pasta 1-a com elevada presença de cerâmica moída e mica.

Diâm. 346 mm. Est. IX.

Travessa de parede arqueada, bordo engrossado e achatado

69 19-HH-10 Pasta 4-a. Diâm. c. 260 mm. Est. IX.

Não conseguimos encontrar paralelos para as travessas $n .{ }^{\circ} 68$ ou 69; por isso, não podemos sugerir datação para elas. Não queremos, todavia, deixar de as apresentar por serem de formas elegantes, um tanto mais aperfeiçoadas que outras encontras com mais frequência.

\section{BILHAS E JARROS}

As bilhas e jarros para servir água à mesa estão escassamente documentados entre o espólio cerâmico exumado da Villa do Alto do

(106) ID., ibid., forma 99, p. 152-155, fig. 28; vide também: ID., Supplement, p. 516, e Fouilles de Conimbriga, IV, p. 270; forma 103, p. 157-160, fig. 29; Martin, Formes Inédites, forma NV, VI, p. 104, fig. 4-1, dos fins do séc. v até à primeira metade do séc. vi.

Conimbriga, 27 (1988), 61-140 
Cidreira, designadamente se compararmos com a sua abundância, que já anotámos, nas necrópoles do Alto Alentejo (106). A frequência das bilhas é comparável à de Conimbriga; não temos, porém, testemunho idêntico ao grande número de jarros encontrados naquela cidade. Podemos perguntar-nos: qual era a vasilha usada para levar as bebidas à mesa ?

O estado de conservação das bilhas e jarros do Alto do Cidreira é mesmo lamentável, de maneira que nos será impossível ilustrar as formas representadas. Por essa mesma razão também não podemos agrupar as diferentes peças; apenas será possível enumerá-las, anotando as suas características mais salientes.

\section{Bilhas de bocal afunilado}

Nesta categoria estão incluídas as bilhas de gargalo afunilado, embora de bordos muito divergentes.

70 4-HG-23 Pasta 2-a, vestígios de engobe ou aguada acastanhada. Fabrico tardo-romano (C/D). Diâm. 96 mm. Est. IX.

Cf. Mezquiriz, Pompaelo, II, n. ${ }^{\circ} 12$, p. 115, de Arcedianato, sector C, estrato II, dos sécs. iv e v. Será que este suposto «funil»era, de facto, o bocal de uma bilha semelhante ao . $^{\circ} 70$ ?

71 7-HI-7 Pasta 3, aguada ligeiramente mais clara que a pasta (5 YR 6/8).

Diâm. c. 90 mm. Est. IX.

Esta bilha, mais duas de diâm. indeterminável $\left({ }^{107}\right)$, de gargalo quase recto e bordo engrossado, pode ser confrontada com várias do séc. II de Verulamium, ou outra de Cartuja duma cronologia um pouco mais alta $\left({ }^{108}\right)$. Cf. Frere, Verulamium, III, n. ${ }^{\text {os }} 1995,2000$ e 2004, p. 208, fig. 83; Serrano Ramos, Cartuja, n. ${ }^{\circ}$ 93, p. 252, fig. 11.

(106) Nolen, Santo André, p. 74; Id., Alto Alentejo, p. 35.

(107) São estes os n. ${ }^{\text {os }} 60-\mathrm{GH}-1$ de pasta 1 -c e $24-\mathrm{IH}-16$ de pasta 1 -a.

(108) O autor afirma que se trata de uma bilha asada; todavia, o desenho publicado não apresenta qualquer indicação das asas. 
Encontramos fragmentos de três jarros de bocal largo no Alto do Cidreira, um dos quais é de fabrico tardo-romano $\left(109^{*} *\right)$.

As bilhas de bocal constrito e trilobado estão representadas por seis bordos (no), enquanto temos fragmentos de três jarros trilobados $(\mathrm{m})$.

O púcaro/jarro estabelece a ligação entre o grupo dos jarros e os dos potes. Era usado para preparar sopas, servir água ou somente para guardar água na cozinha? $\mathrm{O}$ aspecto queimado da peça $\mathrm{n} .{ }^{\circ} 72$ faz pensar que ia ao lume, pelo menos para aquecer água, e talvez com sopas ou outros alimentos líquidos.

\section{Jarro asado, de colo aprumado e alto}

72 30-IH-16 Pastai. Diâm. do bordo 114 mm. Est. IX.

É mais provável que este jarro estivesse munido com uma só asa; é de fabrico tardo-romano (112). Cf. alarcão, Comum, vários púcaros de grés do Baixo Império, por exemplo n. ${ }^{\text {os }} 822,827,830$, 837,842 , p. $112-113$ e 119-120, Est. XLII-XLIII.

\section{POTES E URNAS}

Outra forma de cerâmica «comum», muito frequente entre o espólio do Alto do Cidreira, é o pote. No entanto, geralmente apenas nos restam pequenos fragmentos dos bordos, bojos e fundos. Consequentemente, somos mais uma vez obrigados a apresentar um conjunto de vasos aparentados, mas com grande variedade na forma, sem podermos assinalar uma possível evolução cronológica nem apontar eventuais contactos comerciais.

(109) São os n.os 28-HH-25, pasta 1-a, diâm. $116 \mathrm{~mm}$; 59-GH-1, pasta 1-b/d, diâm. $122 \mathrm{~mm}$; 29-HH-25, pasta 1-a, com vestígios de aguada ou engobe fino avermelhado, n. i.

(no) De pasta 1-b: os n.os 8-sup-82, 98-HH-25, este último de fabrico tardo- ou pós-romano com superfície negra; de pasta 1-a: os n. ${ }^{\circ}$ 105-HH-25 e 24-GH-1 ; de pasta 1-b/d: o n. ${ }^{\circ} 8-\mathrm{IH}-21 / \mathrm{II}-1$, e de pasta 4 -a o n. ${ }^{\circ}$ 5-HH-22.

(m) De pasta 1-a: o n. ${ }^{\circ} 9-\mathrm{II}-1$; de pasta 1-c: o n. ${ }^{\circ} 8-\mathrm{HH}-3$; e de pasta 1-d: o n. ${ }^{\circ} 17-\mathrm{HG}-25$.

(112) Existem mais quatro exemplares semelhantes (de pastas 1-a e 4-a e b), e o n. ${ }^{\circ} 20-1 \mathrm{H}-21$ de uma pasta com abundantes minerais ferro-magnesianos (veja o capítulo sobre as pastas, p. 33). 
Potes de bordo em forma de aba soerguida e gargalo baixo

78 1O-IH-21 Pasta 1-a com alto teor de cerâmica moída e mica. Parede exterior brunida. Diâm. 110 mm. Est. X.

74 70-GH-1 Pasta 2-b. Diâm. 180 mm. Est.X.

75 61-GH-1 Pasta 1-a com muita cerâmica moída. Fabrico tardo-romano (A). Diâm. 198 mm. Est. X (113).

Cf. Gose, Gefâsstypen, n. ${ }^{\circ}$ 530, p. 45, Est. 53, de Oberaden da época augustana; Alarcão, Comum, n. ${ }^{\circ}$ 403, p. 81, 83, Est. XIX, de cerâmica calcitica do Alto Império, encontrado em camadas flávias. Estes dois paralelos apontam para uma cronologia alta, o que está em contradição com o n. ${ }^{\circ} 75$ de cerâmica tardo-romana.

\section{Pote de bordo em forma de aba soerguida}

76 30-GH-1 Pasta 1-b. Diâm. 132 mm. Est.X.

\section{Potes de bordo recto e eyasado}

77 20-IH-16 Pasta 4-a. Diâm. c. 140 mm. Est.X.

78 27-GH-1 Pasta 1-d. Diâm. c. 120 mm. N. i.

79 21-HH-25 Pasta 1-b, aguada avermelhada, negra na parede exterior.

Fabrico tardo-romano (A). Diâm. 154 mm. Est. X (114).

$\mathrm{O}$ aspecto mais característico deste potes são as ranhuras finas existentes tanto no dorso como na sobarba do bordo. Todavia, não pensamos que se trate de uma decoração intencional, mas sim de uma falta de alisamento por parte do oleiro. Podíamos citar paralelos de todas as épocas para esta forma corrente e simples.

Aparentado com os potes de bordo recto e evasado é um vaso grande com uma moldura saliente no ombro :

(113) Nove exemplares semelhantes (de pastas 1-a e b, 2-a e b, 4-a) têm diâm. entre 110 e $192 \mathrm{~mm}$.

(114) Quatro exemplares semelhantes (de pastas do grupo 1 e 4-a) têm diâm.entre 156 e $178 \mathrm{~mm}$ (um dos quais também de superfície negra, de fabrico tardo- ou pós-romano). 
80 32-HH-10 Pasta 1-b. Diàm. c. 200 mm. Est. X.

Cf. Santrot, Aquitaine, n. ${ }^{\circ} 236-\mathrm{a}$, p. 130, com decoração incisa ao pente; de Gironde, dos meados do séc. i até aos inícios do séc. in; de Paris, dos meados do séc. n. Frere, Verulamium, III, n. ${ }^{\text {ss }} 255-257$, p. 214 , fig. 85 , do séc. $n$.

\section{Potes de bordo contracurvado, com ressalto no colo}

81 9-Sup-81 Pasta 1-b micàcea. Diàm. 126 mm. Est. X (115).

O ressalto encontra-se em muitos dos potes, tanto do Alto corno do Baixo Império, publicados por Alarcão. Cf. Alarcão, Comum, muitos dos potes de cerâmica calcícita do Alto Império: n. ${ }^{\text {os }} 403$ A, 403 B, 403 C, 408 A, 409, p. 81-83, Est. XIX; ou outros, de grés, do Baixo Império: n. ${ }^{\text {os }} 885,885$ A, p. 112-113, Est. XLVIII.

\section{Potes de bordo pequeno, contracurvado}

82 23-IH-16 Pasta 1-b. Diâm. 158 mm. Est. XI (116).

Potes de bordo engrossado e aberto

Cinco fragmentos de bordos desta forma $\left({ }^{117}\right)$ podiam ser assim classificados; a exiguidade dos casos não permite, porém, que se desenhe um perfil fidedigno.

\section{Potes de bordo pequeno, dobrado para o exterior}

83 21-IH-21 Pasta 1-a. Diâm. c. 160 mm. Est. XI (118).

Cf. Santrot, Aquitaine, n. $^{\circ} 316$, p. 148, de Bordéus, do período 40-80, e da Gália, Alemanha, Suíça e Espanha, do princípio do séc. i

(115) Dois exemplares semelhantes (de pastas 1-b) têm respectivamente diâm. de $149 \mathrm{~mm}$ e indeterminável.

(116) Dez exemplares semelhantes (de pastas do grupo 1) têm entre c. $110 \mathrm{e}$ c. $180 \mathrm{~mm}$ de diâm., dois dos quais (64-GH-1 e ll-HG-25) de fabrico tardo- ou pós-romano, o último com aguada avermelhada na parede interior.

(117) São os seguintes n.os: 11-HH-10, 83-HH-25, 4-HG-22, 21-IH-12. e 19-IH-17.

(118) Seis exemplares semelhantes (de pastas do grupo 1 e 4-a) têm diâm. entre 136 e $240 \mathrm{~mm}$ (um deles é de fabrico tardo- ou pós-romano). 
até ao séc. ii; Stuart, Gewoon Aardewerk, n. ${ }^{\circ} 292$ do tipo 201 A, p. 71-72, Est. 19, que o autor confronta com o n. ${ }^{\circ} 530$ da tipologia de Gose; Stuart anota a sua presença em camadas de 15/12-12/8 a. C. em Oberaden, e até ao ano 539, em Trier.

Potes de bordo pequeno, amendoado, revirado para o exterior e cavado ou com sulco na parte superior

84 13-IH-13 Pasta 1-a. Forma tardo-romana? Diám. 176 mm. Est. XI $\left({ }^{119}\right)$.

\section{Pote com bordo curto, em forma de aba horizontal}

85 62-HH-25 Pasta 1-a, vestígios de decoração pintada de bandas horizontais de 10 a $50 \mathrm{~mm}$ de largura, agora de cor cinzenta. Diâm. $204 \mathrm{~mm}$. Est. XI.

A decoração e a cozedura deste pote fazem-nos pensar que seja de fabrico tardo- ou pós-romano $\left({ }^{120}\right)$.

\section{Potes com bordo engrossado em forma de aba curta}

86 2-HH-10 Pasta 1-c com elevada presença de cerâmica moída. Diâm. c. $140 \mathrm{~mm}$. Ext. XI.

87 3-HH-15 Pasta 1-c, aguada avermelhada, reduzida para cinzento no bordo, fabrico tardo-romano (A). Diâm. c. 176 mm. Est. XI ( $\left.{ }^{121}\right)$.

\section{Potes de bordo amendoado e oblíquo}

88 19-IH-21 Pasta 1-b. Diâm. c. 170 mm. Est. XI (122).

Cf. Serrano Ramos, Cartuja, n. ${ }^{\circ} 43$, p. 248, 257, fig. 7 , dos fins do séc. i até meados do séc. $n$.

(119) Cinco exemplares semelhantes (de pastas 1-a e b, 1-b e 4-a) têm diâm. entre 150 e c. $180 \mathrm{~mm}$, dos quais dois também de fabrico tardo- ou pós-romano.

$\left({ }^{12 \circ}\right)$ Outros potes (pasta $\left.1-\mathrm{a} \mathrm{e} \mathrm{b}, 4-\mathrm{a}\right)$ de formas semelhantes à do n. ${ }^{\circ} 85$, mas sem decoração pintada, têm entre 148 e $174 \mathrm{~mm}$ de diâm. (quatro peças das quais 4-a e 1-b, de fabrico tardo- ou pós-romano).

(121) Oito exemplares semelhantes (de pastas do grupo 1, 2-b e 4-a) têm diâm. entre 142 e c. $180 \mathrm{~mm}$ (dois dos quais de fabrico tardo- ou pós-romano).

i122) Doze exemplares semelhantes (de pastas do grupo 1 e 2-b) têm entre 138 e 192 mm de diâm. (dois ou mais de fabrico tardo- ou pós-romano). 
Potes de colo aprumado, pasta cinzenta fina micácea, superfície alisada

Cf. Alarcão, Comum, n. ${ }^{\circ}$ 877, p. 123, Est. XLVII, de camadas do séc. y e de destruição; Mezquiriz, Pompado, II, n. ${ }^{\circ}$ 22, fig. 50, p. 106, de Arcedianato, sector A, estrato II, dos sécs. iv e v.

Aparentado com os potes anteriores é o seguinte de fabrico tardo-romano, mais grosseiro.

90 5-HH-8 Pasta 1-a com muita cerâmica moída. Superfície negra, alisada, baça. Fabrico tardo-romano (B). Este pote podia ter sido asado (cf. n. ${ }^{\circ}$ 72). Diâm. reconstituído c. 133 mm. Est. XI.

\section{Potes de bordo pequeno, aprumado}

91 79-HH-25 Pasta 1-b. Diâm. 122 mm. Est. XII (124).

Cf. Alarcão, Comum, n. ${ }^{\circ} 403$ A, p. 81 e 83, Est. XIX, de cerâmica calcítica do Alto Império, encontrado nos canos flávios e trajânicos das termas; Mezquiriz, Pompeio, II, n. ${ }^{\circ}$ 22, fig. 58, p. 112, de Arcedianato, sector $\mathrm{B}$, estrato IV, dos fins do séc. i-inicios do séc. II, N. ${ }^{\circ}$ 92, p. 207, fig. 118, de Plaza de San José, estrato IV, do séc. i, todavia encontrado em conjunto com moedas tardo-romanas.

Os seguintes potes são todos de fabrico tardo- ou pós-romano. Não é só a pasta dura, geralmente muito grosseira, que indica a cronologia tardia, também os perfis dos bordos, muitas vezes com ranhuras e molduras finas, e as paredes relativamente delgadas são características da produção do período de transição dos fins da época romana para os primeiros séculos medievais.

(123) Dois exemplares semelhantes da mesma pasta têm 68 e $90 \mathrm{~mm}$ de diâm.

(124) Seis exemplares semelhantes (de pastas 1-a, 2-b e 4-a) têm entre 98 e $160 \mathrm{~mm}$ de diâm. (dois, de pasta 4-a, são de fabrico tardo- ou pós-romano). 
Potes de bordo pequeno, revirado para o exterior e cavado na sobarba

92 7-HH-3 Pasta 1-a com muita cerâmica moída. Fabrico tardo-romano (A). Diâm. 142 mm. Est. XII.

93 24-HG-24 Pasta única com desengordurante constituído por cerâmica branca moída (veja o texto $n .^{\circ} 19$ ), superfície negra. Fabrico tardo ou pós-romano (B). Diâm. 74 mm. Est. XII (125).

Cf. Henzel, Condorcet, G 38-3, p. 346, Est. XVIII-13; Mezquiriz, Pompado, II, n. ${ }^{\circ} 83$, fig. 109, de Plaza de San José, estrato III, uma camada remexida dos séc. II-IV (p. 196 e 202).

Pote de parede em forma de «S», bordo cavado do dorso

94 10-HG-23 Pasta 2-a, superfície negra. Fabrico tardo ou pós-romano (B/D). Diâm. 230 mm. Est. XII.

Pote de bordo amendoado, biselado no exterior

e ligeirattiente envasado

95 4-HH-3 Pasta 1-b, vestígios de engobe fino, avermelhado do lado interior do bordo, reduzido e, por isso, cinzento na parede exterior. Fabrico tardoou pós-romano (C). Diâm. c. $136 \mathrm{~mm}$. Est. XII.

Pote de bordo amendoado e bicudo, decorado com ranhuras Anas salientes

96 71-GH-1 Pasta 1-c, vesígios de aguada negra. Fabrico tardo ou pós-romano (B). Diâm. 118 mm. Est. XII.

Pote pequeno de bordo soerguido e ombro decorado com ranhuras finas salientes

97 25-GH-1 Pasta 1-c, superfície negra. Fabrico tardo ou pós-romano (B). Diâm. c. 120 mm. Est. XII ( $\left.{ }^{126}\right)$.

(125) Três exemplares semelhantes (de pastas 1-a, 2-b, um deles com superfície negra) têm 128, 180 ou $98 \mathrm{~mm}$ de diâm. respectivamente.

( $\left.{ }^{126}\right)$ Outro exemplar semelhante (pasta 4-a), tem um diâm. não determinável.

Conimbriga, 27 (1988), 61-140 
Cf. Alarcão, Comum, n. ${ }^{\circ}$ 887, p. 123, Est. XLVIII, encontrado em níveis do séc. v; Henzel, Condorcet, G 44-14, p. 346, Est. XIX-2. Do mesmo tipo genérico, sem ser bem igual ao n. ${ }^{\circ} 97$, podemos citar: Bogard, Vaucluse, sondaze III, couche 08-11, p. 8, fig. VIII-16, dos séc. v e vi.

Pote pequeno de gola envasada e lábio engrossado, decoração de ranhuras finas salientes

98 5-HH-10 Pasta 1-a, superfície negra. Fabrico tardo- ou pós-romano (A). Diâm. c. 100 mm. Est. XII.

Potes de gola envasada

99 3-HH-2 Pasta 1-b. Diâm. 68 mm. Est. XII (127).

Cf. Mezquiriz, Pompaelo, II, n. ${ }^{\circ}$ 23, p. 120, fig. 69, de Arcedianato, sector D-E, estrato II, dos sécs. iv e v.

Relacionadas com os potes são as urnas que frequentemente tomam a forma de potes grandes. A escavação do Alto do Cidreira apenas nos deu fragmentos de uma urna asada e dois bordos de urnas ou potes grandes. Estes últimos têm perfis comparáveis:

\section{Urna ou talha pequena com bordo engrossado}

e virado para o exterior

100 23-HH-25 Pasta 1-a. Diâm. 305 mm. Est. XII ( $\left.{ }^{128}\right)$.

Urna com duas asas, colo aprumado

101 7-IH-21 Pasta 1-b. Diâm. 160 mm. Est. XII.

É de estranhar que não encontremos paralelo para esta urna na bibliografia ao nosso alcance.

(127) Outro exemplar semelhante de uma pasta única, bem depurada, tem c. $80 \mathrm{~mm}$ de diâm.

${ }^{128}$ ) Outro exeplmar semelhante de fabrico tardo- ou pós-romano (pasta 2-b), tem diâm. de c. $300 \mathrm{~mm}$. 


\section{CANTAROS E DÓLIOS}

Da grande quantidade de cântaros de fabricos tardios encontrados no Alto do Cidreira podemos deduzir que a localização num alto determinou a necessidade de ir buscar a água necessária para a vida quotidiana, ao menos na época tardo- ou pós-romana. À excepção do n. $^{\circ} \mathbf{1 0 2}$ podemos dividir os cântaros em dois grupos, nitidamente distintos em função da forma e da pasta. $O$ primeiro inclui as ânforas e as ânforas/cântaros da época romana que serão apresentadas por G. Cardoso em posterior publicação $\left({ }^{129}\right)$. $\mathrm{O}$ segundo grupo, da idade tardo- ou pós-romana, mostra mais variedade no contorno do bocal, embora também constitua conjuntos homogéneos devido às pastas utilizadas.

\section{Cântaro de colo alto, cilíndrico, lábio arredondado}

102 16-IH-12 Pasta 1-b/d micácea. Decoração de grupos de linhas verticais brunidas. Conserva-se apenas o arranque de uma asa (provavelmente a única). Diâm. c. 110 mm. Est. XIII.

Não encontramos paralelo para este cântaro da época romana.

Os seguintes cântaros são integralmente de fabrico tardo ou pós-romano, muitos deles de uma pasta feldspática, cozida a temperatura elevada, e de parede relativamente delgada. $\mathrm{Na}$ campanha de 1987, na villa romana do Monte de Cegonha (concelho de Vidigueira), peças (ainda inéditas) muito semelhantes aos n. ${ }^{\text {ss }} 103$ e 104, foram encontradas numa lixeira com cerâmica vidrada, tipo «corda seca» do séc. xn. Estes são munidos com duas asas de fita largas que arrancam do gargalo e assentam na parte mais larga da pança.

Cântaros de colo alto, bordo engrossado e cavado na sobarba

103 5-HG-23 Pasta 2-a. Fabrico tardo- ou pós-romano (D). Diâm. 156 mm. Est. XIII $\left({ }^{130}\right)$.

(129) As ânforas e ânforas/cântaros serão incluídas no re'atório final dos trabalhos arqueológicos efectuados nesta Villa.

$\left(1^{\circ}\right)$ Outro exemplar semelhante (pasta 2-b) tem $150 \mathrm{~mm}$ de diâm. 
Cf. Neuru, Carthage, n. ${ }^{\circ}$ 36, p. 202, Est. VI, uma ânfora do tipo «Spatheion» de um depòsito do séc. v. A forma tem antecedentes no

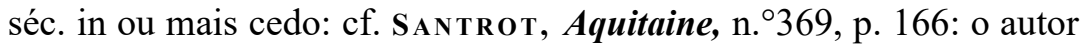
cita um exemplar da segunda metade do séc. i, outros dois dos fins do séc. " ou do séc. $m$.

\section{Cântaros de colo alto, evasado, bordo amendoado} ou arredondado

104 33-IH-16 Pasta 2-a, alisamento ou aguada fina, reduzida para cinzento na parede exterior. Fabrico pós-romano (D). Diâm. $182 \mathrm{~mm}$. Est. XIII (131).

Cf. Alarcão, Comum, n. ${ }^{\circ} 856$ B, p. 121, Est. XLV, do «grés» tardo-romano, encontrado em estratos dos sécs. IY e v; BAZZANA, Santa Fé, n. ${ }^{\circ}$ 5, p. 177, fig. 1, da Idade Média.

Cântaros de colo alto, evasado, bordo arqueado para o exterior

105 29-IH-16 Pasta 2-a, aguada acastanhada. Fabrico pós-romano (D). Diâm. 174 mm. Est. XIII (132).

Cf. Alarcão, Comum, n. ${ }^{\circ} 856$ A, p. 121, Est. XLV, do «grés» tardo-romano, encontrado em camadas do séc. $\mathrm{v}$, e em níveis de destruição do período suevo-visigótico.

Os cântaros apresentados a seguir, torneados num barro não feldspático, ao contrário do que aconteceu com as peças anteriores, também datam da época tardo- ou pós-romana. Por motivo da pasta utilizada, e também devido à diferença da forma e ao tamanho reduzido, pensamos que devem estar ligados a um ambiente comercial diferente.

(m) Três exemplares semelhantes (n.os 12 e 13-IH-17, 2-II-16), embora de bordo arredondado, todos da pasta 2-a, têm entre c. 120 e $180 \mathrm{~mm}$ de diâm. ; dois deles mostram uma superfície negra.

(132) Outro exemplar de perfil igual (pasta 2-a, superfície negra) tem c. $200 \mathrm{~mm}$ de diâm., embora um terceiro (pasta 1-a), com bordo biselado, tenha diâm. mais pequeno, de $152 \mathrm{~mm}$. 
Cântaros de gargalo alto, aìunilado, bordo virado para o exterior

106 73-GH-1 Pasta 1-b, superfície negra. Fabrico tardo- ou pós-romano (B). Diàm. 86 mm. Est. XIII.

107 26-HH-25 Pasta 1-b, superficie negra. Fabrico tardo- ou pós-romano (B). Diàm. 112 mm. Est. XIII (133).

Os dólios do Alto do Cidreira agrupam-se em dois tipos: o primeiro, de bordo contracurvado e da pasta feldspàtica (pasta 2); o outro, com bordo dobrado sobre o ombro e de pastas 1-a ou 4-a. Esta divisão possivelmente tem origem na sua cronologia: os primeiros encontram paralelos no séc. i e em estratos remexidos do séc. V em Conimbriga; quanto aos últimos, podemos confrontá-los com peças do séc. $\mathrm{v}$ ou de datação um pouco duvidosa entre c. 50 e 150 .

\section{Dólios de bordo revirado para o exterior, pasta feldspàtica}

108 45-GH-1 Pasta 2-a. Diâm. indeterminável. Est. XIV.

109 1-HG-19 Pasta 2-a. Arranque de asa com uma dedada preservada num fragmento do bojo. Grafito «D» no ombro. Diâm. c. $310 \mathrm{~mm}$. Est. XIV (134).

110 92-HH-25 Pasta 2-a. Diâm. c. 368 mm. Est. XIV.

Cf. Alarcão, Comum, n. ${ }^{o s}$ 293-310, p. 71-73, Est. XIV-XV : são talhas semelhantes aos nossos n. ${ }^{\circ} 108$ e 109, de pasta originária de Pombal-Barracão, encontradas em camadas augustano-trajânicas; n. ${ }^{\circ} 326$, p. 77 , Est. XV pode ser confrontado com o dòlio n. ${ }^{\circ} 110 \mathrm{e}$ n. ${ }^{\text {os }} 702,710$ (este último especialmente parecido com o n. ${ }^{\circ} \mathbf{1 0 9}$ ), p. 110-112, Est. XXXIV: são três talhas de cerâmica alaranjada quartzítica, de cerâmica calcítica, e de cerâmica alaranjada grosseira respectivamente; as três de camadas do séc. v, mas de destruição e, por isso, de cronologia incerta (cf. Fouilles de Conimbriga, I, p. 178-179).

(133) Outros exemplares semelhantes (de pastas 1-b e c) têm diâm. entre 88 e $125 \mathrm{~mm}$.

(134) Outra peça de pasta 2-a, com bordo de rolo, tem diâm. de $368 \mathrm{~mm}$. 


\section{Dólios de bordo dobrado sobre o ombro}

111 6-HH-9 Pastal-a. Diâm. do interior do bordo 264 mm. Est. XIV (135)

Cf. Alarcão, Comum, n. ${ }^{\circ}$ 709, p. 112, Est. XXXIV, de cerâmica alaranjada grosseira, encontrado em depósitos de destruição do séc. v; n. ${ }^{\circ}$ 928, p. 127, Est. LII, de cerâmica calcítica com ilite, do período tardo-romano, também encontrado num depósito de destruição do séc. v; VEGAs, Común, tipo 49, n. ${ }^{\circ}$ 6, p. 118, fig. 42, de Tarragona, do séc. $v$.

Restos de sete exemplares desta forma foram achados fora de estratigrafía, perto de Enchurrasqueira, no vale do rio Sado $\left({ }^{136}\right)$. Estes fornos parecem, contudo, ter funcionado entre meados do séc. i e o séc. iv $\left({ }^{137}\right)$.

\section{PESOS}

\section{PESOS DE TEAR}

Na publicação dos pesos de tear do Alto do Cidreira seguimos a tipologia estabelecida para os pesos de Conimbriga por A. M. Alarcão e F. Mayet $\left({ }^{138}\right)$.

Ao contrário do que acontece em Conimbriga e noutras estações, por exemplo Tiro de Cañón (139), a presente colecção está dividida quase igualmente entre os pesos de forma rectangular e de forma piramidal (três da primeira e quatro peças da segunda categoria, mais um exemplar de forma indeterminável), enquanto esta última forma era a preferida em Conimbriga. Todavia, um grupo como o presente de, apenas, oito exemplares é pequeno demais

(135) Um exemplar semelhante (pasta 4-a) tem diâm. no interior do bordo de $274 \mathrm{~mm}$, enquanto um terceiro (pasta 1-a) é de diâm. indeterminável.

(136) Diogo et olii, Enchurrasqueira, 1984, n. ${ }^{\text {os }} 27-33$, p. 11-12, Est. III.

${ }^{(137)}$ ID., ibid., p. 6.

(138) Fouilles de Conimbriga, VII, p. 55-57.

(139) Ibid., p. 60, fig. 2; BenAVEnTE, Tiro de Cañón, p. 123-132, onde entre os pesos de forma documentada podemos contar 22 exemplares trapezoides ou troncopiramidais, contra apenas dois rectangulares. 
para dai se deduzirem conclusões tipológicas. Um ou dois orifícios não parece ter qualquer significado cronológico em Conimbriga nem entre as colecções de pesos do Vale do Ebro publicadas. Baseado nestes conjuntos, Benavente concluiu que a preferência por pesos de um só ou dois orifícios deve ser exactamente isso, uma preferência tradicional de vizinhança $\left({ }^{140}\right)$. É de notar que entre os pesos do Alto do Cidreira figuram seis de uma e apenas um de duas aberturas, e que este último é o exemplar que também se destaca do conjunto quanto ao seu peso. Também temos que chamar a atenção para o peso n. $^{\circ} 3$ do tipo invulgar II: é dum só orifício, enquanto em Conimbriga os cinco exemplares desta configuração todos são perfurados com duas aberturas. Os nossos exemplares com altura completa preservada têm $105\left(n .^{\circ} 1\right)$ e $97\left(n .^{\circ} 5\right) \mathrm{mm}$ de altura, o que concorda com os achados de Conimbriga que, na sua maioria, medem entre 85 e $110 \mathrm{~mm}\left({ }^{141}\right)$. Quanto ao peso das peças, o das de tamanho médio (grupo B) situa-se à volta de 395-400 gramas em Conimbriga ( ${ }^{142}$ ), enquanto que, dos quatro pesos inteiros do Alto do Cidreira, três $\left(n .^{\text {os }} 1,3,5\right)$ têm entre 328 e 334 gramas e apenas um (n. ${ }^{\circ} 4$, a que falta um fragmento, e por isso, parte do seu peso) atinge 527 gramas. Aqui está nitidamente representado o tear de dois tipos de fios, mas não necessariamente dois teares diferentes.

Concordamos com as autoras da publicação dos pesos de tear provenientes de Conimbriga quanto à sua observação de que todas as peças com grafitos semelhantes necessariamente devem datar da mesma época restrita $\left({ }^{143}\right)$. Não concordamos, porém, inteiramente com a sugestão de que apenas a forma I poderia ter durado além da época de Trajano $\left({ }^{144}\right)$, enquanto todas as outras são do período cláudio- ou flávio-trajânico. Pode ser um fenómeno ilusório, talvez devido à estratigrafía mais bem preservada daquela época. Quatro dos nossos pesos (n. ${ }^{\text {os }} 1,2$, 4, e mais um exemplar fragmentado não inventariado) foram moldados em pastas feldspáticas parecidas com a pasta de tipo 2, usada na sua maioria para tornear os dólios e

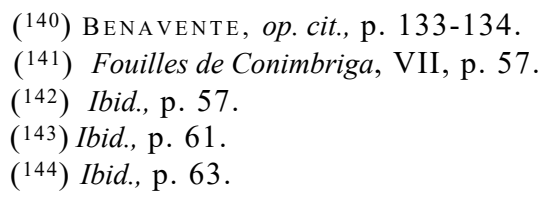


cântaros da época tardia (infra p. 35). Será isso uma indicação de fabrico igualmente tardio destes pesos das formas I, III e VI ? Sem dúvida que também se tecia durante o Baixo Império e no período tardo ou pós-romano.

\section{Forma I (paralelepípedo de secção rectangular)}

1 1-HG-18 Um orifício. Pasta 2-a, laranja (Munsell 2,5 YR 6/8), sulco à volta do orifício. Alt. $105 \mathrm{~mm}$, larg. $53-50 \mathrm{~mm}$, espes. $35 \mathrm{~mm}$, peso 330 gr. Levemente gasto na parte inferior, indicando que foi usado na fila superior do tear. Est. XV.

2 26-HH-5 Um orifício. Pasta 4-a, laranja escuro (Munsell 2,5 YR 4,8) Fragmento da parte superior. Larg. $49 \mathrm{~mm}$, espes. $32 \mathrm{~mm}$. N. i.

Esta é a forma mais numerosa em Conimbriga e ali datada a partir dos Flávios por um período ainda mal definido $\left({ }^{145}\right)$.

\section{Forma II (Paralelepípedo de secção quadrada)}

3 1l-HH-3 Um orifício. Pasta 2-b, laranja (Munsell 2,5 YR 5/8) - cinzento acastanhado. Alt. $104 \mathrm{~mm}$, larg. $53 \mathrm{~mm}$, espes. $43 \mathrm{~mm}$, peso 328 gr. Uma marca em forma de cruz. Est. XV.

Esta marca também está assinalada em sete pesos de Conimbriga, seis exemplares da forma VI, um dos quais dum estrato claudiano, os outros de camadas de destruição do séc. v ( $\left.{ }^{146}\right)$.

\section{Forma VI (Frente trapezoide, rectangular de lado)}

4 1-HG-23 Dois orificios. Pasta 2-a, cinzento escuro avermelhado (Munsell 5 YR 4/2) para castanho avermelhado (2,5 YR 4/4). Alt. 100 $\mathrm{mm}$, Jarg. 68-73 mm, espes. $49 \mathrm{~mm}$. Falta um fragmento da base, peso preservado 515 gr. Est. XV.

5 2-HG-23 Um orifício. Pasta 4-a, laranja (Munsell 5,5/8). Alt. $101 \mathrm{~mm}$, larg. 63-64 mm, espes. $33 \mathrm{~mm}$, peso 334 gr. Est. XV.

(145) Ibid., p. 63. Existe ainda um fragmento da parte superior dum peso desta forma com um só orifício.

(146) Ibid., n. ${ }^{\text {os }} 237,5$ da forma III, p. 72, Est. XV, duma camada flávia; 256,1, p. 74 , Est. LXIV-2.

Conimbriga, 27 (1988), 61-140 
6 8-IH-16 Um orifício. Pasta 4-a, vermelho/laranja acastanhado (Munsel 10 R 5/6 - 5 YR 6/6). Fragmento da parte superior, larg. ao nível do orificio $50 \mathrm{~mm}$, espes. $33 \mathrm{~mm}$. Grafito de duas linhas paralelas correndo em diagonal. N. i.

Em Gonimbriga esta forma está datada do periodo flàvio-trajànico $\left({ }^{147}\right)$.

7 Sup-81. Fragmento da parte inferior dum peso pequeno de forma desconhecida. Pasta 1-a, laranja (Munsell 2,5 YR 5,5/8). Grafito preservado em que possivelmente se pode $1 \mathrm{er}$ um M. N. i.

Será isso a marca $\mathrm{M}$ de M/aelonis], da oficina que forneceu tantos pesos a Conimbriga durante o período Cláudio-Flávios ? ${ }^{(148)}$.

\section{PESOS CIRCULARES}

Geralmente os pesos circulares são considerados pesos de rede da pesca. Não há qualquer indicação que desminta este uso para os dois exemplares do Alto do Cidreira: a abertura central é larga e gasta. No entanto, será melhor, no futuro, ter consciência de que esta finalidade ainda não está perfeitamente documentada, e procurar indicações de outros usos que estes pesos (também) possam ter tido. $\mathrm{O}$ facto de um exemplar quase igual ter sido encontrado em Torre de Palma ( ${ }^{149}$ ) e outro semelhante em Conimbriga, duas estações bem longe do mar ou de rios significativos, é, para nós, indícios de que nem sempre terão servido para fundar a rede de pesca.

8 18-IH-16 Pasta 3, laranja amarelado (Munsell 5 YR 7/8). Dimensão máx. $84 \mathrm{~mm}$, espes. $27 \mathrm{~mm}$. Parece ser cortado duma maneira muito rude dum imbrex. Est. XV.

(147) Ibid., p. 64. Existe ainda um peso desta forma, incompleta e muito fragmentada, de um único orifício.

(148) Fouilles de Conimbriga, II, p. 184-186.

(149) Trata-se de uma peça inédita do Museu Nacional de Arqueologia e Etnologia, n. ${ }^{\circ}$ de inventário 10001.5900.82. 
9 19-IH-16 Pasta única, com cerâmica moída, mica e grânulos de óxido de ferro, laranja acastanhado (Munsell 5 YR 6/6). Falta quase metade da peça, espes. $19 \mathrm{~mm}$. Parece ter sido cortado do fundo dum pote. Est. XV.

Cf. Fouilles de Conimbriga, VII, n. ${ }^{\circ} 380$, p. 202, 203, Est. LVI; Silva, Alcácer do Sal, n. ${ }^{\circ} 223$, p. 188, fig. 18 dum nível da Idade do Ferro.

\section{BIBLIOGRAFIA}

Alarcão (A. M.) e Martins (A. N.), Cerámica aparentada com «Paredes Finas» de Mérida, «Conimbriga», XV, 1976, p. 91-109. (= Alarcão, PF de Mérida).

Alarcão (A. M.) e Ponte (S. da), As lucernas romanas do Paço Ducal de Vila Viçosa, «Conimbriga», XV, 1976, p. 73-91. (= Ala RCão, Lucernas romanas).

Ala RCão (J. de), Sepultura Luso-romana descoberta no concelho de Constância, «Museu», 2. ${ }^{\text {a }}$ série, n. ${ }^{\circ}$ 10, 1966, p. 5-12. ( = Alarcão, Constância).

-----, A Necrópole de Monte Farrobo (Aljustrel), «Conimbriga», XIII, 1974, p. 5-32. (一 Ala RC Ão, Farrobo).

-----, Cerâmica comum local e regional de Conimbriga, Coimbra, 1974. (= AlarCão, Comum).

------, Vidros do Castelo de Alcácer do Sal, «Setúbal Arqueológica», IV, 1978, p. 155-170. (= Alarcão, Alcácer do Sal).

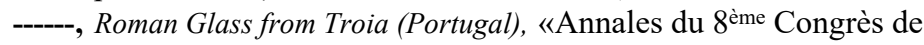
l'Association Internationale pour l'Histoire du Verre» (Londres-Liverpool, 18-25 Septembre, 1979), Liège, 1981. (= AlarCão, Troia).

AlarCão (J. de) e (A. M.), Vidros romanos de Conimbriga, Conimbriga, 1965 ( = Alarcão, Vidros de Conimbriga).

-----, O espólio da necrópole de Valdoca (Aljustrel), «Conimbriga», V, 1966, p. 7-104. ( - AlarCão, Valdoca).

Alarcão (J. de) e Étienne (R.), Fouilles de Conimbriga, I, "L'Architecture», Paris, 1977. (= Fouilles de Conimbriga, I).

Alarcão (J. de) et olii, Fouilles de Conimbriga, VI, Céramiques Diverses et Verres, Paris, 1976. (= Fouilles de Conimbriga, VI).

— , Fouilles de Conimbriga, VII, Trouvailles Diverses et Conclusions Générales, Paris, 1979. (= Fouilles de Conimbriga, VII).

Almeida (e. A. Ferreira de), Escavações no Monte Mozinho (1974), Penafiel, 1974. (= Almeida, Monte Mozinho).

A propos des Céramiques de Conimbriga, «Conimbriga», XIV, 1975, p. 5-224. 
Azuar Ruiz (R.), Excavaciones en el recinto fortificado arabe denominado «Castillo del Rio» (Aspe-Alicante), Campaña 1979, «Noticiario Arqueológico Hispanico, 15, 1983, p. 299-340. (= Azuar Ruiz, Castillo del Rio).

bazzana (A.) e Climet (S.), El yacimiento medieval de Santa Fé de Clivia (Valencia), «Noticiario Arqueológico Hispanico», 18, 1984, p. 257-339. (= Bazzana, Santa Fé).

Bе́mont (С.) е Јасов (J.-P.), ed. La terre sigillée gallo-romaine, Lieux de production $d u$ haut Empire; implantations, produits, relations, Paris, 1986. (= B B́ MonT, Terre sigillée gallo-romaine).

Benavente (J.), Juste (N.), Perales (M.a), Picazo (J.) e Sancho (A.), Tiro de Cañón, Fusayolas y pondera, «Kalathos», vol. 5-6, 1985-86, p. 118-137. (= Benavente, Tiro de Cañón).

Berger (L.), Römischer Glässer aus Vindonissa, (Veröffentlichungen der Gesellschaft pro Vindonissa, IV), Basileia, 1960. (= BERGER, Vindonissa).

B Liquez (L. J.), Greek and Roman Medicine, «Archaeology», 34-2, 1891, p. 11-17.

Borgard (P.), Le Village de la Colline du Chateau à Fontaine de Vaucluse (Vaucluse), Un site de U Antiquité Tardive (V-VI'eme Siècle), «Bulletin

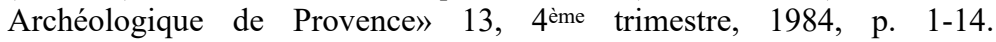
(= BORGARD, Vaucluse).

Branco (D. Antonio de Castello), ferreira (O. da Veiga) e Cardoso (G. Pereira), Descoberta de uma mini-máscara de «terra cota» na estação lusitano-romana do Alto da Cidreira (Cascais), em «Estudos Italianos em Portugal», n. ${ }^{\text {os }}$ 33-34-35, 1970-1971-1972, p. 99-104. ( = Branco, Mini-máscara.

Budischovsky (Marie-Christine), Le thème du nègre dans VAdriatique à Vépoque romaine «Hommages à Maarten J. Vermaseren», vol. I, Leiden, 1978, p. 191-207. (= BuDISCHOVSKY, Le thème du nègre).

Caeiro (J. O. da Silva), O espólio da Herdade do Reguengo, Vaiamonte, AP, série III, VII-IX, 1974-1977, p. 227-241. (= CAEIro, Vaiamonte).

-----, A sepultura $n .^{\circ} 3$ da necrópole da Herdade do Reguengo (Vaiamonte), «Setúbal Arqueológica», IV, 1987, p. 203-210. (= CAEIro, Vaiamonte sep. 3).

-----, O espolio arqueológico da Herdade do Reguengo (Vaiamonte), «Conimbriga», XVIII, 1979, p. 115-121. (= CAEIRo, Espolio arqueológico).

Charlesworth (C.), The Glass, em Frere (S.), Verulamium Excavations I, (Reports of the Research Committee of the Society of Antiquaries of London, 28) Oxford, 1972, p. 196-215. ( = CHARLESWORTH, Verulamium I).

— , The Glass, em Frere (S.), Verulamium Excavations, III, (Oxford University Committee for Archaeology, Monograph N. ${ }^{\circ}$ I). (= Ch A RLESWORTH, Verulamium, III).

-----, The Glass, em Ne AL (D. S.), The excavation of the Roman villa in Gadebridge Park, Hemel Hempstead, 1963-8, (Reports of the Research Committee of the Society of Antiquaries of London, n. ${ }^{\circ}$ XXXI, London, 1974, p. 203-207. (= CHARLESWORTH, Hemel Hempstead). 
Delgado (H.), mayet (F.) e Alargão (A. Moutinho), Fouilles de Conimbriga, IV, Les Sigillées, Paris, 1975 (= Fouilles de Conimbriga, IV).

Deneauve (J.), Lampes de Carthage, Paris, 1969. (= Deneauve, Carthage).

Dio go (A. M. Dias), Fornos de Anforas do Monte de Enchurrasqueira e do Vale da Cepa - Notícia preliminar, «Conimbriga», XXII, 1983, p. 211-215. ( = Diogo, Enchurrasqueira e Cepa).

Diogo (A. M. Dias) et alli, O material dos fornos romanos da Enchurrasqueira no Museu do Mar, Cascais, Série Arqueológica, 1, Cascais, 1984. ( = Diogo, Enchurrasqueira).

Dyson (S. L.), Cosa, The utilitarian pottery, Memoirs of the American Academy in Rome, XXXIII, Rome, 1976. (= Dyson, Cosa).

Etienne (R.), Fabré (G.) e Leveque (P. e M.), Fouilles de Conimbriga, II, Épigraphie et Sculpture, Paris, 1976. (= Fouilles de Conimbriga, II).

F RE ME R S O R F (F.), Das Naturfarbene sogenannte Blaugrüne Glass in Köln, Colonia, 1958. (= Fr EMER s Dor F, Blaugrüne Glas).

Frere (S.), Verulamium Excavations I, (Reports of the Research Committee of the Society of Antiquaries of London, 28), Oxford, 1972. (= Frere, Verulamium I).

----- , Verulamium 111, London, 1985. (= Frere, Verulamium 111).

Gose (E.), Gefässtypen römischen Keramik im Rheinland (Bonner Jahrbuch, 1), Kevelaer, 1950. (= GosE, Gefässtypen).

Harden (D. B.), The Glass, em hawkes (C. F. C.) e Hull (M. R.), Camulodunum, First report on the excavations at Colchester, 1930-1939, Oxford, 1947, p. 287-307. (= HARDEN, Camulodunum).

----- , Recensão sobre W E L K E R (E.), Nida-Heddernheim, em «Antiquaries Journal», LVIII, part I, p. 189-190. (= HARDEN, Becensão).

Hayes (J. W.), Late Boman Pottery, London, 1972. (= Hayes, Late Boman Potery).

-----, Supplement to Late Boman Potery, London, 1980. ( = Hayes, Supplement).

-----, Boman and Pre-Boman Glass in the Boyal Ontario Museum, Toronto, 1975. ( = HAY ES, Ontario Glass).

Hense (W.) et alli, La Céramique Médiéval de Condorcet, Contribution à F étude d'un village deserté des Baronnies [Drôme), «Archéologie Médiéval», V, 1975, p. 307-369. ( = HeNsel, Condorcet).

Isings (G.), Boman glass from dated finds, (Archaelogica Traiectina, II), Groningen, 1957. (= Ising s, Dated finds).

Lancel (S.), Verrerie antique de Tipasa, Paris, 1967. (= Lancel, Tipasa).

Lıтн (S. M. E. Van), Komischen Glas aus Valkenburg, Z. H., em «Oudheidkundige Mededelingen uit het Rijksmuseum van oudheden te Leiden», LIX-LX, 1978-1979. (= Liт H, Valkenburg).

-----, Glas aus Asciburgium, em «Rheinische Ausgrabungen», 23, Beiträge zur Archäologie des römischen Rheinlands, IV, 1983, p. 211-281. (= Lıтн, Asciburgium).

Maia (M. G. Pereira), «Sigillata» (Paleocristã) cinzenta de Tróia de Setúbal, «Setúbal Arqueológica», II-III, 1976-1977, p. 411-418. (= MaIA, Tróia). 
MAY Eт (F.), Les céramiques à parois fines dans la Péninsule Ibérique, Paris, 1975. (= Mayet, Parois fines).

------, Les Céramiques Sigillées Hispaniques, contribution à Vhistoire économique de la Péninsule Ibérique sous VEmpire Romain, Paris, 1984. (= MAYet, Sigillées Hispaniques).

Menzel (H.), Antiken Lampen im Römisch-Germanischen Zentralmuseum zu Mainz, Mainz, 1969. (= Menzel, Lampen).

Mesquiriz (M. A. de Catalán), Terra Sigillata Hispanica, I e II, Valência, 1961. (= MEZquiriz, Hispanica).

---- Pompaelo, II, (Excavaciones en Navarra, IX), Pamplona, 1978. (= MezQUiriz, Pompaelo, II).

Neuru(L.) et alii, Late Roman Pottery; a fifth century deposit from Carthage, «Antiquités Africaines», 16,1980, p. 195-211. (= NEuru, Carthage).

Nolen (J. U. Smit), Recensão sobre MAYet, Parois fines ${ }_{i}$ «Conimbriga», XV, 1976, p. 189-197. (Nolen, Recensão).

-----, Cerâmica comum de necrópoles do Alto Alentejo, Lisboa, 1985. (= Nolen, Alto Alentejo).

Nolen (J. U. Smit) et Dias (L. F.), A necrópole de St. ${ }^{\circ}$ André, parte II, Os materiais, «Conimbriga», XX, 1981, p. 33-178. (= Nolen, Santo André).

Oswald (F.), The Terra Sigillata (Samian Ware) of Margidunum, Nottingham, 1948, (= Oswald, Margidunum).

Perichon (R.), et alii, Céramiques Domestiques Gauloises et Gallo-Romaines du Nord Est du Massif Central. Essai de Typologie, "Archéologie», 6, St. Étienne, 1977. (= PÉrICIION, Céramiques domestiques).

Pereira (M. ${ }^{\mathrm{a}}$ A. Horta), O Dolium Cineràrio com Skyphos vidrado a verde da Necrópole de Paredes (Alenquer), «Conimbriga», IX, 1970, p. 45-74. (= Pereira, Paredes).

Ponte (S. da), Instrumentos de Fiação, Tecelagem e Costura de Conimbriga, «Conimbriga», XVIII, 1978, p. 134-146. (= Ponte, Fiação).

Rigoir (J.), La Céramique Paléochrétienne Sigillée Grise, «Provence Historique», X, 1960, p. 1-91. (= Rigoir, Sigillées grise).

------, les Sigillées Paléochrétiennes Grises et Orangées, «Gallia», XXVI, 1968, Fase. 1, p. 177-244. (= RigolR, Grises et Orangées).

Rigoir (J. e Y.), Les dérivées des sigillées paléochrétiennes en Espagne, RSL, XXXVII, 1972, p. 33-68. (- Rigoir, Les dérivées).

Rocha (S.), Estações pré-romanas da Idade do Ferro nas vizinhanças da Figueira, Coimbra, 1971. (= Rосна, Figueira).

Santrot (M.-H. e J.), Cerámiques Communes Gallo-Romaines d'Aquitaine, Paris, 1979. (= SANTrot, Aquitaine).

Serrano Ramos (E.), Cerámica Común del Alfar de Cartuja (Granada), «Baetica» (Estudios de Arte, Geografìa e Historia), I, Málaga, 1978, p. 243-271. (= Serrano Ramos, Cartuja).

Silva (C. Tavares da) et alii, Escavações arqueológicas no Castelo de Alcácer do Sal (Campanha de 1979), «Setúbal Arqueológica», VI-VII, 1980-81, p. 149-218. (= Silva, Alcácer do Sal). 
S TUA R T (P.), Gewoon Aardewerk uit de Romeinse Legerplaats en de bijbehorende Grafvelden te Nijmegen, (Beschrijving van de verzameling in het Rijksmuseum G. M. Kam te Nijmegen, VI), Leiden, 1977. ( = S Tu A R T, Gewoon Aardewerk).

------, Een Romeins graf veld uit de eerste eeuw te Nijmegen. Onversierde terra sigillate en gewoon aardewerk, (Beschrijving van de verzameling in het Rijksmuseum G. M. Kam te Nijmegen), Leiden, 1977. (= STUART, Romeins Graf veld).

T. S. H. Terra Sigillata Hispánica, Monografías del Museo Arqueológico Nacional, 2, 1983, «Boletín del Museo Arqueológico Nacional», Madrid, 1, 2,1983. (= T. H.S.).

Vegas (M.), Cerámica común romana del Mediterráneo Occidental, (Publicaciones eventuales, 22), Barcelona, 1973. (= VEgas, Común).

Vess b e r g (O.), The Swedish Expedition, vol. IV, part 3, The Hellenistic and Roman periods in Cyprus, Stockholm, 1956. (= Vess B ERG, Cyprus).

Welker (E.), Die römischen Gläser von Nida-Heddernheim, (Schriften des Frankfurter Museums för Vor- und Frühgeschichte, III), Frankfurt am Main, 1974. (= WELKER, Nida-Hedernheim). 

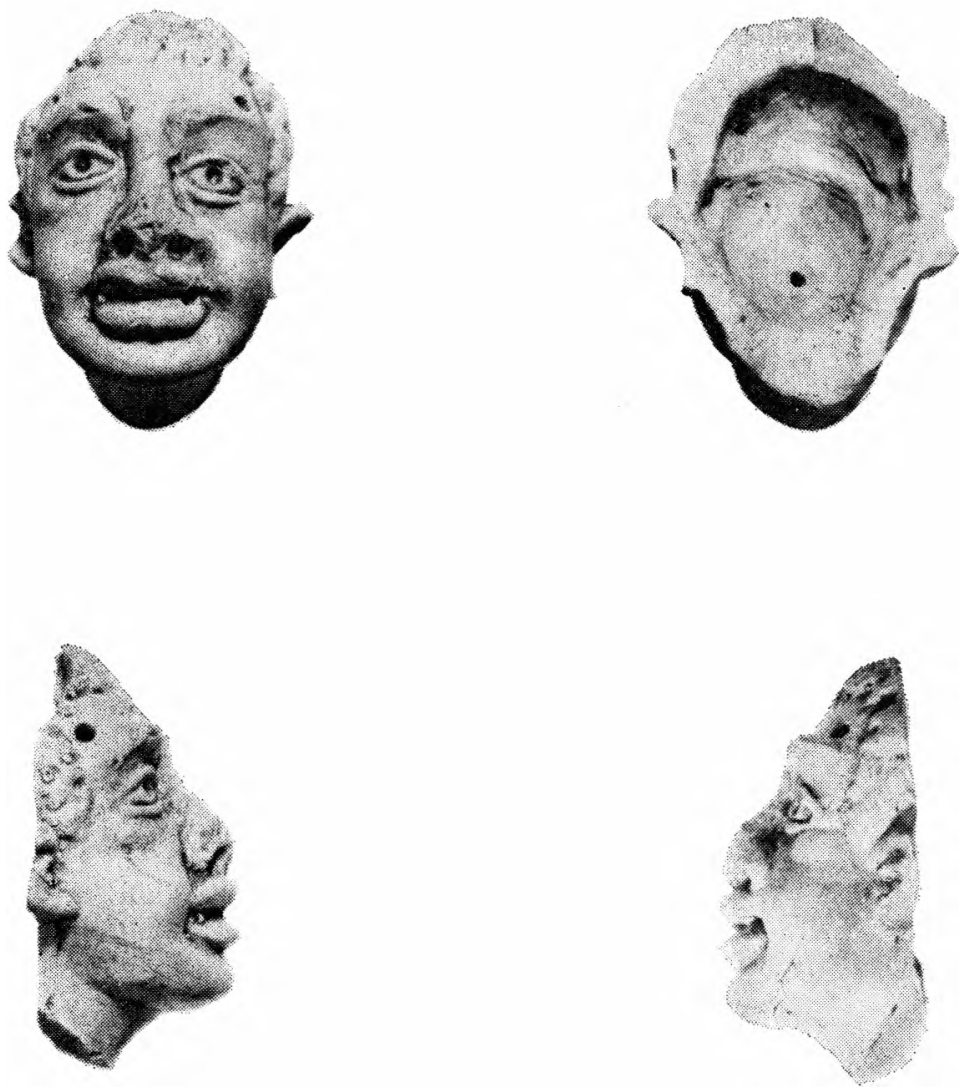

F IG. 1-Minimáscara do negro 
Est. I
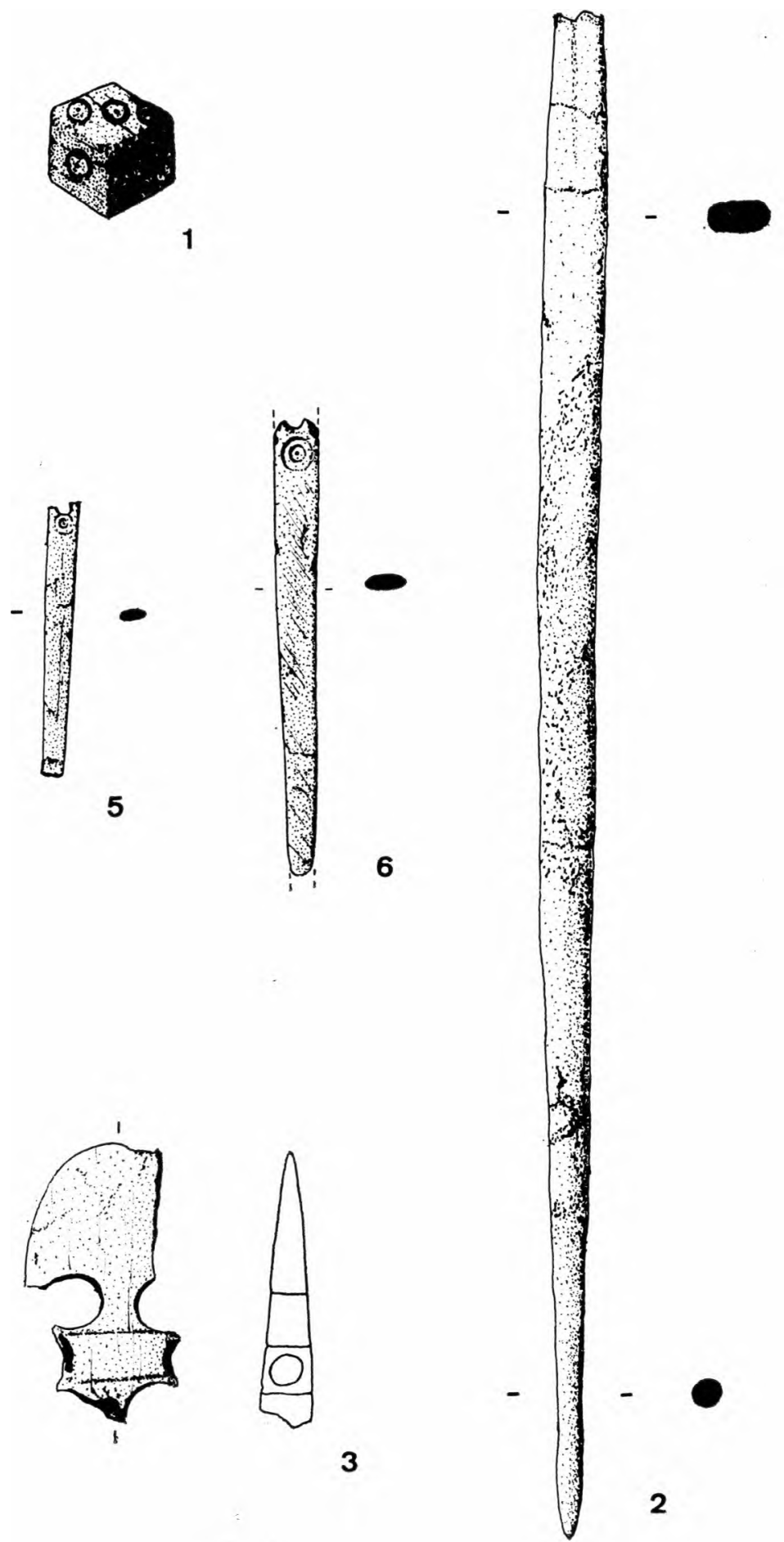

3

Objectos de osso n.os 1-6

Esc. 1: 1 
Est. IT

1

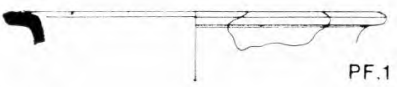

PF.1

SS.1
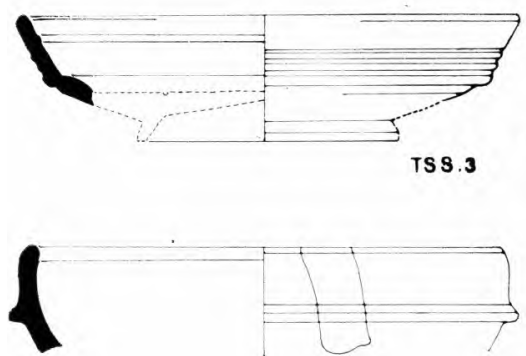

1
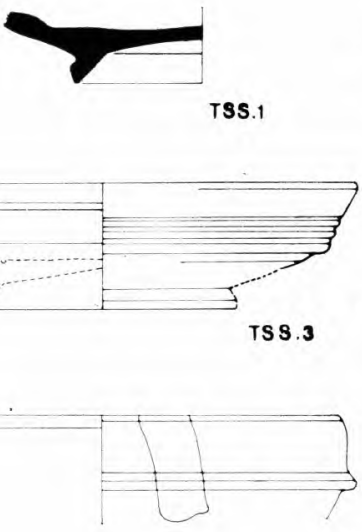
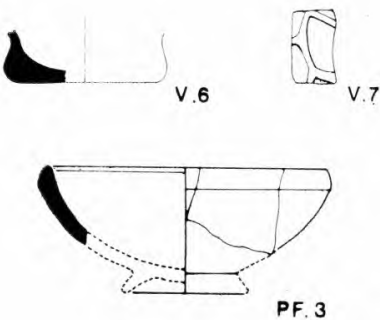

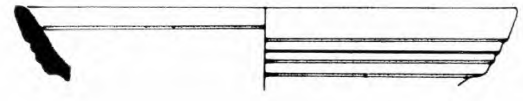

TSS. 2

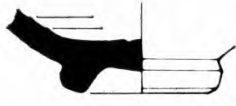

TSH.4
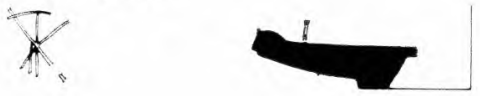

TSH.6

T SH. 5
TS 3.3

TSS. 5

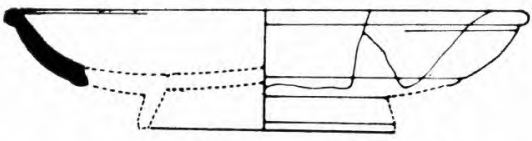

T S S . 4

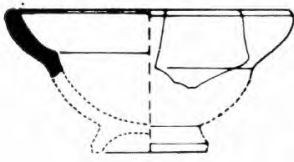

TSH.1
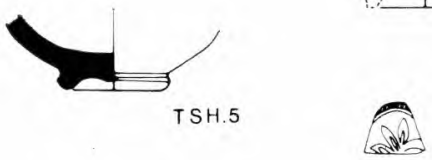

TSH. 7

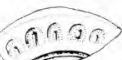

TSH.10

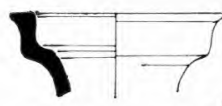

CB.1

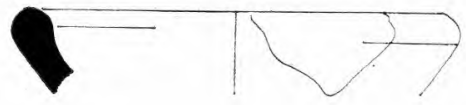

CB.7

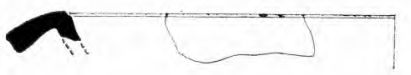

CB. 2

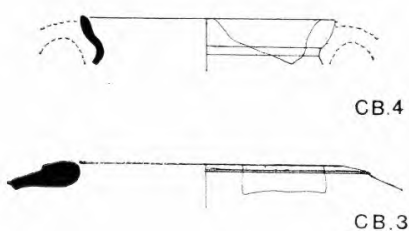

Vidro (V) n.os 1, 3, 6 e 7 ; «paredes finas» (PF) n.os 1 e 3; Terra Sigillata sudgálica (TSS) n.osl-5; Terra Sigillata Hispânica (TSH) n.os 1, 4-7 e 10; lucerna (L) n. ${ }^{\circ} 1$; Cerâmica Branca (CB) n. ${ }^{\text {ss }} 1-4$ e 7 Esc. 1:3 
Est. III
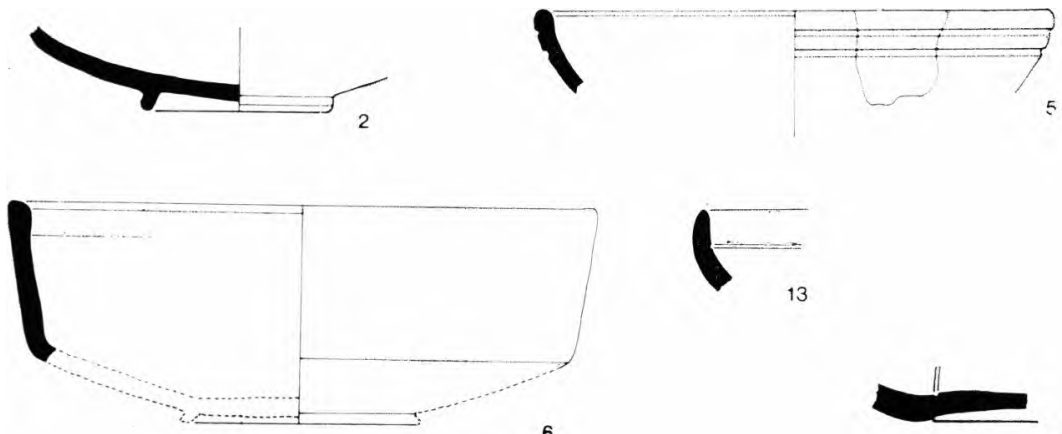

13
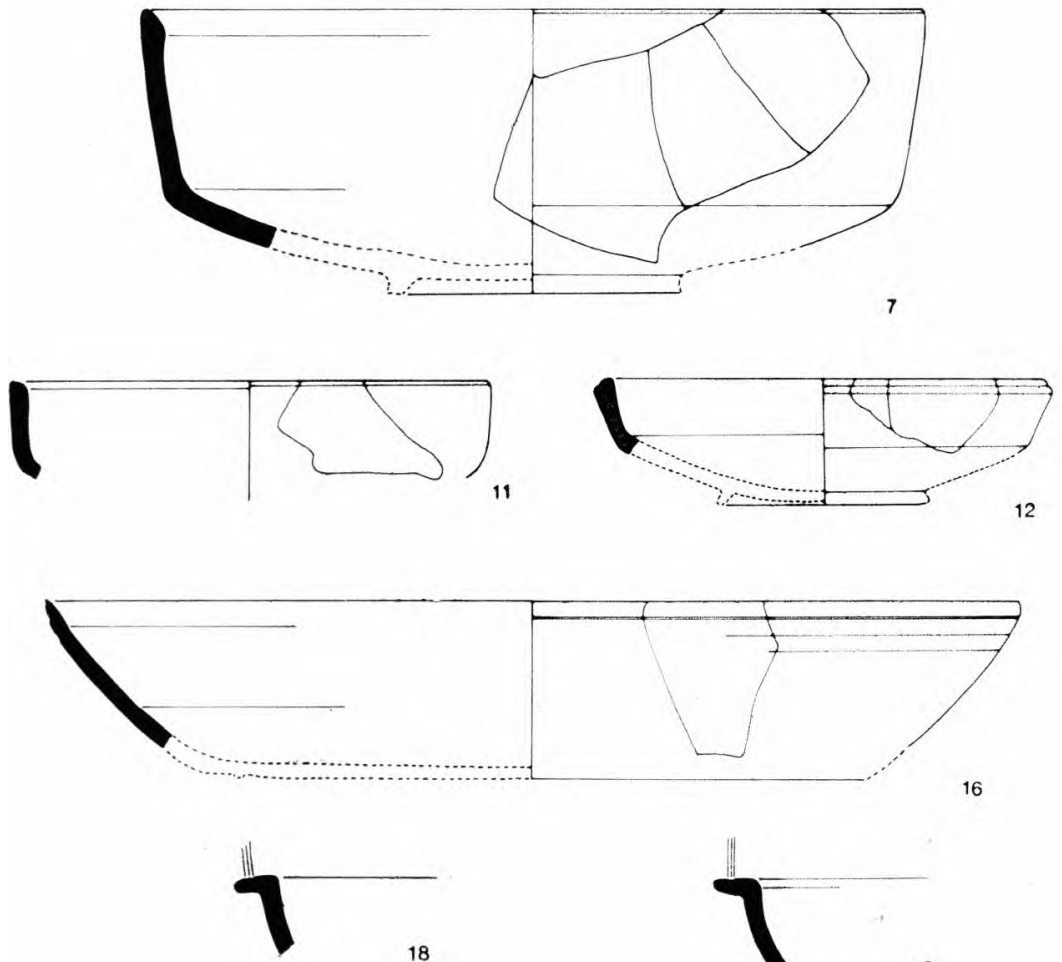

16

18

19

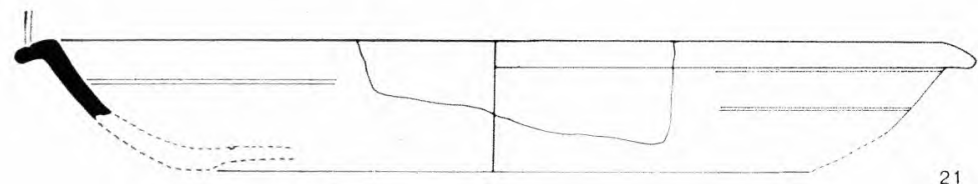

Terra Sigillata Clara n.os 2-21

Esc. 1: 3 
Est. IV
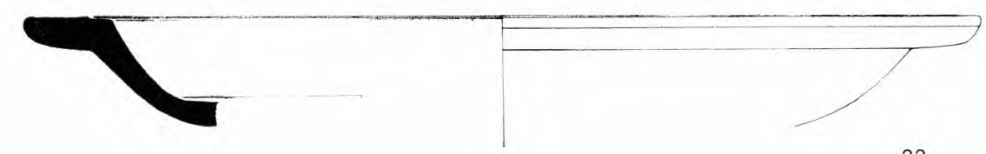

22
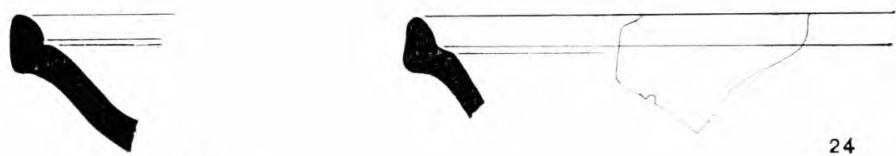

24

23
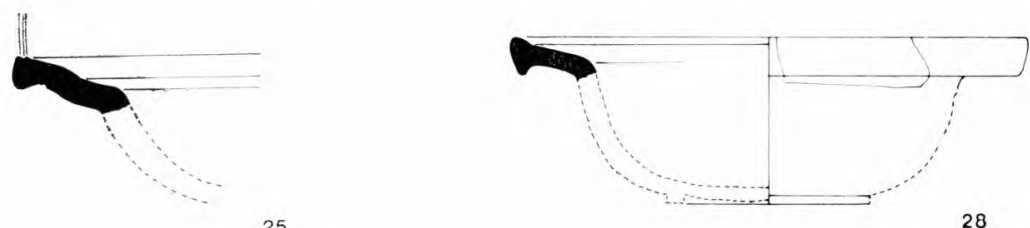

25

28

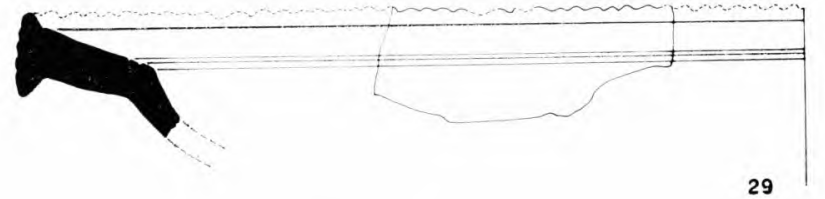

29
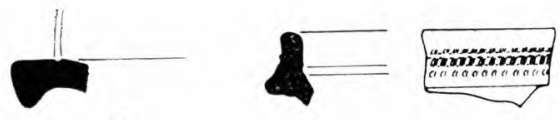

36

26
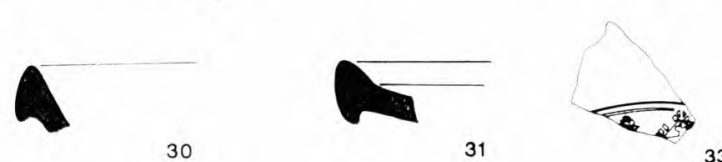

30

31

33

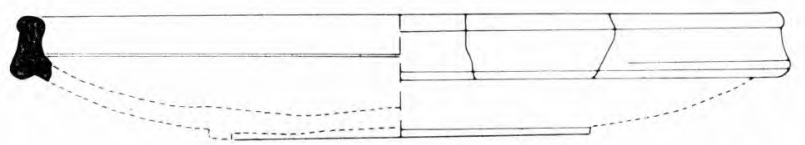

34
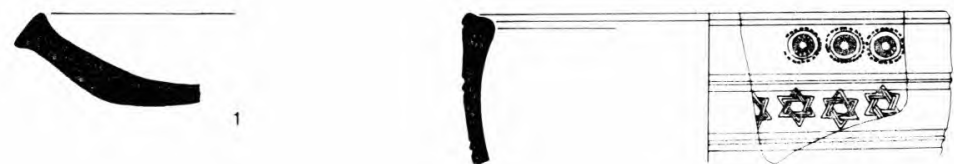

Terra Sigillata Clara n. ${ }^{\text {os }}$ 22-26; Sigillata Cinzenta Paleocristã n. ${ }^{\text {os }} 1$ e 2

Esc. 1: 3 
Est. V
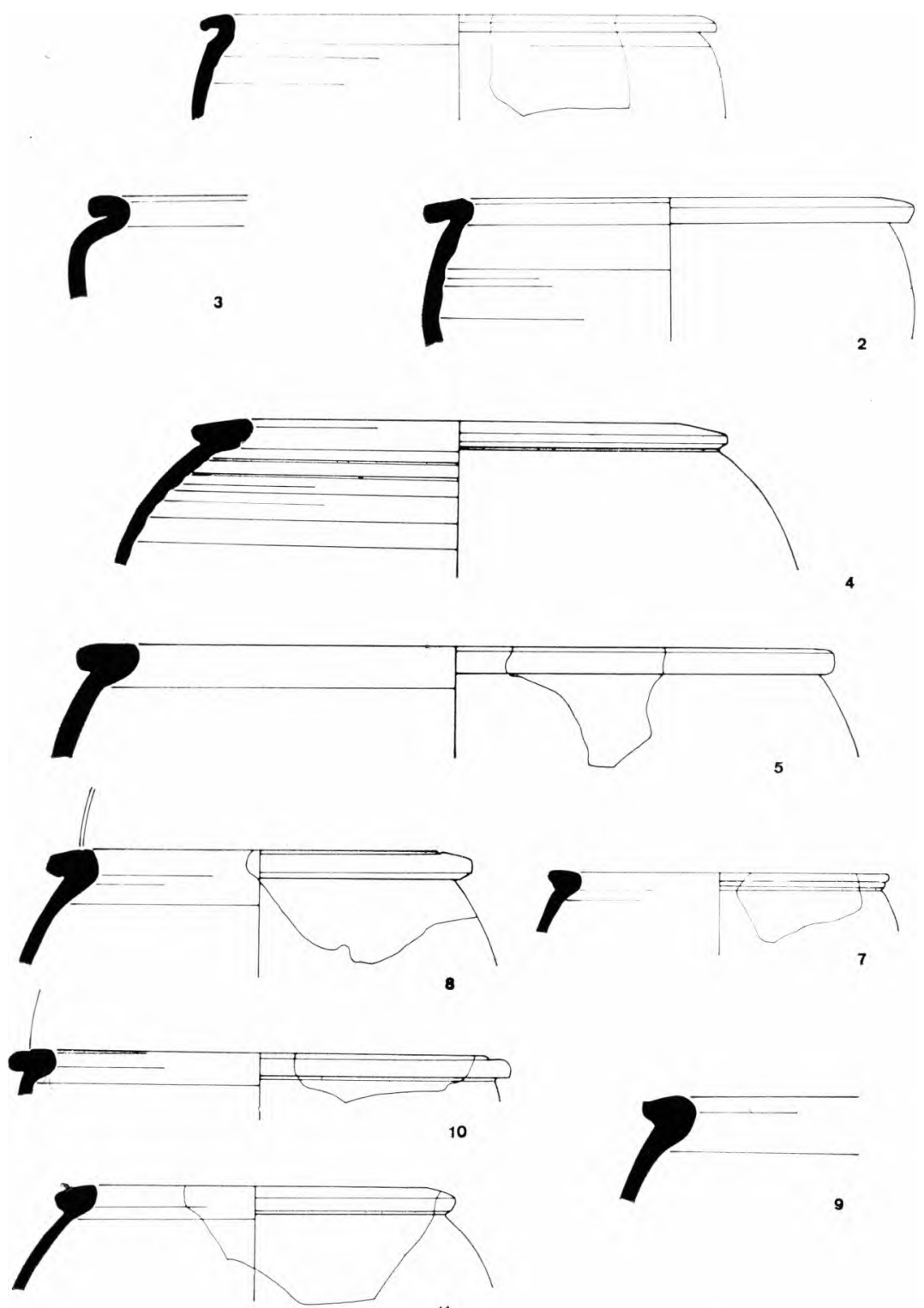

11

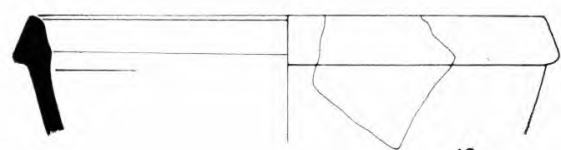

12

Cerâmica comum; panelas n. ${ }^{\text {os }} 1-12$

Esc. 1: 3 
Est. VI
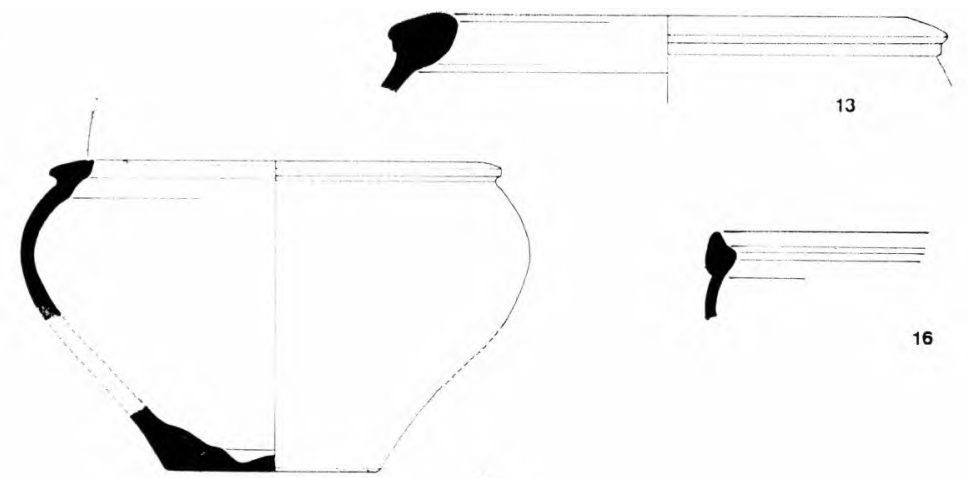

15
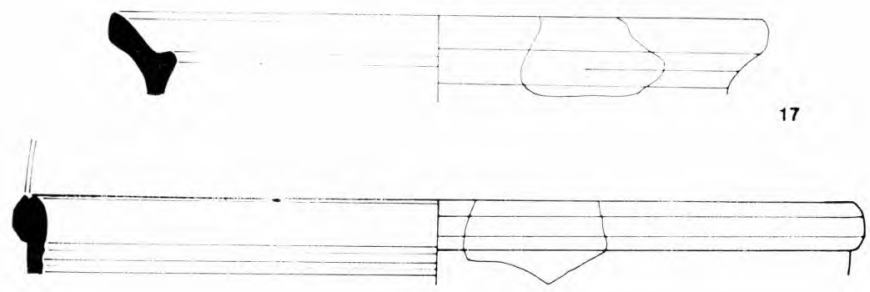

18
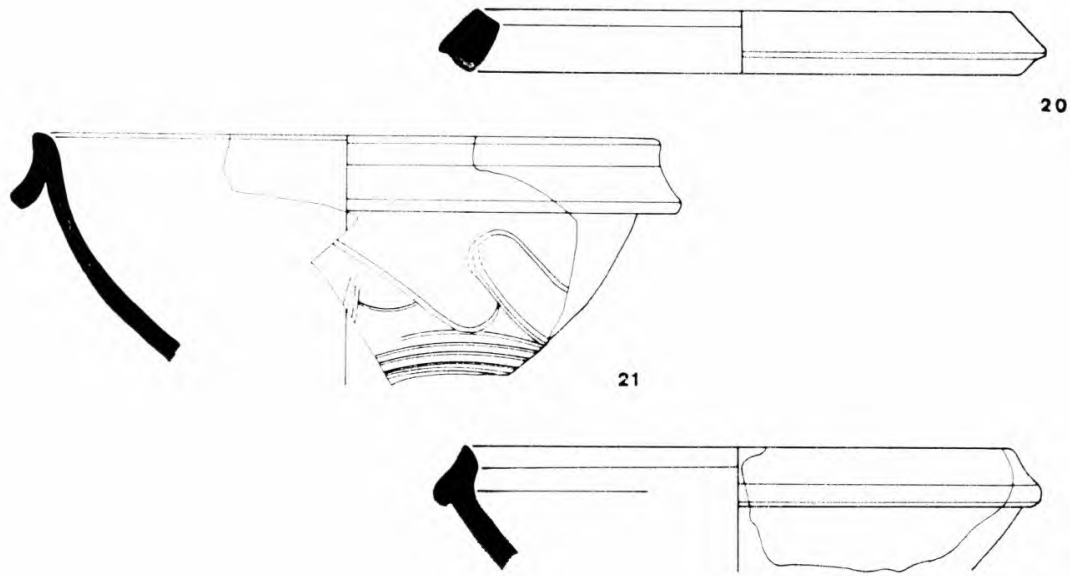

22

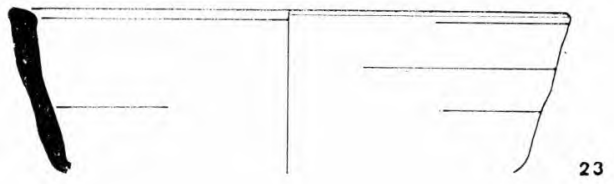

Cerâmica comum: panelas n. ${ }^{\text {os }} 13-18$; suporte n. ${ }^{\circ} 20$; terrinas n. ${ }^{\circ s} 21$ e 22 ; tigela n. $^{\circ} 23$

Esc. 1:3 
Est. VII
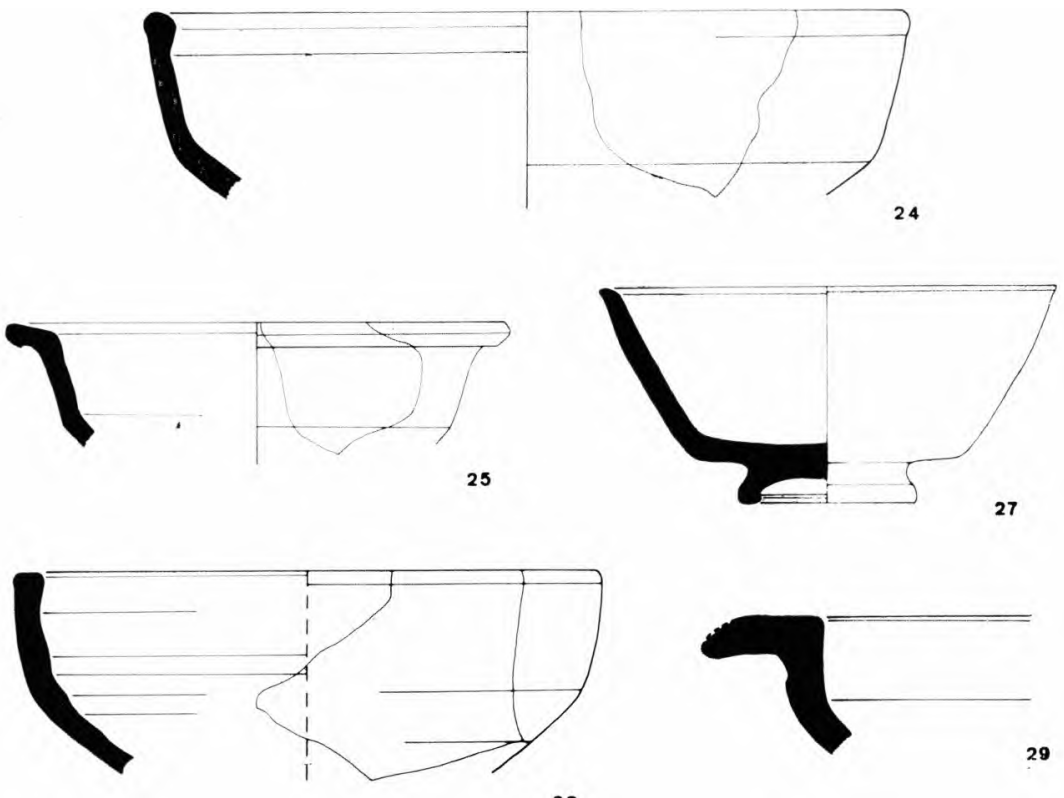

28
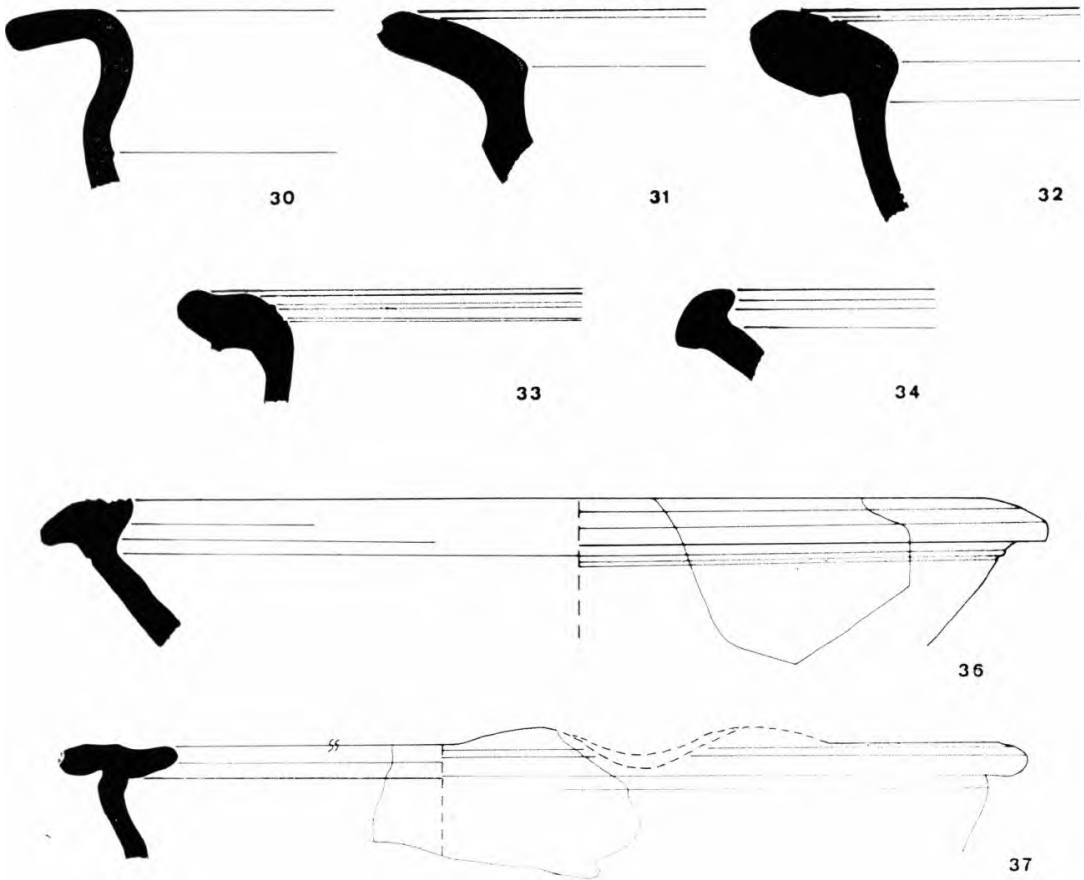

Cerâmica comum: tigelas n.os 24-28; almofarizes n. ${ }^{\text {os }} 29-37$

Esc. 1: 3 
Est. VIII
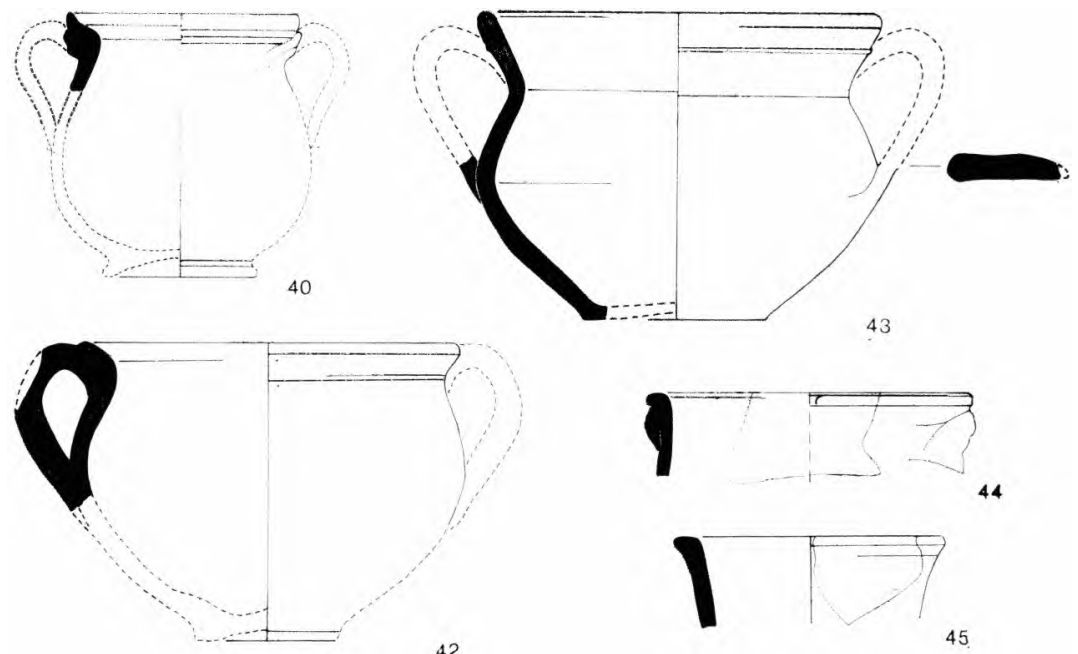

42

45
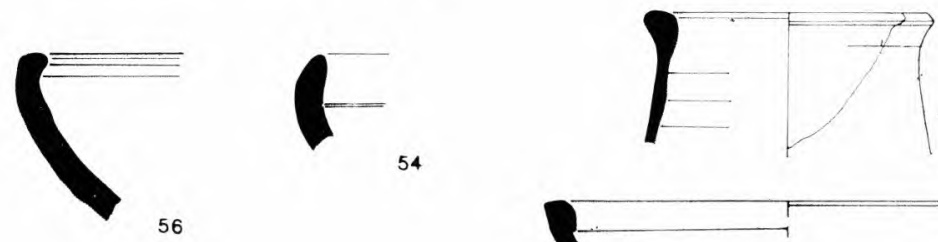

54

46

56
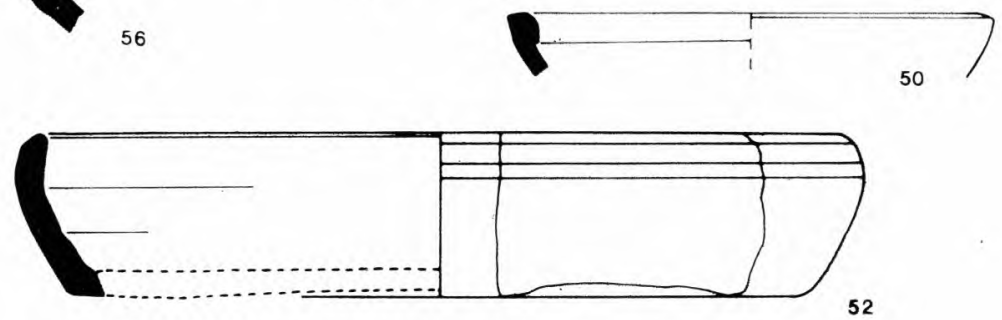

52

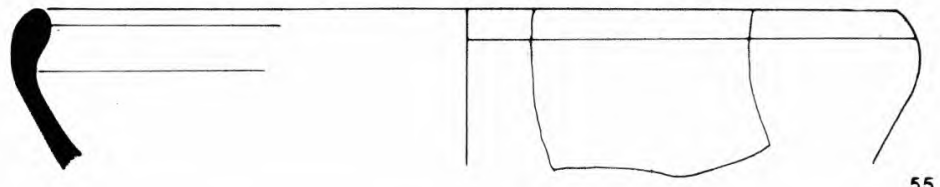

55
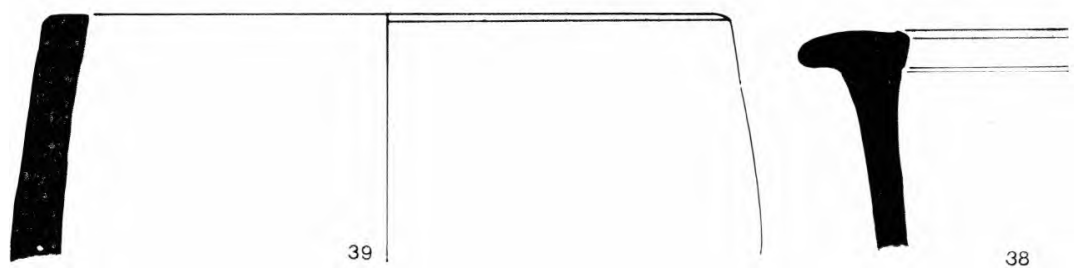

Cerâmica comum: almofarizes n. ${ }^{\text {os }} 38$ e 39 ; púcaros n. ${ }^{\text {ss }} 40-44$; copos n. ${ }^{\circ}$ s 45.46 ; pratos $n .{ }^{\text {os }} 50-56$ Esc. 1:3 
Est. IX
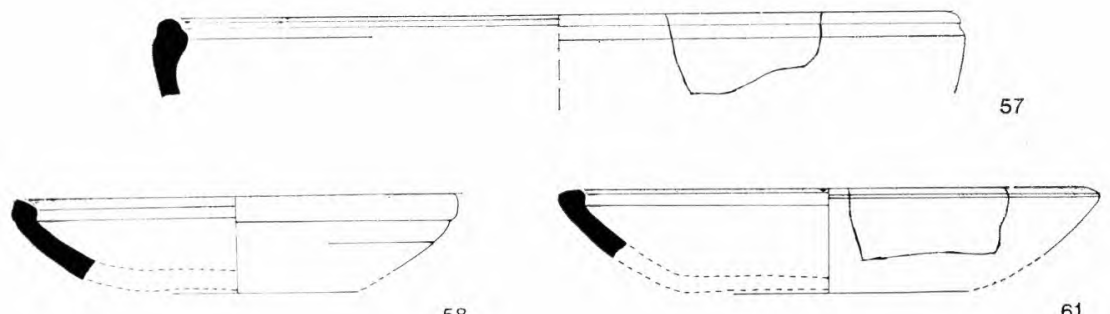

58

61
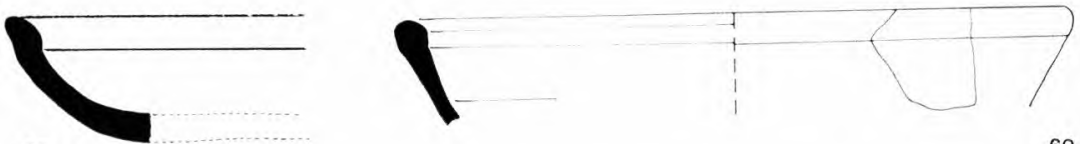

59
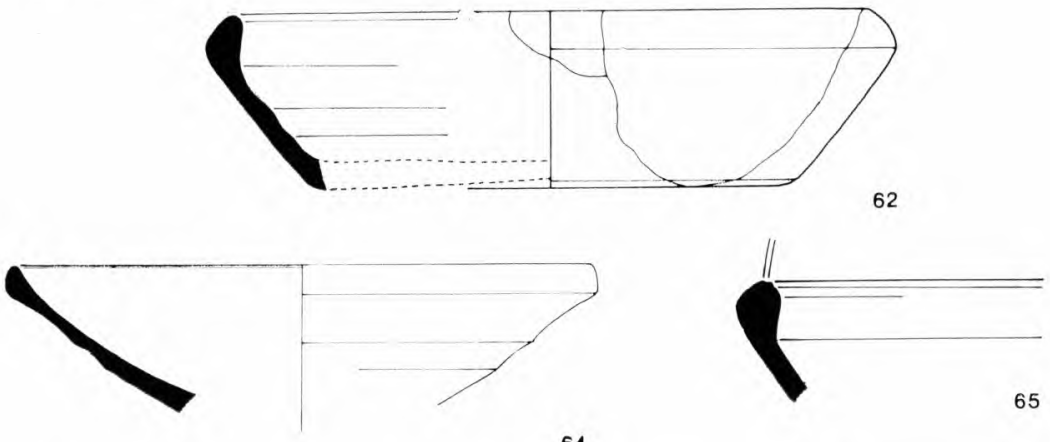

64
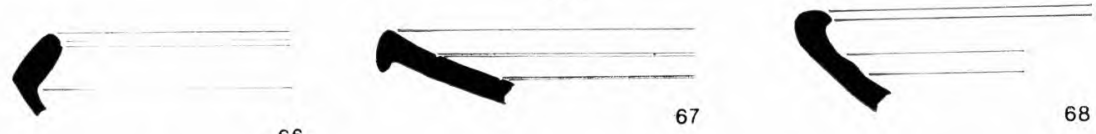

66 67

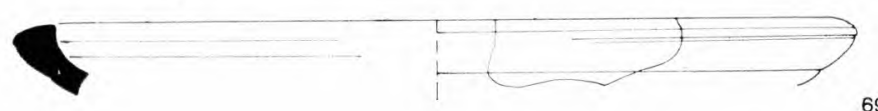

69
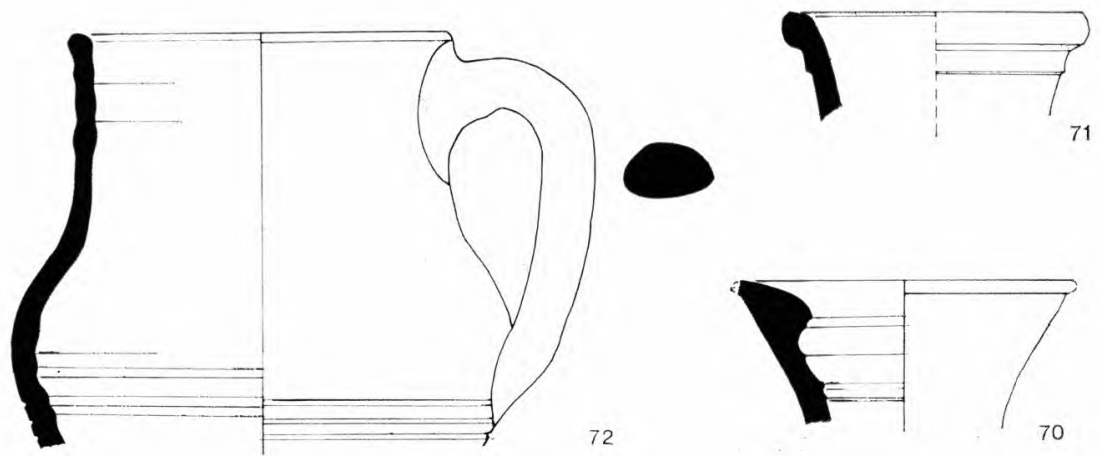

Cerâmica comum: pratos n. ${ }^{\text {os }} 57-69$; bilhas n. ${ }^{\text {os }} 70$ e 71 ; jarro n. ${ }^{\circ} 72$ Esc. $1: 3$ 
Est. X

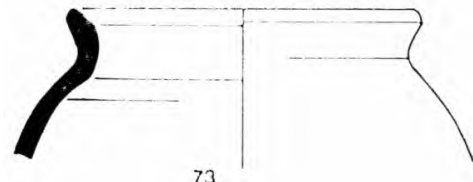

73
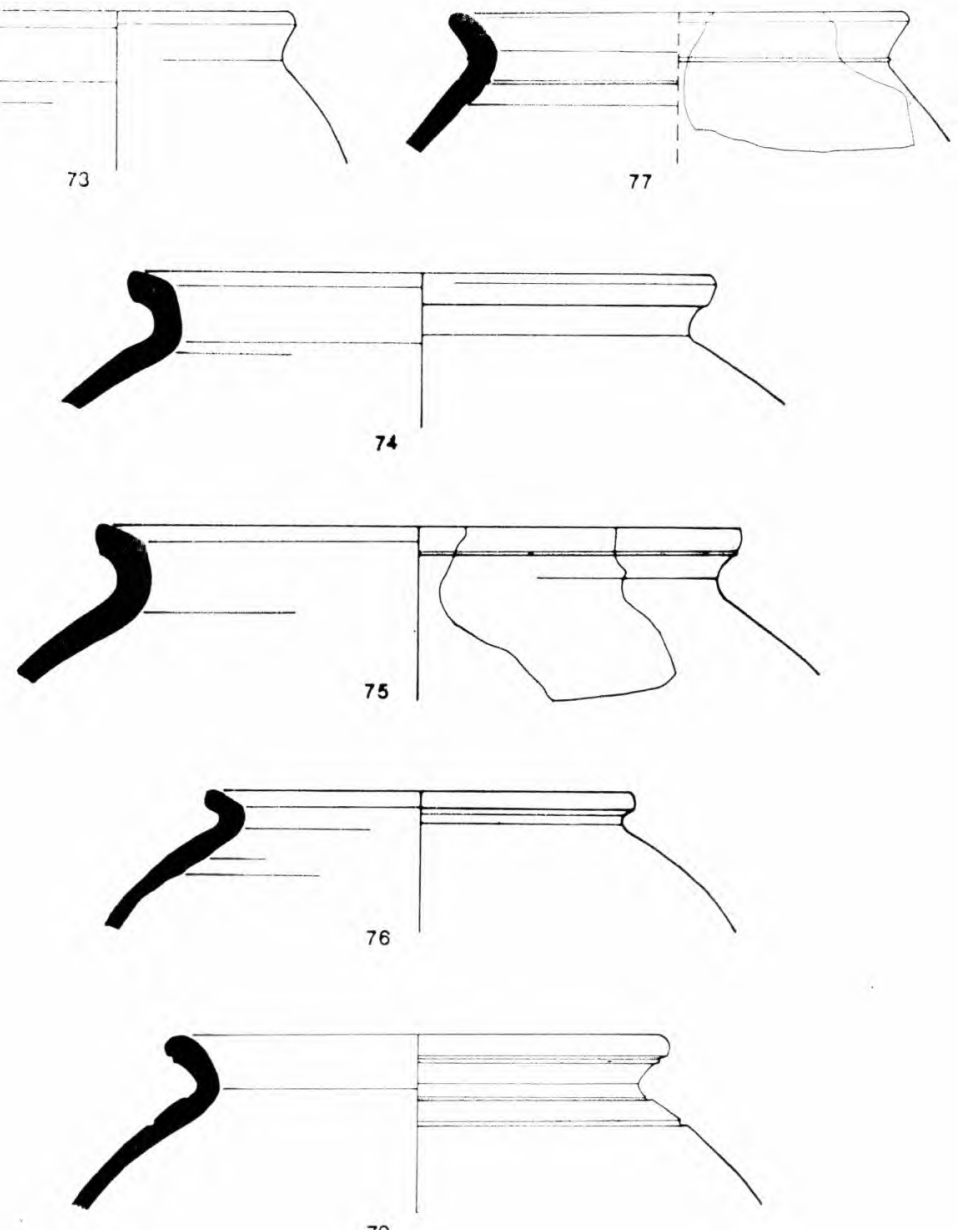

79
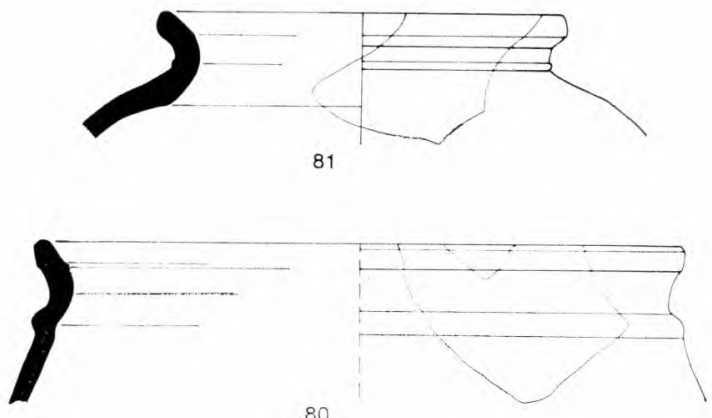

Cerâmica comum: potes n. ${ }^{\text {ss }} 73-81$

Esc. 1: 3 
Est. XI
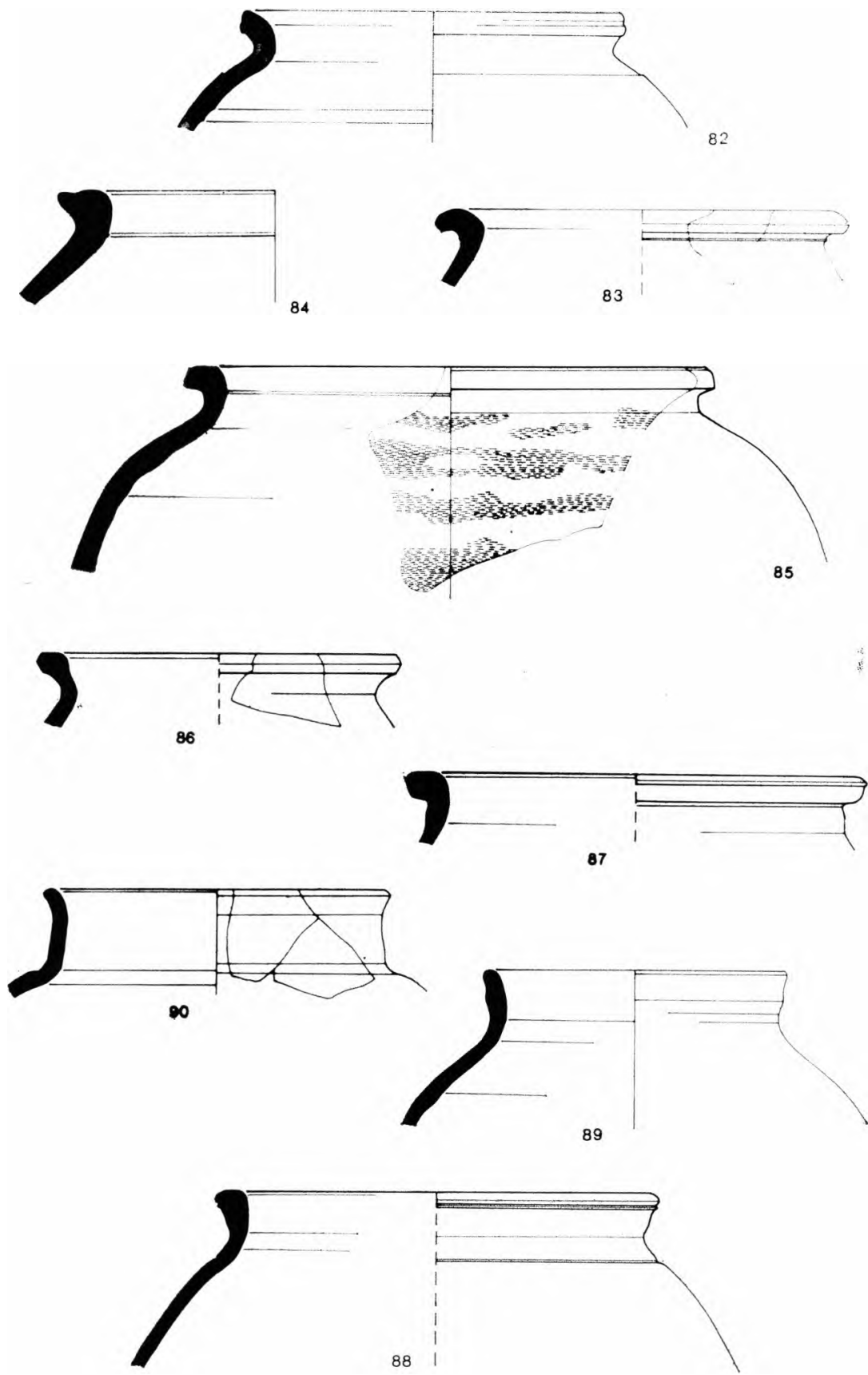

Cerâmica comum: potes n. ${ }^{\text {ss }} 82-90$

Esc. 1: 3 
Est. XII

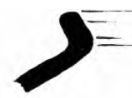

91
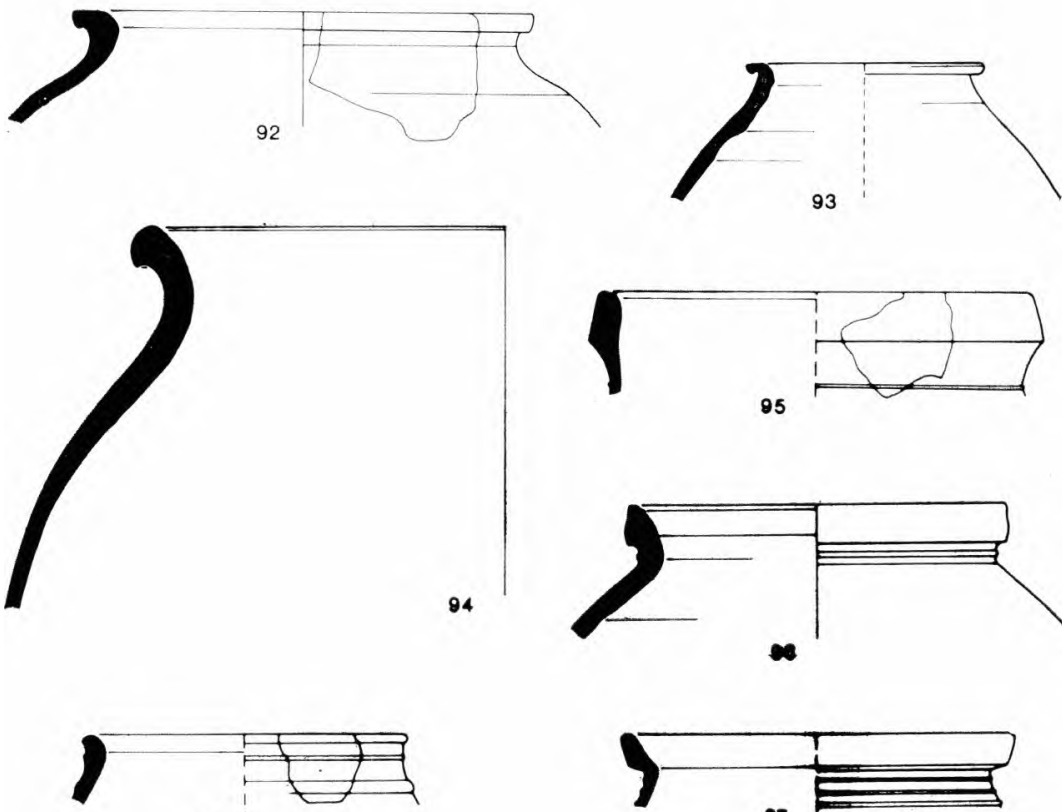

98
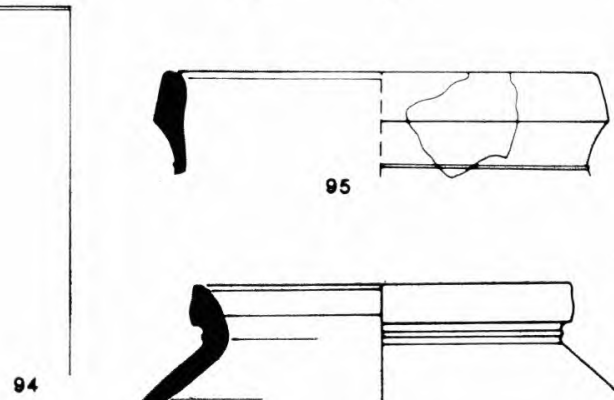

95
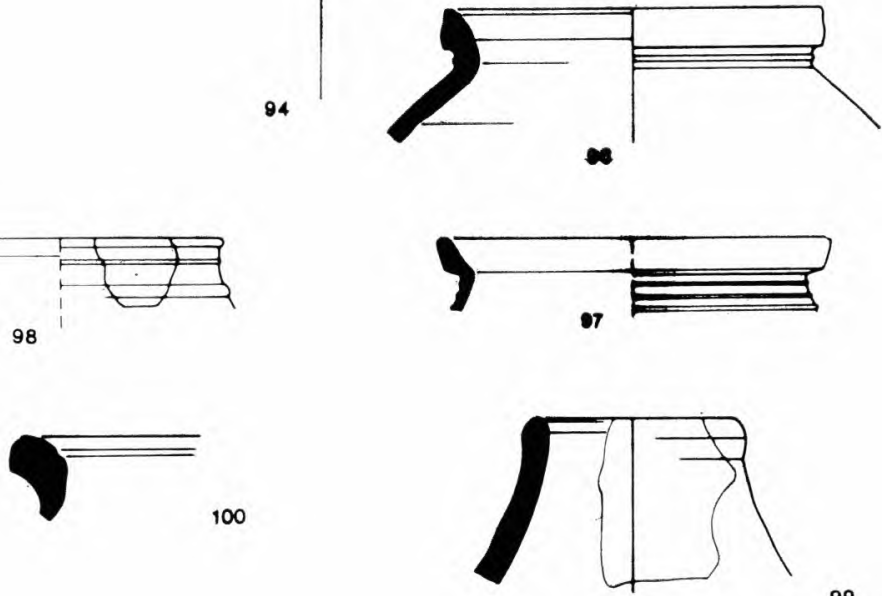

99

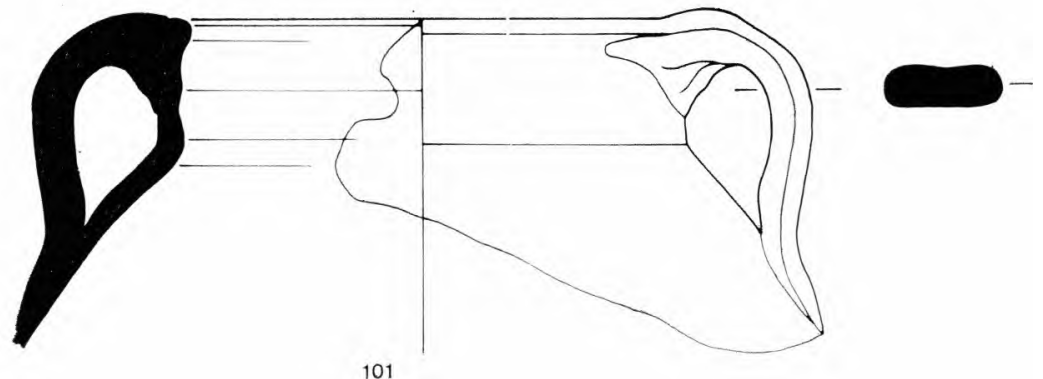

Cerâmica comum : potes n. ${ }^{\text {os }} 91-99$; urnas n. ${ }^{\text {os }} 100$ e 101

Esc. 1: 3 
Est. XIII
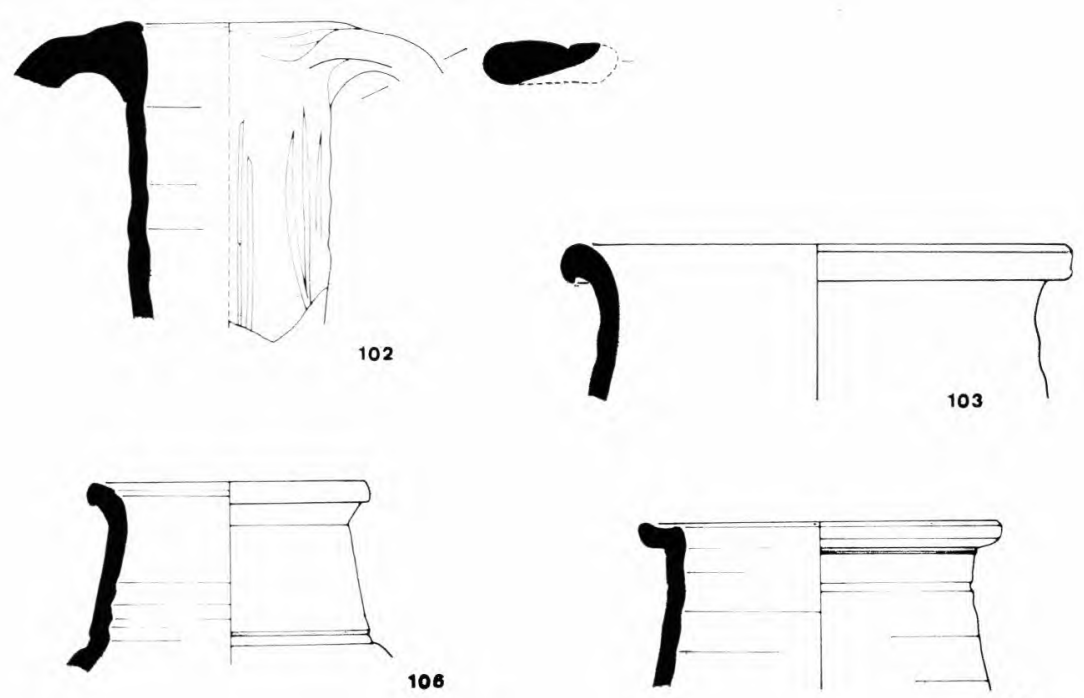

197
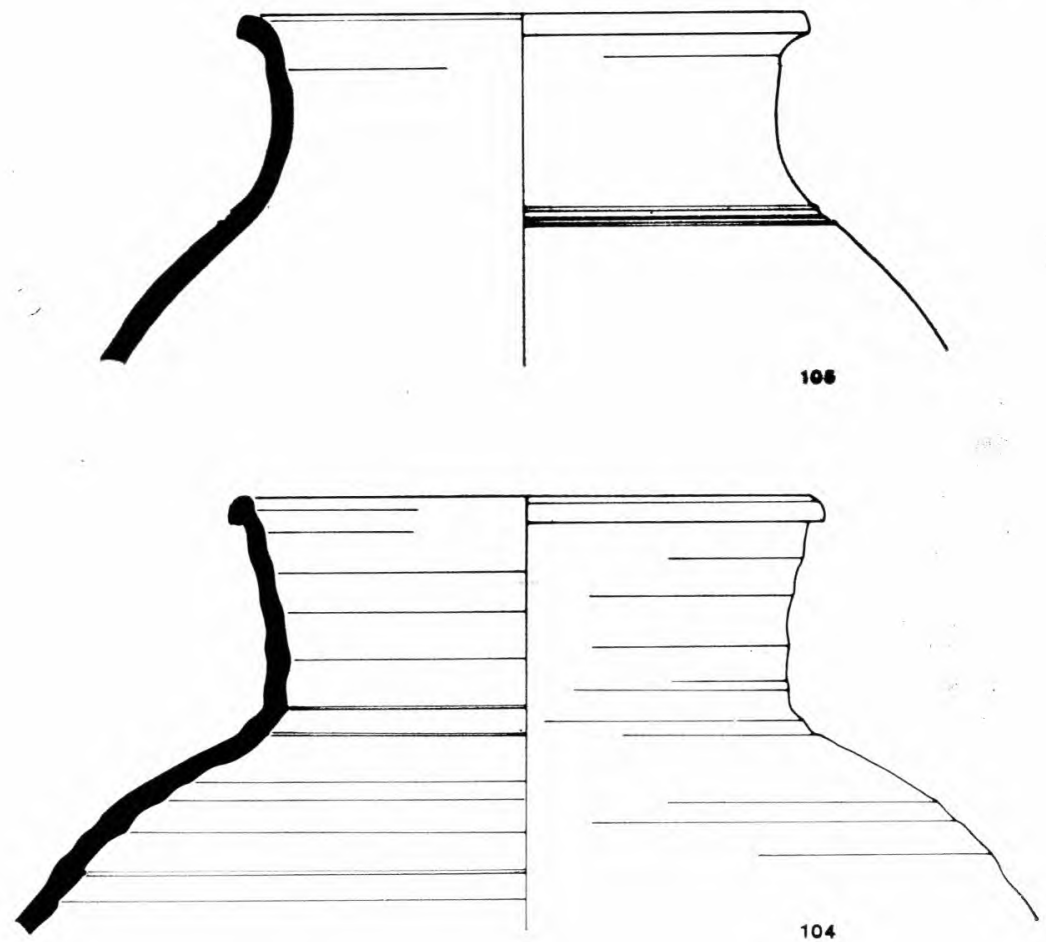

Cerâmica comum. Cântaros n. os 102-107

Esc. 1: 3 


\section{Est. XIY}
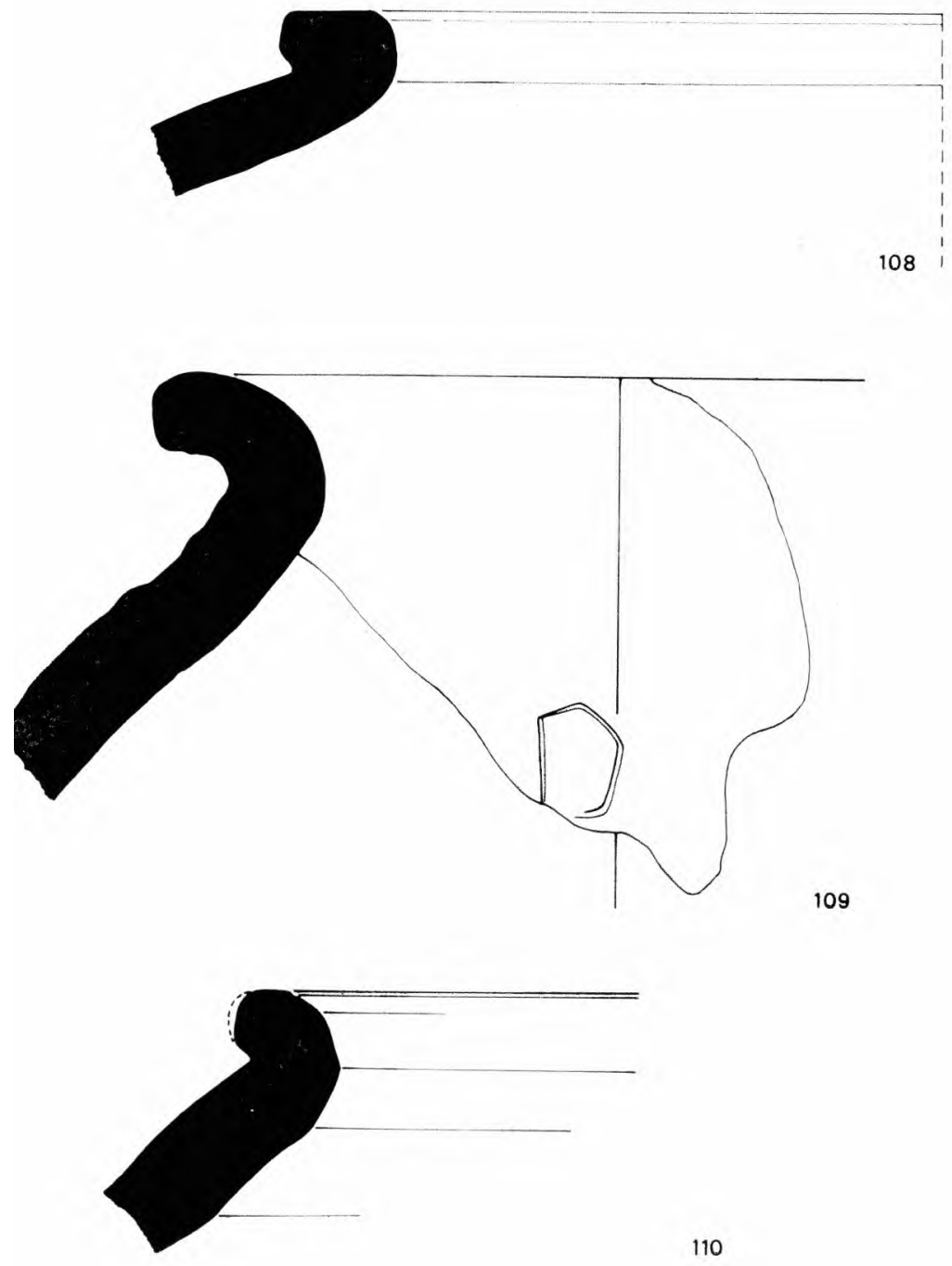

11.1

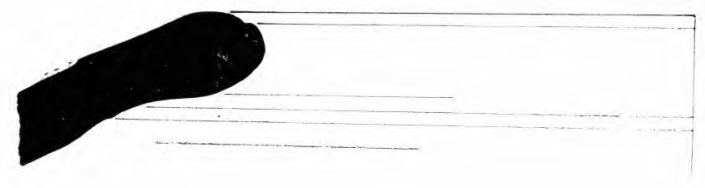

Cerâmica comum: dólios n. ${ }^{\text {os }}$ 108-111

Esc. 1: 3 
Est. XV
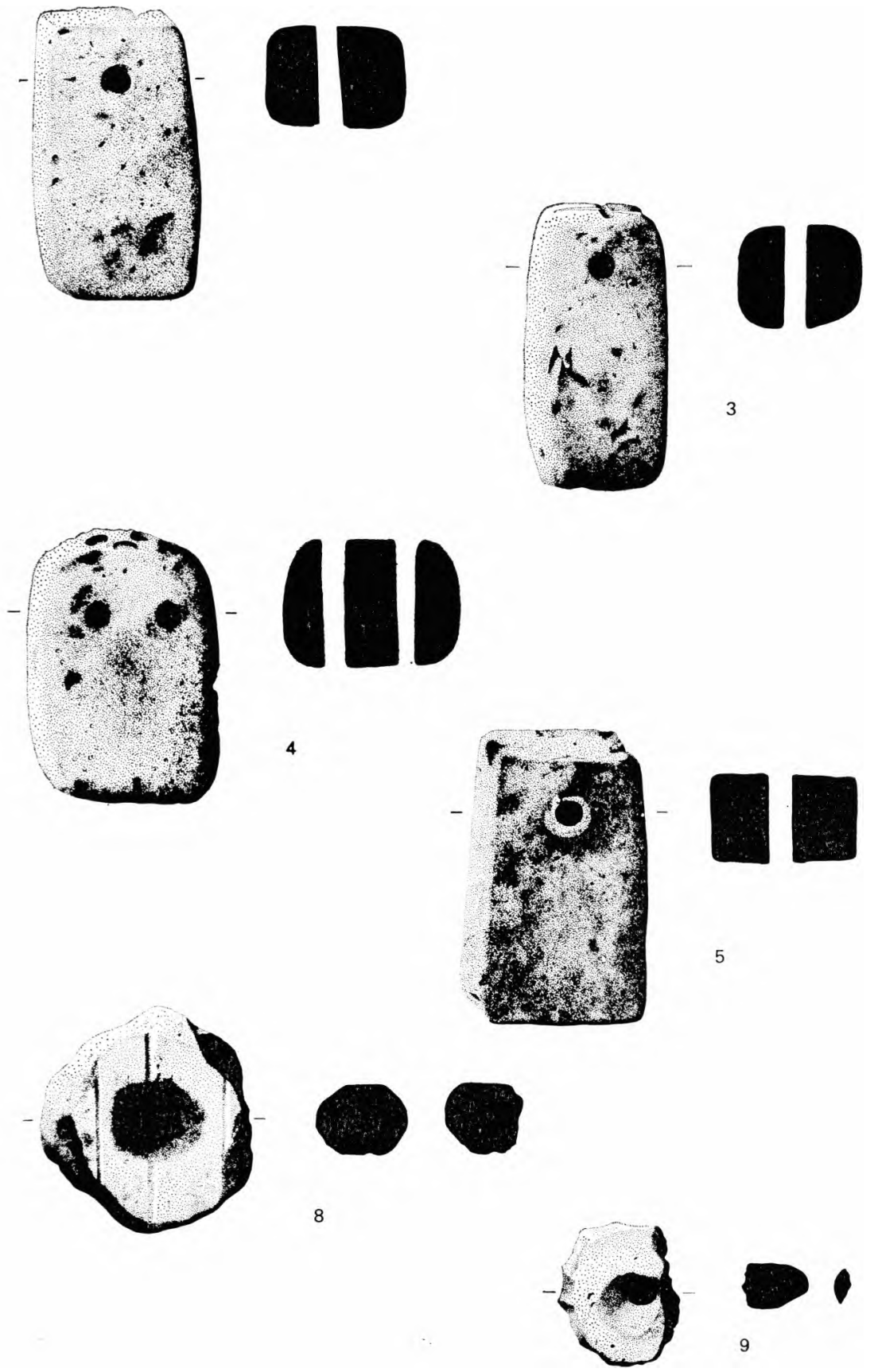

Pesos de tear n. ${ }^{\text {os }} 1$ e $3-5$ e de pesca (?) n. ${ }^{\text {os }} 8$ e 9

Esc. 1: 3 